$$
\text { UNIVERSIDADE DE SÃO PAULO }
$$

FACULDADE DE ECONOMIA, ADMINISTRAÇÃO E CONTABILIDADE DEPARTAMENTO DE ADMINISTRAÇÃO PROGRAMA DE PÓS-GRADUAÇÃO EM ADMINISTRAÇÃO

O ENSINO DE ADMINISTRAÇÃO DA PRODUÇÃO E OPERAÇÕES NA CIDADE DE SÃO PAULO: UM ESTUdO COMPARADO DE PROGRAMAS E LIVROS DIDÁTICOS UTILIZADOS NOS CURSOS DE GRADUAÇÃO EM ADMINISTRAÇÃO DE EMPRESAS

Diógenes de Souza Bido

Orientador: Prof. Dr. Daniel Augusto Moreira

SÃO PAULO 
Prof. Dr. Adolpho José Melfi

Reitor da Universidade de São Paulo

Profa. Dra. Maria Tereza Leme Fleury

Diretora da Faculdade de Economia, Administração e Contabilidade

Prof. Dr. Eduardo Pinheiro Gondim de Vasconcellos

Chefe do Departamento de Administração

Prof. Dr. Isak Kruglianskas

Coordenador do Programa de Pós-Graduação em Administração 


\title{
O ENSINO DE ADMINISTRAÇÃO DA PRODUÇÃO E OPERAÇÕES NA CIDADE DE SÃO PAULO: UM ESTUDO COMPARADO DE PROGRAMAS E LIVROS DIDÁTICOS UTILIZADOS NOS CURSOS DE GRADUAÇÃO EM ADMINISTRAÇÃO DE EMPRESAS
}

Tese apresentada ao Departamento de Administração da Faculdade de Economia, Administração e Contabilidade da Universidade de São Paulo como requisito para a obtenção do título de Doutor em Administração.

Orientador: Prof. Dr. Daniel Augusto Moreira

\author{
SÃo PAULO
}

2004 
FICHA CATALOGRÁFICA

Elaborada pela Seção de Publicações e Divulgação do SBD/FEA/USP

Bido, Diógenes de Souza

O ensino de administração da produção e operações na cidade de São Paulo: um estudo comparado de programas e livros didáticos utilizados nos cursos de graduação em administração de empresas / Diógenes de Souza Bido. -- São Paulo, 2004.

$144 \mathrm{f}$.

Tese (Doutorado) - Universidade de São Paulo, 2004 Bibliografia.

1. Administração - Estudo e ensino 2. Ensino superior 3. Administração da produção I. Faculdade de Economia, Administração e Contabilidade da USP II. Título.

CDD -658.007 


\section{À Naninha.}


A lista com os nomes das pessoas que eu gostaria de citar neste momento ocuparia pelo menos cinco páginas, por isso, me desculpem pelo agradecimento genérico, mas tenham certeza de que o sentimento de gratidão é muito sincero. Assim eu agradeço aos professores da FEA-USP, em especial o Prof. Dr. Daniel Augusto Moreira pela orientação, apoio e amizade durante todos esses anos e que espero contar por muito mais tempo.

A professora Arilda Schmidt Godoy e o professor Sérgio Gozzi também são pessoas que preciso destacar pela orientação dada na qualificação do projeto desta tese.

Tanto no projeto, quanto na etapa final de pesquisa muitas pessoas foram contatadas, agradeço a cada uma delas a colaboração no fornecimento das informações necessárias, em especial a Sra. Vera Lúcia Mourão da FGV-EAESP.

Iniciei o mestrado na FEA em 1995 e até hoje continuo me impressionando com o tratamento que eu recebo de todos os funcionários, e que talvez não tenham se tornado amigos mais próximos apenas pela "correria". Neste momento tenho a oportunidade de deixar meu agradecimento a todas as meninas e meninos do Departamento de Administração, da Secretaria da pós-graduação, do Colegiado, da Biblioteca, da UPD e da Xérox.

A lista de amigos a agradecer, felizmente, é grande. Cito alguns porque sofreram, comemoraram, amadureceram, permaneceram juntos nessa experiência. Muito obrigado pelo apoio: Alceu S. Camargo Jr., César A. Souza, Cláudia S. Goldstein, Eduardo K. Kazuo, Evandir Megliorini, Maria F. F. Ricco, Paulo C. Pagnossin, Perroti P. Pasquale e Rogério A. Profeta.

Finalmente, agradeço à minha família, esposa e amigos do Aikido, da FAC-FITO e da FACESP-UniFECAP, que me incentivaram mesmo quando não sabiam exatamente o que eu estava fazendo. 
"De tempos em tempos professores de administração de negócios, de administração de vendas, de relações industriais, de história dos negócios, de administração financeira me perguntam, ' $O$ que é producão?' Professores de engenharia, de física, de química, de matemática perguntam, 'O que é administração da produção?' Gerentes de produção me perguntam, 'Como você pode ensinar administração da produção?"

Billy E. Goetz (1959, p.7) 


\section{RESUMO}

O ensino de Administração da Produção e Operações (APO) foi investigado em quatro formas complementares: através da revisão da literatura; análise dos conteúdos dos livros didáticos; análise das questões do Exame Nacional de Cursos (Provão) e análise dos programas das disciplinas de APO dos cursos de graduação em Administração de Empresas da FEA-PUC-SP, FEA-USP e FGV-EAESP, que foram consideradas as principais escolas de Administração do município de São Paulo. Quanto aos conteúdos de APO, os resultados convergiram para uma lista de 25 tópicos principais que deveriam ser tratados tanto nos livros didáticos de APO, quanto nos cursos de graduação em Administração de Empresas. Através das respostas aos questionários enviados aos professores, bem como contatos telefônicos, por e-mail e in loco, foram obtidas informações que complementaram a análise do conteúdo de APO, mas também permitiram as seguintes comparações: as três escolas possuem de quatro a cindo disciplinas obrigatórias de APO, totalizando 230 horas no curso, que ainda conta com disciplinas optativas, sendo que a FEA-USP oferece apenas uma disciplina, enquanto a FEA-PUC-SP e a FGV-EAESP oferecem oito; Slack et al. (2002) é o livro mais recomendado para as disciplinas de Administração da Produção e operações, mas para as disciplinas ligadas à Administração de Materiais não há um livro que predomine, além disso, os professores têm complementado seus cursos com apostilas; o método de ensino e o sistema de avaliação nas três escolas possuem vários pontos em comum e o Provão não tem sido utilizado como recurso didático; finalmente, nas três escolas o corpo docente está organizado em áreas ou departamentos, sendo a área de produção uma das menores na FEA-USP e na FGVEAESP. Sendo poucos os professores, deveriam, então, ter alto número de carga horária. Apesar disso, os professores do Departamento de Produção da FGV-EAESP possuem a menor carga horária na graduação, quando comparados com as outras duas escolas. 


\begin{abstract}
Production and Operations Management (POM) teaching has been investigated in four different supporting ways: from literature review, books content, Brazil's National Exam questions, and discipline program analysis, all of them related to POM, and taking place in FEA-USP (Faculdade de Economia e Administração - Business Economics College of University of São Paulo) Business Management Courses, PUC-SP (Catholic University of São Paulo), and FGV-EAESP, most renowned Business Schools in São Paulo. Results concerning POM drove to 25 main listed topics which should be referred not only in POM school books, but also in Management graduation courses. Upon answers to the questions sent to professors, phone contacts, e-mails and locals, some information was collected, which led to the following comparison levels: the mentioned schools above have 4 or 5 primary course disciplines related to POM, totalizing 230 hours, and there are still free choice program students. FEA-USP offers just one disicipline, while FEA-PUC-SP, and FGV-EAESP offer eight. Slack et al. (2002) is the most recomended book concerning POM disciplines, but for the ones related to Material Management there is no such prevailing book. Besides, professors have been meeting their courses content goal using their own notes. Teaching methods, and grading systems in those schools have common views and the National Exam has not been used as a reference or a pattern. Finally, the faculty in those three schools is divided into areas or departments. The Production area is one of the smallest in FEA-USP and FGV-EAESP, and as a result of it, FGV-EAESP Production Department professors have the smallest number of classes in graduation courses, compared to the other two schools, though as they are so few, those teachers were expected to have great numbers of classes.
\end{abstract}




\section{LISTA DE FIGURAS}

Figura 1: Distribuição das IES's com cursos de Administração em 2002 ..........................9

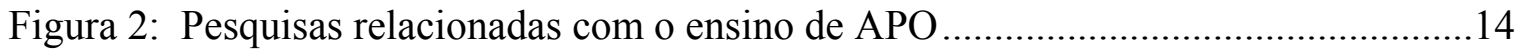

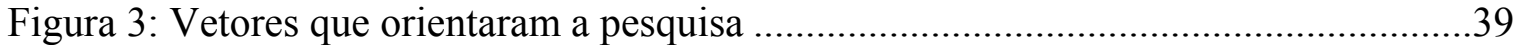

Figura 4: Freqüência com que os tópicos de APO aparecem nos livros didáticos............64

\section{LISTA DE TABELAS}

Tabela 1: A evolução dos cursos de Administração no Brasil .............................................8

Tabela 2: Distribuição por ano de edição dos livros de Administração da Produção recomendados na "Biblioteca básica"

Tabela 3: Distribuição por ano de edição dos livros de Recursos Materiais e Patrimoniais recomendados na "Biblioteca básica".

Tabela 4: Evolução da quantidade de questões do Provão de Administração por matéria 72

Tabela 5: Titulação e regime de trabalho dos docentes das escolas pesquisadas................96

Tabela 6: Distribuição dos professores nas áreas do Departamento de Administração da

FEA-PUC-SP em 2004

Tabela 7: Distribuição dos professores nas áreas do Departamento de Administração da FEA-USP em 2004

Tabela 8: Distribuição dos professores nos departamentos da FGV-EAESP em 2004 ...100

Tabela 9: Comparação quantitativa do corpo docente e disciplinas de APO - 2004 ......102

\section{LISTA DE QUADROS}

Quadro 1: Evolução mais recente da Administração da Produção e Operações e da "agenda" de pesquisas nesta área

Quadro 2: Instituições de Ensino Superior com oito "A" no Provão

Quadro 3: Questões e fontes de informação sobre os conteúdos, metodologias de ensino e

organização do corpo docente.

Quadro 4: Comparação entre o capítulo 21 - Desafio da produção - da $1^{\mathrm{a}}$ e $2^{\mathrm{a}}$ edição do

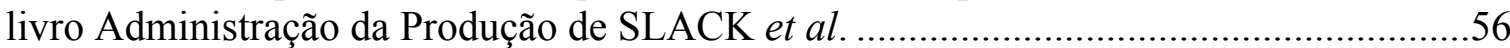

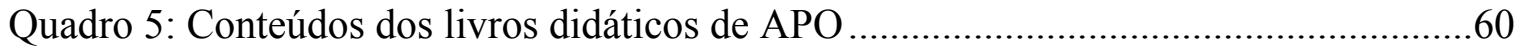

Quadro 6: Abrangência de conteúdo dos livros didáticos analisados ................................66

Quadro 7: Estrutura e recursos de aprendizagem dos livros didáticos de APO .................67

Quadro 8: Conteúdos de APO no ENC de 2001 a 2003 .......................................................74

Quadro 9: Disciplinas de APO obrigatórias no curso de Administração ............................83 


\section{SUMÁRIO}

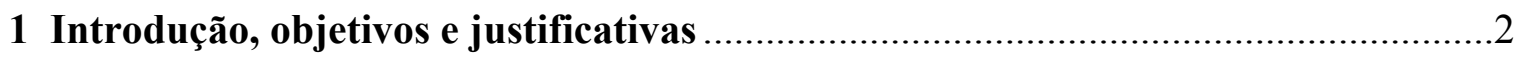

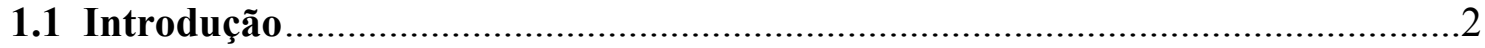

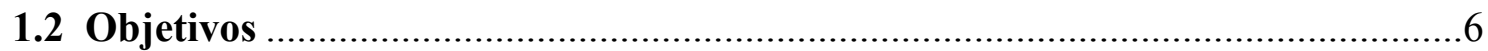

1.2.1 Geral

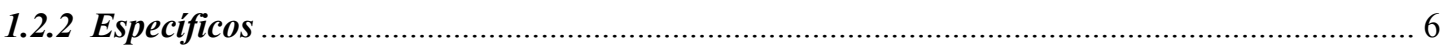

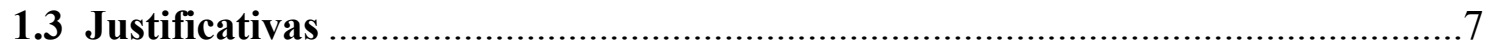

2 O estado-da-arte das pesquisas sobre o ensino de APO nos cursos de

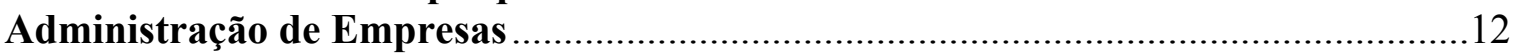

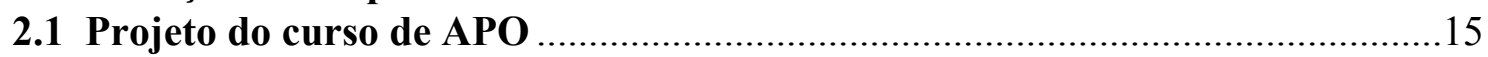

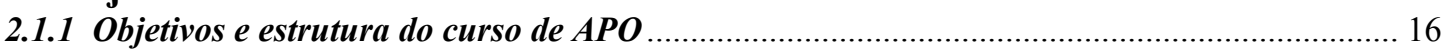

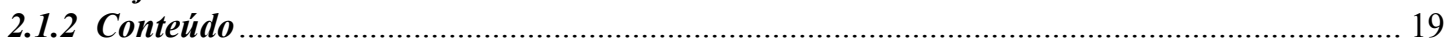

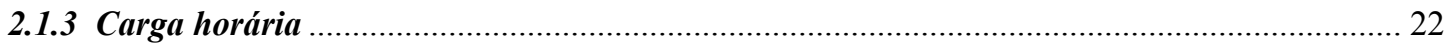

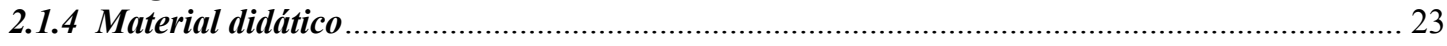

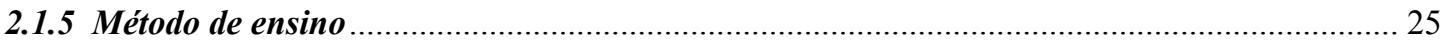

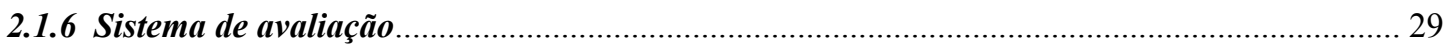

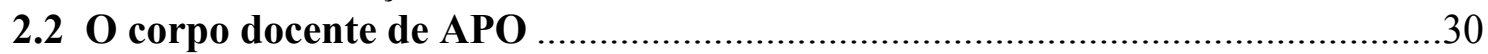

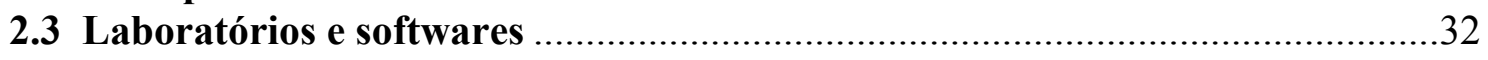

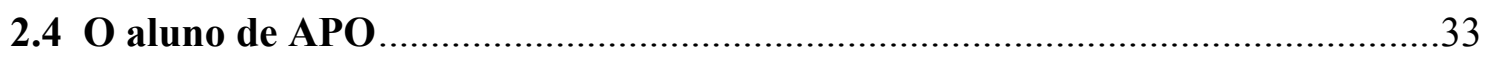

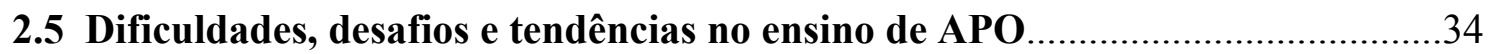

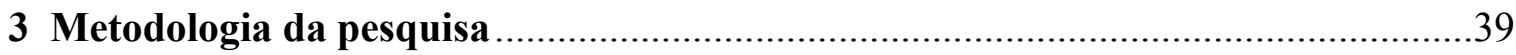

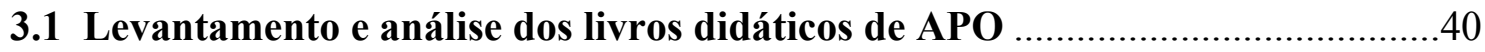

3.2 Levantamento e análise do Provão de Administração de Empresas ...................42

3.3 Levantamento e análise dos cursos de Administração de Empresas..................43

3.4 Limitações, validade interna e externa.......................................................... 47

4 O conteúdo de APO e os recursos de aprendizagem do ponto de vista dos livros

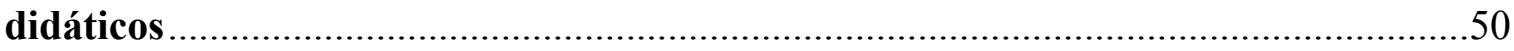

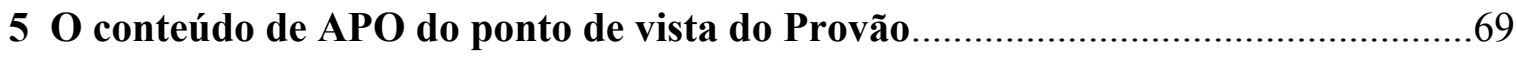

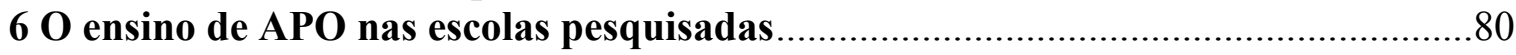

6.1 APO na estrutura curricular do curso de Administração................................ 81

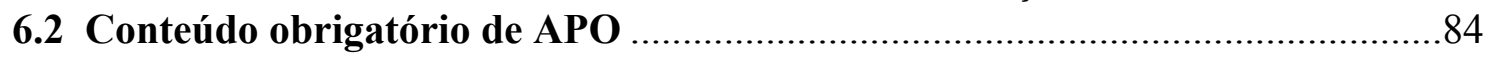

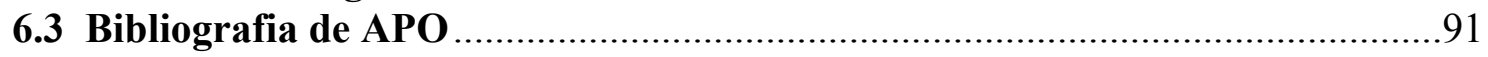

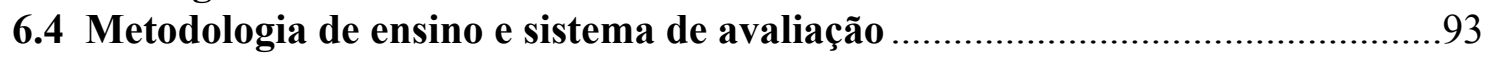

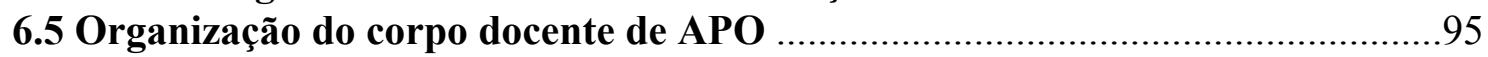

6.5.1 Organização do corpo docente de APO na FEA-PUC-SP ............................................... 97

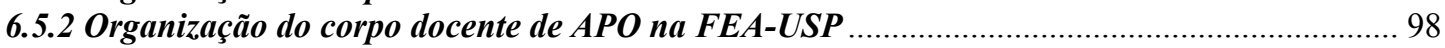

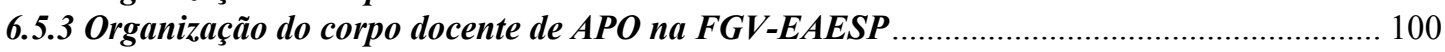

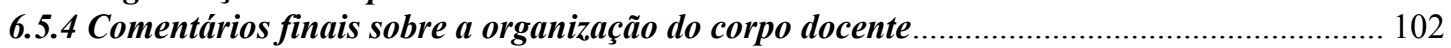

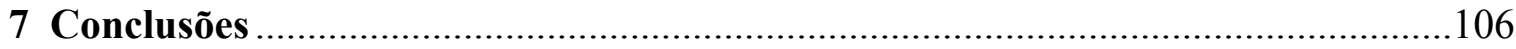

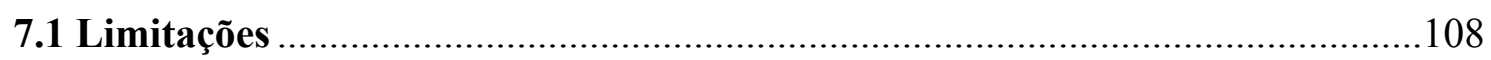

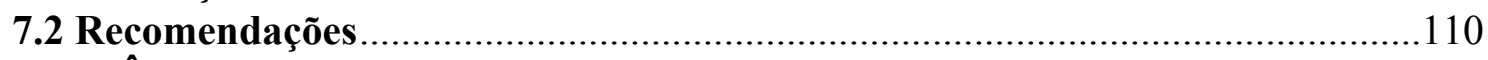

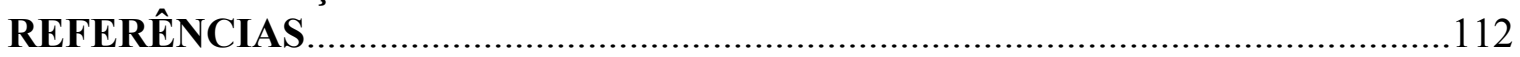

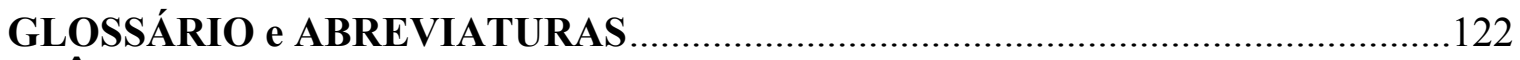

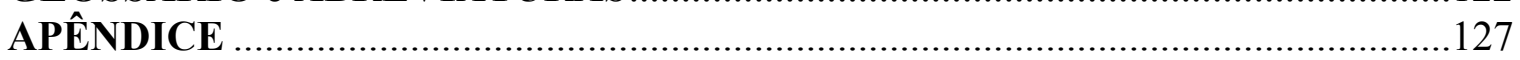

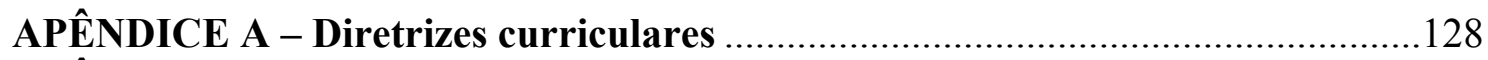

APÊNDICE B - E-mail enviado aos professores de APO na graduação ................130

APÊNDICE C - Credibilidade do pesquisador ..................................................132 
CAPÍTULO 1

Introdução, objetivos e justificativas 


\section{Introdução, objetivos e justificativas}

\subsection{Introdução}

A baixa competitividade dos Estados Unidos em manufatura na década de 1980 incentivou a execução de várias pesquisas para avaliar quais eram as necessidades das indústrias e questionar até que ponto as escolas de nível superior estavam provendo o conhecimento e habilidades necessárias aos seus alunos (BAH, 1989; RAISZADEH; ETTIKIN, 1989; BERRY; LANCASTER, 1992; TAJ; HORMOZI; MIRSHAB, 1996).

Pesquisa semelhante às americanas foi feita por Pilão (1987) com profissionais da Grande São Paulo, mas pode-se observar que na última década houve poucas pesquisas sobre o ensino de Administração da Produção no Brasil. Wood Jr. (2000; 2001) destacou que os artigos publicados, geralmente, estão atrasados em relação à prática gerencial e que o avanço da indústria de serviços em relação às atividades de manufatura causou um impacto sobre as escolas de Administração, onde os cursos tradicionais de Administração da Produção são sub-valorizados pelos alunos e taxados como anacrônicos.

No quadro 1 são apresentados os tópicos de Administração da Produção e Operações (APO) que tiveram maior destaque (agenda) nas últimas cinco décadas em função de algumas características contextuais. Do ponto de vista do ensino de APO é interessante observar que os tópicos mais novos praticamente não eliminaram ou substituíram os mais antigos, que continuam a fazer parte dos livros didáticos mais atuais de APO. 
Quadro 1: Evolução mais recente da Administração da Produção e Operações e da "agenda" de pesquisas nesta área

\begin{tabular}{|c|c|c|c|c|}
\hline & \multirow{2}{*}{$1957-1973$} & & & \\
\hline & & $1974-1994$ & $1995-1999$ & $2000-2003$ \\
\hline
\end{tabular}

Fonte: Adaptado por Wood Jr. (2000; 2001) a partir de Machline (1994) e complementado pelo autor com os dados de Bennet (1999, apud WOOD JR., 2001), Silveira (2003) e Machuca (2003). 
O ensino de Administração, de modo geral, tem sido um tema de maior interesse dos pesquisadores nos últimos anos, como Carboni (2002), Takei (2002), Tcheou (2002) e Putvinskis (2001). No Brasil, a Associação Nacional dos Programas de Pós-Graduação em Administração (ANPAD) promove, anualmente, o Encontro Nacional da ANPAD (ENANPAD), que põe em contato pesquisadores de diferentes interesses, facilitando o intercâmbio entre alunos e docentes e fomentando pesquisas e publicação. Até o ano 2000 ainda não havia uma área temática específica para as pesquisas relativas ao "Ensino e pesquisa em administração", e desde 2001 têm sido publicados 22 trabalhos por ano nesta área.

Outro evento importante, no contexto nacional, é o Simpósio de Administração da Produção, Logística e Operações Internacionais (SIMPOI), que é promovido desde 1998 pelo Departamento de Administração da Produção e Operações da Escola de Administração de Empresas de São Paulo da Fundação Getulio Vargas. E em 2003 foi realizada a sua sexta versão, contando com oito áreas temáticas. O Ensino de Administração da Produção e Operações é uma das 17 sub-áreas $^{1}$ da área temática Visão Geral da Área de Operações.

Sendo uma área em evolução, pode-se afirmar que o ensino de APO está longe de ser uma questão respondida. Se for considerado apenas o conteúdo que deveria fazer parte dos cursos de APO, já resulta um bom debate. Em primeiro lugar porque o conteúdo deve ser não apenas atual, mas também procurar atender as necessidades futuras de conhecimento dos alunos, incluindo a discussão sobre as novas tecnologias e metodologias de administração, e, em segundo, porque cada vez mais está evidente a necessidade de integração entre as disciplinas do curso, buscando trazer para a sala de aula exemplos da vida real.

\footnotetext{
1 Nos anos de 1998 e 1999 não havia uma área temática específica, ou sub-área, para o Ensino de APO, mas em 1999 foi publicado um artigo relacionado a este tema: "O uso de simulação para a educação $e$ treinamento em gestão com sistemas ERP" de autoria de Henrique Luiz Corrêa. No ano 2000 foram publicados oito trabalhos e no ano de 2001 cinco, sendo três sobre o uso da simulação no ensino de APO e dois sobre o ensino à distância. Finalmente, no ano 2002 foram publicados apenas três trabalhos, sendo dois deles ligados ao ensino à distância (SIMPOI, 1998; SIMPOI 1999; SIMPOI, 2000; SIMPOI, 2001; SIMPOI, 2002).
} 
Essa demanda por atualização é inerente a qualquer disciplina profissionalizante do curso de Administração de Empresas, e nas últimas duas décadas algumas questões têm sido refeitas nas pesquisas americanas e européias, tais como, quanto deve ser tratado de técnicas e conceitos, serviços e manufatura, foco operacional e estratégico?

A profundidade e a amplitude dos tópicos abordados num curso de APO também têm sido motivo de discussão, não só pela carga horária atribuída às disciplinas de APO ou o curso em que as disciplinas estão inseridas (é esperado que as disciplinas de APO num curso de pós-graduação ou MBA envolvam mais questões estratégicas que um curso em nível de graduação), mas também porque alguns alunos de Administração e até professores consideram APO como uma área para engenheiros, chegando a ponto de se questionar a necessidade de se incluir APO num curso de Administração.

Pilão (1987, p. 2 - 30) reconheceu a dificuldade para se delimitar um campo de atuação para o administrador e o engenheiro industrial ou de produção, afirmando que:

\footnotetext{
Sem que haja uma fronteira clara para sua atuação, parece-nos que o engenheiro industrial, ou engenheiro de produção seja também, pela sua própria formação, a pessoa mais adequada para mensurar e extrair das máquinas, dos métodos e dos sistemas, a maior produtividade possível. [...] Porém, se defendermos que administrar é algo muito mais amplo, que envolve não só restrições quantitativas ponderáveis ou não, mas também qualitativas (como por exemplo, de relações humanas, de conjuntura social e econômica, etc.), então diríamos que as técnicas de pesquisa operacional, supra citadas, constituem-se num suporte ou ferramental utilizado para a tomada de decisão, e seríamos obrigados a reconhecer, pelo menos à primeira vista, que o administrador talvez seja o profissional mais qualificado para exercer tal função[...].
}

Uma "resposta-padrão" para esse questionamento é a própria diretriz curricular do curso de Administração (BRASIL on line, 2003b), que exige o conteúdo de APO. Outra resposta é dada por Pilão (1987, p. 2) da seguinte forma:

A par de ser esta área um significativo mercado de trabalho, sabe-se também que gerir uma empresa industrial implica tomar grandes decisões com base na área fabril. Isto faz com que os administradores de outras áreas, que não a produtiva, também tenham absoluta necessidade de conhecer e desenvolver seus estudos neste importante segmento da empresa. 


\subsection{Objetivos}

Levando em conta o que foi apresentado até este ponto e a escassez de pesquisas nacionais, havia, por um lado, a intenção de pesquisar o ensino de APO nas principais escolas de Administração da cidade de São Paulo, e, por outro, o conhecimento de algumas diferenças significativas entre as características e metodologias adotadas pela Faculdade de Economia, Administração e Contabilidade da Universidade de São Paulo (FEA-USP), Escola de Administração de Empresas de São Paulo da Fundação Getúlio Vargas (FGVEAESP) e a Faculdade de Economia, Administração, Contabilidade e Atuária da Pontifícia Universidade Católica (FEA-PUC-SP) (essa escolha é explicada no capítulo 3), como o número de professores no departamento de produção e a série em que são ministradas as disciplinas de APO, o que motivou o início desta pesquisa com os objetivos dados a seguir.

\subsubsection{Geral}

Comparar o ensino de APO nas três principais escolas de Administração da cidade de São Paulo, quanto aos conteúdos, bibliografia, metodologia de ensino, sistema de avaliação e organização do corpo docente.

\subsubsection{Específicos}

Além do objetivo geral foram estabelecidos outros objetivos específicos com o intuito de estruturar a pesquisa e também obter informações de outras fontes que pudessem ser trianguladas com os resultados obtidos nas escolas, aumentando a confiabilidade de nossas conclusões:

a) Identificar o estado-da-arte das pesquisas sobre o ensino de APO;

b) Analisar os conteúdos dos principais livros didáticos nacionais e americanos;

c) Analisar os conteúdos de APO do ponto de vista do Provão (ENC - Exame Nacional de Cursos). 


\subsection{Justificativas}

A área de Administração reúne, atualmente, o maior número de cursos de graduação, alunos matriculados e professores envolvidos no ensino de graduação. São aproximadamente 1180 IES's com cursos de graduação em Administração no Brasil, nas quais estudam 450 mil alunos (KREUZ on line, 2003).

Os cursos de Administração de Empresas têm sido ministrados nos mais variados formatos: matutino ou noturno, anual ou semestral, com duração de quatro ou cinco anos, presencial, seqüencial e até à distância ${ }^{2}$, com ênfase em muitos campos, as ditas especialidades ou habilitações.

No período de 1996 a 2001 o número de cursos de graduação em Administração duplicou, enquanto o conjunto dos cursos de graduação presenciais no Brasil teve um aumento de cerca de $80 \%$. Apesar disso, podemos observar na tabela 1 que a proporção de concluintes do curso de Administração tem se mantido praticamente constante, com uma média de $11,2 \%$ do total de concluintes em cursos presenciais e em 2001 esse número só era superado pelos cursos de Direito, que formaram 48.270 alunos em seus 505 cursos.

\footnotetext{
2 A Faculdade de Administração de Brasília, mantida pela Associação Internacional de Educação Continuada (AIEC), já conta com um curso de bacharel em Administração com a habilitação Administração Geral, na modalidade à distância, autorizado pelo Ministério da Educação (AIEC on line, 2004).
} 
Tabela 1: A evolução dos cursos de Administração no Brasil

\begin{tabular}{l|c|c|c|c|c|c|c}
\hline \multicolumn{1}{c|}{ Ano } & $\mathbf{1 9 9 6}^{\mathbf{3}}$ & $\mathbf{1 9 9 7}^{\mathbf{4}}$ & $\mathbf{1 9 9 8}$ & $\mathbf{1 9 9 9}$ & $\mathbf{2 0 0 0}$ & $\mathbf{2 0 0 1}$ & $\begin{array}{c}\text { Aumento } \\
\text { de 1996 } \\
\mathbf{\text { Total 2001 }}\end{array}$ \\
\hline $\begin{array}{l}\text { Cursos } \\
\text { presenciais }\end{array}$ & 6.644 & 6.132 & 6950 & 8.878 & 10.585 & 12.155 & $82,9 \%$ \\
\hline $\begin{array}{l}\text { Cursos de } \\
\text { Administração }\end{array}$ & $\begin{array}{c}503 \\
(7,6 \%)\end{array}$ & $\begin{array}{c}461 \\
(7,5 \%)\end{array}$ & $\begin{array}{c}549 \\
(7,9 \%)\end{array}$ & $\begin{array}{c}776 \\
(8,7 \%)\end{array}$ & $\begin{array}{c}793 \\
(7,5 \%)\end{array}$ & $\begin{array}{c}1.009 \\
(8,3 \%)\end{array}$ & $\begin{array}{c}100,6 \% \\
(101 / \mathrm{ano})\end{array}$ \\
\hline $\begin{array}{l}\text { Concluintes } \\
\text { em cursos } \\
\text { presenciais }\end{array}$ & 260.224 & 274.384 & 300.761 & 324.734 & 352.305 & 395.988 & $52,2 \%$ \\
\hline $\begin{array}{l}\text { Concluintes } \\
\text { dos cursos de } \\
\text { Administração }\end{array}$ & $\begin{array}{c}29.015 \\
(11,2 \%)\end{array}$ & $\begin{array}{c}31.630 \\
(11,5 \%)\end{array}$ & $\begin{array}{c}34.025 \\
(11,3 \%)\end{array}$ & $\begin{array}{c}35.658 \\
(11,0 \%)\end{array}$ & $\begin{array}{c}39.147 \\
(11,1 \%)\end{array}$ & $\begin{array}{c}43.320 \\
(11,0 \%)\end{array}$ & $\begin{array}{c}49,3 \% \\
(2861 / \mathrm{ano})\end{array}$ \\
\hline
\end{tabular}

Fonte: Tabela preparada pelo autor com os dados disponíveis em INEP (on line, 2004a).

Quanto à distribuição geográfica, observa-se na figura 1 que $12 \%$ dos cursos de Administração do Brasil estão localizados na cidade de São Paulo e que o Estado de São Paulo responde por $38 \%$ destes cursos.

3 Para os dados do período de 1996 a 1998 foram considerados os cursos de "Administração", não foi incluído o curso de Administração de RH, nem o de Administração Rural. Para os dados do período de 1999 e 2000 foram considerados os cursos de "Gerenciamento e Administração", que incluem: Administração, Administração de agronegócios, Administração de cooperativas, Administração de empresas, Administração de recursos humanos, Administração de sistemas de informações, Administração dos serviços de saúde, Administração em análise de sistemas / informática, Administração em comércio exterior, Administração em marketing, Administração em turismo, Administração financeira, Administração hospitalar, Administração hoteleira, Administração industrial, Administração pública, Administração rural.

4 O objetivo desta tabela é apresentar, em linhas gerais, a evolução dos cursos de graduação em Administração, comparativamente ao total de cursos presenciais, por isso não se investigou as causas que poderiam ter levado a uma queda nos números dos cursos em 1997. 


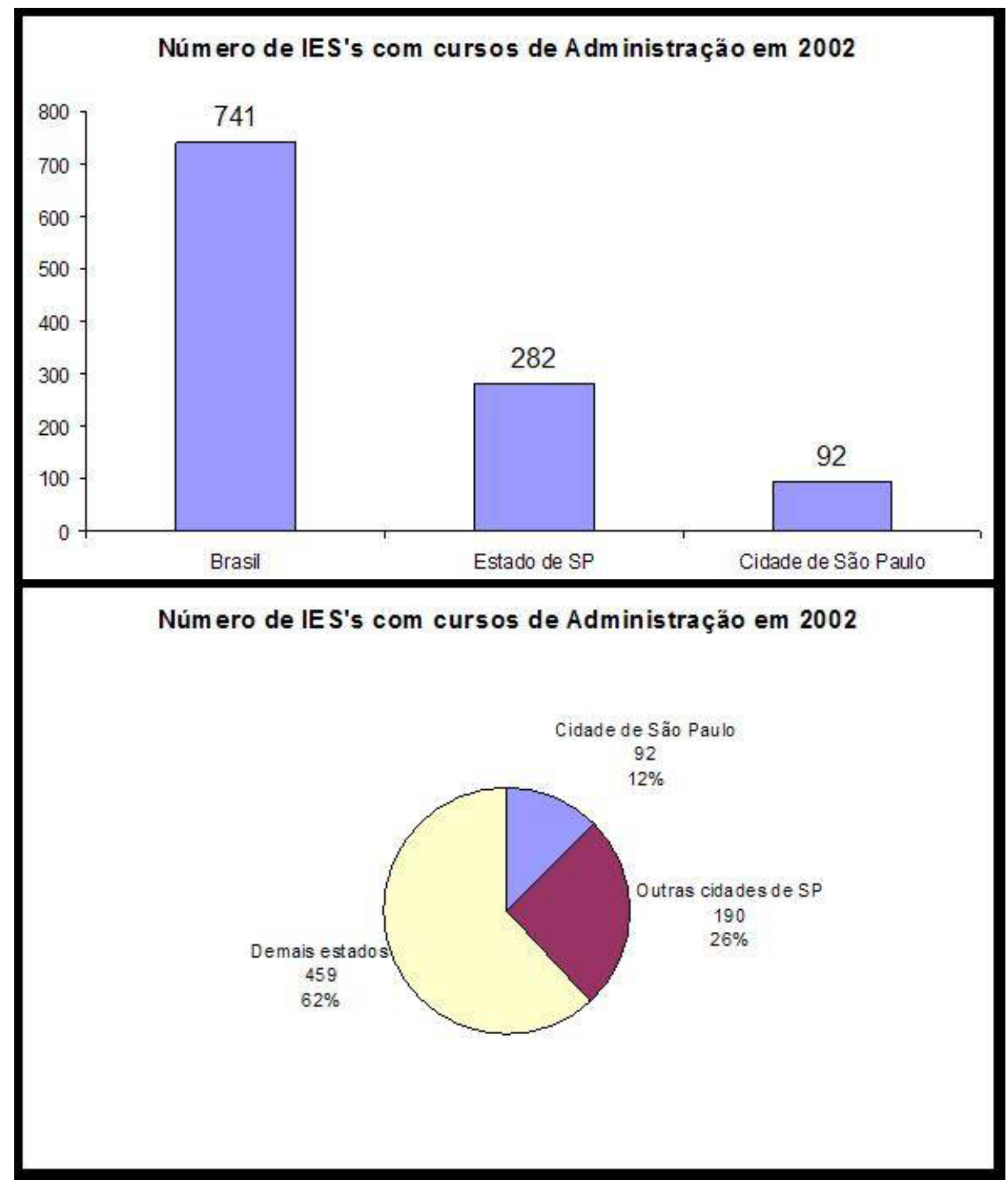

Figura 1: Distribuição das IES's com cursos de Administração em $2002^{5}$

Estes dados foram obtidos a partir das listagens disponíveis no site do Conselho Regional de Administração (CRASP on line, 2003a), mas a mensagem "Obs: Esta página está sendo atualizada. Por este motivo, as informações não estão completas. Gratos pela atenção." deixa claro que os números não são confiáveis, mas a idéia neste momento é apenas dar uma visão geral. Pelos dados da tabela 1 podemos estimar um total de 1100 cursos de Administração no Brasil em 2002. 
A justificativa para se fazer tal pesquisa pode ser dada pela demanda por atualização dos conteúdos e métodos de ensino, pelas dúvidas quanto à profundidade $\mathrm{e}$ abrangência dos tópicos de APO num curso de Administração, pela escassez de pesquisa ou pela quantidade e concentração de cursos de Administração na cidade de São Paulo, além disso, os resultados desta pesquisa podem trazer algumas contribuições, como:

- O conhecimento de quais os conteúdos e técnicas que têm sido utilizadas por algumas das principais escolas de Administração pode orientar outras Instituições de Ensino Superior (IES) nos seus planejamentos e decisões de modo a atingir novos patamares de qualidade no ensino de APO. ${ }^{6}$

- Os leitores desta pesquisa poderão observar analogias entre as características do ensino de APO e de outras disciplinas profissionalizantes, adaptando os resultados encontrados para a sua realidade ou área de interesse.

- Outra possibilidade está no uso dos resultados desta pesquisa como insumo para as atividades de revisão dos livros didáticos da área de APO e até na preparação de novos materiais para apoio ao ensino de APO como: filmes, softwares, casos, etc.

\footnotetext{
6 Não queremos dizer que os resultados sejam prontamente generalizáveis ou aplicáveis a qualquer IES, mas que estes resultados podem fomentá-las a avaliar suas práticas atuais e apontar algumas sugestões.
} 
CAPÍTULO 2

O estado-da-arte das pesquisas sobre o ensino de APO nos cursos de Administração de Empresas 


\title{
2 O estado-da-arte das pesquisas sobre o ensino de APO nos cursos de
}

\section{Administração de Empresas}

\author{
A Administração da Produção e Operações (APO) é uma área já consagrada no
} currículo do curso de Administração de Empresas e algumas definições podem ilustrar como ela tem sido delimitada:

A APO diz respeito àquelas atividades orientadas para a produção de um bem físico ou à prestação de um serviço. Neste sentido, a palavra "produção" liga-se mais de perto às atividades industriais, enquanto que a palavra "operações" refere-se às atividades desenvolvidas em empresas de serviços. [...] A APO é o campo de estudo dos conceitos e técnicas aplicáveis à tomada de decisões na função de Produção (empresas industriais) ou Operações (empresas de serviços) (MOREIRA, 2000, p. 1 3).

A Administração da Produção está na essência da vida empresarial, uma vez que representa o ato de criação. Está preocupada com a criação de produtos e serviços de que todos nós dependemos (SLACK et al., 1997, p. 21).

A função produção, entendida como o conjunto de atividades que levam à transformação de um bem tangível em um outro bem com maior utilidade [...]. Operações compõem o conjunto de todas as atividades da empresa relacionadas com a produção de bens e/ou serviços. [...] Como tais atividades, na tentativa de transformar insumos, tais como matérias-primas, em produtos acabados e/ou serviços, consomem recursos e nem sempre agregam valor ao produto final, constituí objetivo da APO a gestão eficaz dessas atividades (MARTINS; LAUGENI, 1998, p. 1 -5).

A partir de uma perspectiva corporativa, a administração da produção pode ser definida como o gerenciamento dos recursos diretos que são necessários para a obtenção dos produtos e serviços de uma organização. [...] A partir de uma perspectiva operacional, a administração da produção pode ser vista como um conjunto de componentes, cuja função está concentrada na conversão de um número de insumos em algum resultado desejado (DAVIS, AQUILANO; CHASE, 2001, p. 24 - 25).

"Gerenciar recursos e um conjunto de atividades" parece um tanto genérico para definir a "área" de APO, mas para o "ensino" de APO é possível melhorar esta definição citando algumas disciplinas que geralmente compõem esta área: Administração da Produção, Administração das Operações, Administração de Materiais, Organização da Produção, Organização Industrial, Tempos e Métodos, Logística, Administração da Qualidade e Produtividade. 
Para identificar o estado-da-arte da pesquisa sobre o ensino de APO nos cursos de graduação em Administração de Empresas, foi executada uma extensa busca por artigos e teses, seguida de uma análise de conteúdo para destacar os trabalhos mais relevantes para a presente pesquisa.

O resultado final dessa análise foi condensado na figura 2, a partir da qual é possível tecer os seguintes comentários:

- Dos tópicos relacionados ao ensino de APO, os mais pesquisados foram:

○ Conteúdo

- Método de ensino

○ Objetivos e estrutura do curso
(96,7\% - 29 trabalhos em 30)

$(63,3 \%$ - 19 trabalhos em 30)

(50,0\% - 15 trabalhos em 30)

- Comparando as pesquisas feitas na última década (15 trabalhos de 1994 a 2003) com aquelas mais antigas (15 trabalhos de 1978 a 1992) percebe-se o aumento do interesse por determinados tópicos:

- As dificuldades, desafios e tendências no ensino de APO foram citadas em oito trabalhos na última década contra apenas um trabalho mais antigo.

○ O sistema de avaliação foi citado em quatro trabalhos na última década contra apenas um trabalho mais antigo.

- Laboratórios e softwares foram citados em nove trabalhos da última década contra três trabalhos mais antigos.

- O corpo docente foi citado em onze trabalhos da última década contra quatro trabalhos mais antigos.

- O método de ensino foi citado em treze dos quinze trabalhos da última década contra seis trabalhos mais antigos. 


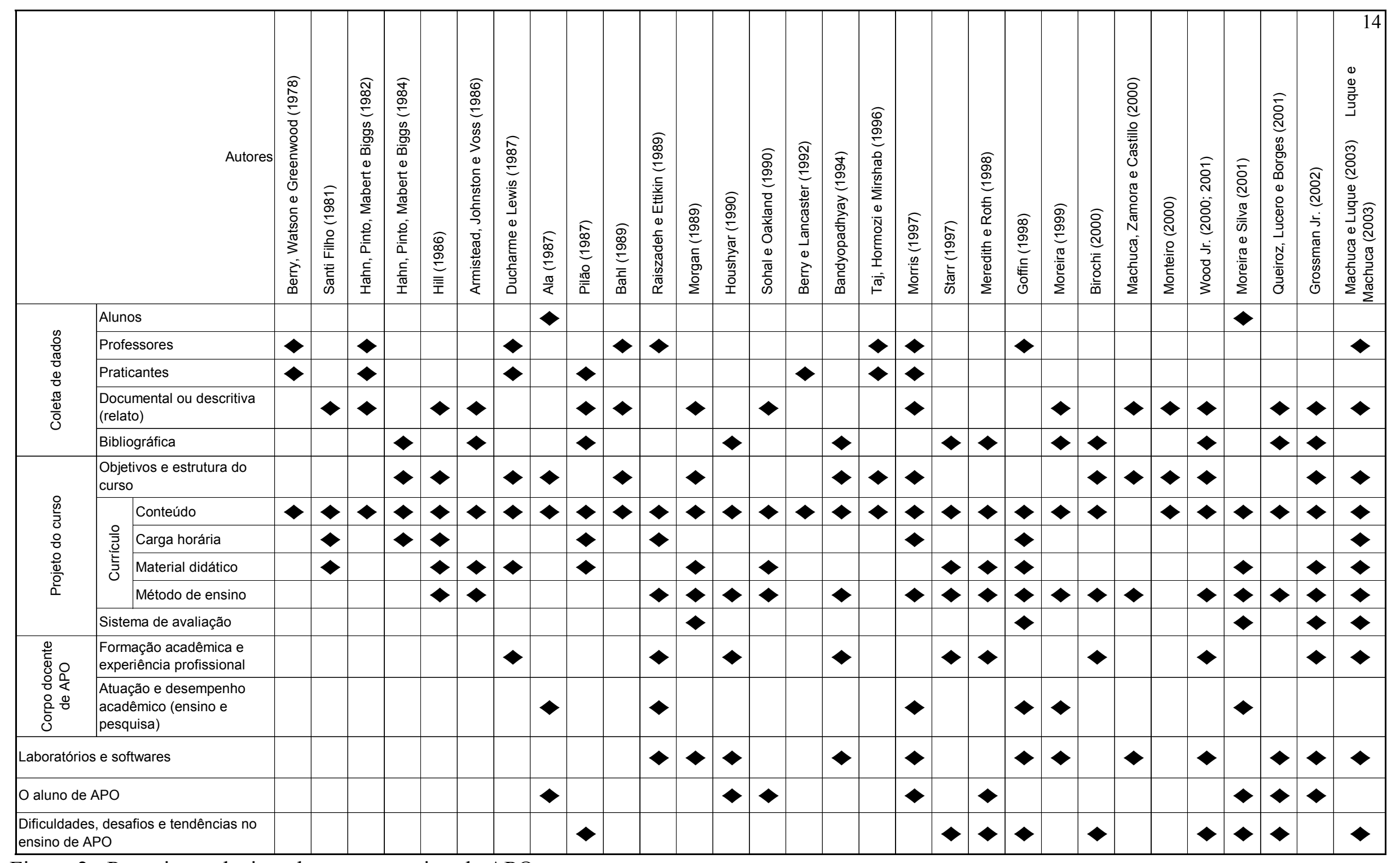

Figura 2: Pesquisas relacionadas com o ensino de APO 
A primeira coluna da figura 2 foi preparada de acordo com a estrutura das próximas seções deste capítulo, a saber: projeto do curso de APO, corpo docente de APO, laboratórios e softwares, o aluno de APO, dificuldades, desafios e tendências no ensino de APO, que são detalhados e comentados a seguir.

\subsection{Projeto do curso de APO}

Não se pretende entrar em detalhes sobre a elaboração do projeto pedagógico de um curso de Administração, mas é preciso destacar que cada curso deveria ser planejado de acordo com a realidade em que está inserido, como é recomendado a seguir:

Cada curso deve verificar o que é mais relevante, a partir de sua realidade interna e externa, para então definir o ementário e as bibliografias mais pertinentes que poderão ser utilizadas para a consolidação da missão, dos objetivos e do perfil profissiográfico pretendidos pelo curso (BRASIL on line, 1997?, p. 3).

Esse planejamento é dinâmico e, no Parecer 0134/2003 do Conselho Nacional de Educação, a necessidade de atualização é explicitada da seguinte forma:

\footnotetext{
As Diretrizes Curriculares Nacionais para o Curso de Graduação em Administração devem refletir uma dinâmica que atendam aos diferentes perfis de desempenho a cada momento exigidos pela sociedade, nessa "heterogeneidade das mudanças sociais" sempre acompanhadas de novas e mais sofisticadas tecnologias, a exigir contínuas revisões do Projeto Pedagógico de um curso para que ele se constitua a caixa de ressonância dessas efetivas demandas[...]. (BRASIL on line, 2003b).
}

Quanto ao perfil profissiográfico, há uma recomendação para que o administrador seja "Generalista-humanista que decide ética e responsavelmente empreendendo transformações com competência técnico-cientifica." (ANGRAD on line, 1996) e para a elaboração ou atualização desse perfil, Amatucci (2000) desenvolveu um método, que apresenta as seguintes vantagens:

- Existência de um ciclo de atualização do perfil, evitando a sua obsolescência;

- A "memória de cálculo" é usada como base para a futura atualização;

- O prazo de validade do perfil é definido;

- As variáveis (ou fatores) determinantes são explicitadas, o que permite detectar mudanças no ambiente que exija a atualização do perfil.

Finalmente, o currículo, além de garantir que os alunos tenham conhecimento técnico e profissional, também deveria ter o objetivo de atrair e reter os melhores alunos 
(DEINES, 2002, p. 69). Para atender esses objetivos, algumas questões devem ser respondidas no planejamento do curso:

- Quantas e quais as disciplinas?

- Qual a duração de cada uma?

- Qual a carga horária?

- Qual o conteúdo de cada disciplina (ementa e bibliografia)?

- Qual a série em que será ministrada cada disciplina?

- Qual a seqüência e inter-relação entre as disciplinas?

- Qual a metodologia de ensino para cada disciplina?

- Qual o sistema de avaliação?

O projeto do curso de APO (conjunto de disciplinas de APO) está subordinado ao projeto do curso de Administração e para a presente pesquisa foi considerado sob seis aspectos: objetivos e estrutura, conteúdo, carga horária, material didático, método de ensino e sistema de avaliação.

\subsubsection{Objetivos e estrutura do curso de APO}

Um dos desafios na definição dos múltiplos objetivos dos cursos de APO é que eles deveriam considerar as informações obtidas da universidade, das agências de credenciamento (accreditation), dos praticantes e dos professores. Além disso, estes objetivos também deveriam atingir um equilíbrio entre aspectos técnicos e estratégicos da APO, com aplicações em diversos campos, esclarecendo as relações entre APO e as outras áreas funcionais (MORGAN, 1989, p. 48).

O número de disciplinas obrigatórias e optativas, a carga horária e o semestre em que cada disciplina é ministrada definem a estrutura do curso de APO dentro do curso de graduação. Machuca e Luque (2003) tentaram fazer um censo dos cursos de APO na Espanha e obtiveram uma taxa de resposta de 70,5\% de um total de 241 professores ligados a 46 universidades. Dos resultados apresentados destacamos que:

- Foram considerados quatro cursos: licenciatura em Administração (4 ou 5 anos), “diplomatura” em Administração (3 anos), Engenharia Industrial (5 ou 6 anos) e técnico em Engenharia Industrial (3 anos).

- $70 \%$ dos cursos de APO são obrigatórios e 30\% são opcionais. 
- $64,4 \%$ dos cursos oferecem apenas uma disciplina de APO e 27,9\% oferecem apenas duas disciplinas, o restante oferece três ou mais disciplinas. Com tão poucas horas não é possível desenvolver a disciplina em profundidade, nem discutir aspectos estratégicos.

- $68 \%$ dos cursos têm duração de 45 a 60 horas, sendo a média geral de 61,1 horas.

- O número de alunos envolvidos em disciplinas de APO nos cursos de Administração é praticamente o dobro do número de alunos em cursos de Engenharia Industrial.

- A relação de alunos por professor no curso de Licenciatura em Administração é 125, enquanto para a Engenharia Industrial é de 62 alunos por professor.

- As disciplinas de APO se concentram principalmente nos últimos anos dos cursos, para a Licenciatura em Administração e engenharia industrial no ante-penúltimo e penúltimo ano de curso.

O período letivo das disciplinas de APO no curso de Administração é importante porque determina se alguns pré-requisitos foram atendidos ou não. Os exemplos a seguir reforçam a necessidade de pré-requisitos para algumas disciplinas:

a) Em 2001 o próprio autor lecionou a disciplina "Gestão da Qualidade e da Produtividade" para uma turma de $5^{\circ}$ ano de graduação em Administração de Empresas, sendo muito elogiado pelo uso de casos nacionais. No mesmo ano, em outra IES, ele lecionou a mesma disciplina para uma turma de $1^{\circ}$ ano de graduação em Administração de Empresas, obtendo um resultado desastroso, já que houve muita reclamação sobre os mesmos pontos que tinham sido elogiados na primeira IES.

b) Em 2002 um amigo do autor passou pelo mesmo problema. Ele obteve ótimos resultados quando lecionou "Economia" para uma turma de $3^{\circ}$ ano de Engenharia, mas houve grande desinteresse dos alunos quando lecionou a mesma disciplina para uma turma de $1^{\circ}$ ano de Engenharia em outra IES. 
Coerente com essa experiência pessoal e com os resultados de Machuca e Luque (2003), pode-se citar Morgan (1989, p. 48), que apresentou uma abordagem com resultados positivos nos cursos de graduação, e que tinha como pré-requisito a necessidade de que todos os alunos do curso introdutório de APO tivessem passado por cursos em métodos quantitativos, estatística e áreas funcionais, como: Marketing, Administração, Contabilidade e Finanças.

$\mathrm{Na}$ pesquisa sobre o ensino de APO nos cursos de Administração é preciso levar em conta que este tem sido preparado segundo diversas habilitações, ênfases, ou especialidades, como é usado no site do Conselho Regional de Administração:

Administração Esportiva, Agronegócios, Análise de Sistemas, Comércio Exterior, Comércio Internacional, Cultural, Empreendedorismo, Empreendedorismo e Negócios, Eventos, Financeira, Geral, Gestão ambiental, Gestão da informação, Gestão de Cidades, Gestão de Marketing, Gestão de Mercados, Gestão de Negócios, Gestão de Negócios Agroindustriais, Gestão de Negócios Internacionais, Gestão de Negócios na Internet, Gestão de Pequena e Média Empresa, Gestão de Produção Cultural, Gestão de Produção e Serviços, Gestão de Recursos Humanos, Gestão de Serviços, Gestão de Serviços Turísticos, Gestão de Sistemas de Informação, Gestão em Serviços de Saúde, Gestão Estratégica de Empresas, Gestão Hoteleira, Hospitalar, Hotelaria, Informação, Informática, Logística, Marketing, Meio Ambiente, Mercadológica, Negócios Internacionais, Produção Industrial, Pública, Recursos Humanos, Rural, Serviços, Serviços de Turismo, Sistema de Informação Gerencial, Sistemas da informação, Sistemas de Informação e Finanças, Transportes e Logística, Turismo (CRASP on line, 2003b).

A questão sobre a quantidade de APO (conteúdo e carga horária) que deveria ser incluída no curso de Administração em função da sua especialidade é interessante, mas não faz parte dos objetivos desta pesquisa. 


\subsubsection{Conteúdo}

Uma influência, externa à IES, na definição dos conteúdos programáticos são as Diretrizes Curriculares do curso de Administração (BRASIL on line, 2002; 2003a; 2003b), mas elas são insuficientes para a definição do que se deveria ensinar na APO, como se pode verificar no APÊNDICE A, que teve grifados os parágrafos que podem ser relacionados de alguma forma à $\mathrm{APO}$.

Abaixo das Diretrizes Curriculares temos o projeto pedagógico do curso com o perfil do egresso, que em parte define o conteúdo a ser ministrado. Em parte porque o conteúdo também depende da bibliografia disponibilizada pelas editoras, da influência do professor, que pode variar muito, dependendo de sua experiência profissional e acadêmica e da carga horária disponível para cada tópico.

Outro fator que deveria influenciar a definição dos conteúdos é a opinião dos praticantes, seja através de uma pesquisa direta ou através das informações obtidas em entidades profissionais, como Ducharme e Lewis (1987) utilizaram os conteúdos dos exames da APICS (The Educational Society for Resource Management) para avaliar a adequação do conteúdo dos tópicos de APO, ministrados nos cursos de graduação.

À guisa de exemplo pode-se citar algumas pesquisas, como a de 1978, em que houve forte concordância entre a opinião dos professores quanto ao curso ideal e o conteúdo que se lecionava, mas que divergia das opiniões dos gerentes. Os professores davam maior ênfase às técnicas analíticas enquanto os gerentes tendiam mais para os conceitos de produção (BERRY; WATSON; GREENWOOD). Na pesquisa de 1992 os gerentes concordaram em que aproximadamente um terço do curso deveria ser dedicado às técnicas quantitativas e o restante para os conceitos de produção (BERRY; LANCASTER).

Taj, Hormozi e Mirshab (1996) solicitaram que os executivos ordenassem (rank), de acordo com a importância, as 16 disciplinas oferecidas nos programas de Administração de Operações e Administração Industrial. As cinco disciplinas mais citadas foram: Estratégias de Operações, Análise e Pesquisa; Planejamento e Controle de Operações; Administração e Controle da Qualidade; Planejamento e Projeto do Produto para Manufatura e Administração da Tecnologia de Manufatura. 
Em 1986 Armistead, Johnston e Voss já apontavam a necessidade de se incluir textos sobre as operações em serviços, e Hill (1986) afirmava que era essencial ensinar APO (visto como atividades operacionais), mas que a orientação do curso e os materiais utilizados também deveriam incluir assuntos estratégicos. Em 1989, Bahl voltou a fazer essas recomendações.

Hahn, Pinto, Mabert e Biggs (1982) classificaram as disciplinas oferecidas em quatro categorias: disciplinas que representariam o núcleo (core) de APO, disciplinas ligadas a área de materiais, ferramentas quantitativas e disciplinas comportamentais. Nessa época, os principais tópicos nos cursos introdutórios de APO eram: Programação da produção e controle do chão de fábrica, Modelos de estoque, Previsão, Planejamento agregado e plano mestre, Layout, Projeto da estação de trabalho, Políticas gerais e sistemas para a administração de estoques, Modelos estatísticos para o controle da qualidade, MRP e Localização.

Hahn, Pinto, Mabert e Biggs (1984) apresentaram algumas orientações para a estruturação do currículo das disciplinas de APO:

- Orientação conceitual versus Orientação técnica.

- Orientação para a manufatura ou serviço.

- Enfoque funcional ou político.

- Nível inicial de habilidades versus Nível mais alto de habilidades gerenciais.

- Relação com outras áreas funcionais.

Raiszadeh e Ettikin (1989) levantaram a ênfase que estava sendo dada e a que se pretendia dar após três anos nos tópicos de APO: CEP, Previsão, EOQ / POQ, MRP / MRP II, Estratégia de manufatura, JIT / ZI, Oportunidades de carreira, FMS, Círculos da Qualidade e setor de serviços. Os resultados sugeriam que os acadêmicos estavam tentando responder às mudanças na $\mathrm{APO}$, dando maior ênfase em vários tópicos nos próximos anos. 
Na pesquisa de 1989, Berry e Lancaster (1992) avaliaram os materiais de APO e perceberam que alguns tópicos não estavam tendo a ênfase que tinham tido uma década antes e que logicamente estes tópicos deveriam estar sendo tratados em cursos de suas áreas funcionais como Finanças e Contabilidade.

Bandyopadhyay (1994) elaborou uma proposta para o programa do curso de APO, visando atender as necessidades dos gerentes, como habilidade técnica, analítica, conceitual e interpessoal, mas também atendendo os requisitos da AACSB. O programa proposto constava de três módulos:

- Módulo 1: É composto pelas disciplinas de Administração

- Módulo 2: É o módulo básico de APO

- Módulo 3: É o módulo de especialização

Morris (1997) apresenta os esforços que têm sido feitos para reprojetar o currículo básico do curso de Administração da Universidade de Idaho, de modo que haja maior integração entre as disciplinas básicas (Business Common Core Courses), que têm duração de um ano. No currículo novo, a disciplina de APO foi integrada às outras áreas, sendo criados seis módulos. No primeiro semestre foram desenvolvidos quatro módulos com a finalidade de dar uma visão geral da empresa com planejamento de longo prazo e no segundo semestre os outros dois módulos focavam mais nas operações cotidianas da empresa. Os módulos são: Sistemas de Negócios; Gerência de Equipes; Planejamento e tomada de decisões nas organizações; Planejamento do produto e do processo; Gerência dos recursos da empresa e Decisões operacionais de negócios.

Mesmo no MBA, há muita controvérsia quanto ao foco do curso (manufatura versus serviço e estratégia versus tática), alguns professores reconhecem a importância de enfatizar a estratégia, mas afirmam que seria perigoso abandonar as ferramentas e técnicas. A dificuldade para equilibrar a ênfase em manufatura ou serviço também é reconhecida e uma das justificativas apresentadas para continuar com uma ênfase maior em manufatura é que os casos aplicados em serviço não ilustram tão efetivamente os conceitos de operações (GOFFIN, 1998).

Monteiro (on line, 2000) analisou o currículo do período diurno vigente nos anos de 1980, 1990 e 2000 do curso de graduação em Administração de Empresas da FEA-USP e 
concluiu que as mudanças na estrutura curricular das disciplinas da área de APO tem mantido o currículo adequado às necessidades de profissionalização.

Nas IES's da Espanha foi observado que 54,0\% dos cursos têm foco táticooperacional, sendo as disciplinas de APO concentradas nos últimos anos dos cursos. Nessa mesma pesquisa Machuca e Luque (2003) identificaram 28 tópicos nos programas de APO e aqueles que apareceram em pelo menos $50 \%$ dos programas foram considerados como o núcleo básico de APO: JIT, Qualidade, Estratégias de operações, MRP/ERP, Capacidade, Gestão de processo, Plano mestre e agregado, Localização, Projeto do produto, Sistemas de estoque para demanda independente, Problemas-chave de APO, Layout, Administração de projetos, Programação, História da APO, Previsão de demanda, Projeto e medida do trabalho e Teoria das restrições.

Pelos trabalhos comentados, podemos concluir que o conteúdo de APO tem sido extensivamente pesquisado, apesar da escassez de pesquisas brasileiras. Esse interesse pelo conteúdo aparece de diversas formas, ora relacionando o que se ensina com o que se demanda na prática, ora se classificando os conteúdos (núcleo de APO, que deveria ser ensinado prioritariamente) e outras vezes descrevendo as tentativas para se integrar os conteúdos de APO aos de outras áreas da administração.

\subsubsection{Carga horária}

A carga horária é um fator que por si só restringe o conteúdo e a profundidade com que a APO pode ser tratada no curso de Administração (HILL, 1986), como ocorre com qualquer disciplina. Por este motivo algumas pesquisas chegam a propor conteúdos ou estruturas para as disciplinas de APO, mas não definem a carga horária como é o caso de Hahn, Pinto, Mabert e Biggs (1984). Por outro lado, Raiszadeh e Ettikin (1989) descrevem a carga horária por tópico de APO, enquanto Morris (1997) relata uma duração de 15 a 60 horas para cada um dos seis módulos do curso de Administração da Universidade de Idaho, que foram comentados na seção anterior.

De maior interesse para a presente pesquisa foi o resultado obtido por Santi Filho (1981, p. 63), que através da análise de 16 programas de IES's do município de São Paulo chegou às seguintes cargas horárias: 
- Administração da Produção: carga horária variando de 32 a 288 horas-aula, com uma média de 103 horas-aula, representando 3,6\% da carga horária total do curso.

- Administração de Materiais: carga horária variando de 32 a 140 horas-aula, com uma média de 73 horas-aula, representando $2,5 \%$ da carga horária total do curso.

Em 1987 Pilão (p. 67-79) executou uma pesquisa similar à de Santi Filho, mas focando especificamente nas disciplinas da área de APO e outras afins ou complementares, obtendo os seguintes resultados para os 34 programas analisados:

- Administração da produção: carga horária variando de 32 a 192 horas-aula, com uma média de 98 horas-aula, representando 3,63\% da carga horária total do curso.

- Administração de materiais: carga horária variando de 32 a 192 horas-aula, com uma média de 88 horas-aula, representando $3,26 \%$ da carga horária total do curso.

Para as IES’s espanholas, Machuca e Luque (2003) verificaram que 68\% dos cursos têm duração de 45 a 60 horas (média de 61,1 horas), sendo que 64,4\% dos cursos oferecem apenas uma disciplina de APO e 27,9\% oferecem apenas duas disciplinas.

\subsubsection{Material didático}

É principalmente pelo material didático que será determinada a atualidade dos tópicos abordados no curso, ressaltando que os artigos publicados em revistas trazem os materiais mais recentes, enquanto os livros sobre tópicos mais específicos tratam de um conteúdo e histórico mais amplos que os artigos, enquanto os livros didáticos (ou livrostexto) podem abranger várias décadas e incluir os tópicos mais atuais em capítulos adicionais. É importante lembrar que o conteúdo não deveria ser apenas atual, mas deveria preparar o aluno para o futuro (quando se formar).

As pesquisas de Santi Filho (1981) e Pilão (1987) foram pioneiras em detalhar o material que estava sendo usado nas disciplinas de APO nas escolas paulistas. A seguir destacam-se alguns de seus resultados.

Em 1981 os livros-texto tinham sido editados de 4 a 23 anos antes e dos 16 programas analisados por Santi Filho os títulos mais citados foram:

- Para a disciplina de Administração da Produção: 
○ Com 11 indicações: MACHLINE, Claude; MOTTA, Ivan S.; SCHOEPS, Wolfgang e WEIL, Kurt E. Manual da administração da produção - vol. I e II. Rio de Janeiro: Fundação Getúlio Vargas, 1970.

- Com 7 indicações: ZACARELLI, Sérgio B. Programação e controle da produção. São Paulo, CEPAI - Pioneira, 1967.

- Com 7 indicações: BUFFA, Elwood S. Administração da produção. Rio de Janeiro: LTC, 1972.

- Para a disciplina Administração de materiais:

- Com 6 indicações: MAGEE, John F. Planejamento e controle da produção. São Paulo: Pioneira, 1958.

Pilão comenta que em 1987 havia uma variedade muito grande de livros adotados pelas 34 IES's, sendo aproximadamente 50 títulos para a disciplina Administração da produção e 40 para a disciplina Administração de materiais, entretanto mais da metade dessas obras eram encontradas com apenas uma indicação e que ainda era complementada por apostilas elaboradas pelos próprios professores. Os livros mais indicados eram:

- Para a disciplina de Administração da Produção:

- Com 22 indicações: MACHLINE, Claude; MOTTA, Ivan S.; SCHOEPS, Wolfgang e WEIL, Kurt E. Manual da administração da produção - vol. I e II. Rio de Janeiro: Fundação Getúlio Vargas, 19??.

○ Com 17 indicações: BUFFA, Elwood S. Administração da produção. Vol. I e II. Rio de Janeiro: LTC, 19??.

- Para a disciplina Administração de materiais:

- Com 22 indicações: AMMER, Deans. Administração de materiais. Rio de Janeiro: LTC, 19??.

○ Com 19 indicações: ARAÚJO, Jorge S. Administração de materiais. São Paulo: Atlas, 19??.

- Com 19 indicações: ZACARELLI, Sérgio B. Programação e controle da produção. São Paulo, Pioneira, 19??.

Em 1987, a maioria dos livros-texto americanos já possuíam capítulos sobre MRP, JIT e planejamento da capacidade (DUCHARME; LEWIS, 1987). 
Da bibliografia utilizada nos cursos de MBA, Goffin (1998) destacou que quatro escolas utilizavam SLACK, N. et al. (1995). Operations Management, Pitman, London. Enquanto outras quatro escolas utilizam GOLDRATT, E. M.; COX, J. (1986). The Goal, North River Press.

$\mathrm{Na}$ Espanha a maioria dos livros-texto disponíveis é de origem americana e, apesar de haver trinta títulos em uso nos cursos de APO, os dois livros mais usados são de autoria de professores espanhóis mesmo (LUQUE; MACHUCA, 2003).

Dada a importância dos livros didáticos para o ensino de APO e a ausência de pesquisas sobre os livros disponíveis atualmente no Brasil, sentimo-nos motivados a elaborar uma análise, que é apresentada no capítulo 4.

\subsubsection{Método de ensino}

Já em 1985, Teixeira indicava que para o aperfeiçoamento da educação formal universitária, e em especial o ensino de Administração, era necessária uma mudança de abordagem, isto é, transferir para o aluno a responsabilidade do processo de aprendizagem, que tradicionalmente é atribuída ao professor, através de técnicas não-diretivas e métodos vivenciais .

Neste sentido, Sohal e Oakland (1990) apresentam quatro estudos de caso que podem ser usados no ensino de APO. Os alunos experimentam tarefas de um gerente de produção/operações e buscam um entendimento sobre a complexidade das questões envolvidas, por exemplo, em layout, CEP e outras. A busca por uma maior participação dos alunos também foi comentada por Houshyar (1990, p.30): 
Eu tenho sentido muita dificuldade para manter o interesse dos alunos em questões puramente quantitativas, enquanto discutir as questões qualitativamente e usar software para complementar o curso tem resultado em um grande impacto na capacidade dos alunos em absorver a matéria e os problemas de APO relacionados ao mundo real ${ }^{7}$.

Profeta (2000) comenta as várias técnicas que ele tem utilizado, com resultados positivos (aumento de $10 \%$ nas aprovações e $25 \%$ no conteúdo programático) no ensino de Administração da Produção, por exemplo:

- Apresentação do Programa: Através da apresentação de um vídeo ("Pink Floyd”, "Disney" ou “Titanic") na primeira aula, são apresentados os detalhes do planejamento, organização, controle e da direção, focalizando a importância de uma equipe que tenha sob sua responsabilidade a condução do negócio como um todo.

- Estruturação das aulas: Apresentação de conceitos, apresentação de exemplos, exercício de fixação (exemplo flexibilizado), fixação do conceito, fixação da aplicação da técnica (exercício inventado), exercícios resolvidos - comentar processo de solução, revisão crítica da técnica, exercícios monitorados (listas), comentários sobre processos de solução.

- Metodologia didática: Workshop, seminários, estudos de casos, aula expositiva.

- Recursos Instrucionais: Lousa, retroprojetor, multimídia, "teatralização"

- Sistema de Avaliação: Trabalho em equipes, exercícios monitorados, trabalho em pesquisas, participação e freqüência às aulas, provas individuais.

A importância de se ter projetos como empresa júnior, consultoria ou estágio, que envolvam os alunos, professores e a própria escola com o "mundo real", mereceu um destaque especial na revista Interfaces, que publicou na sua edição de Março-Abril de 2002 uma seção com quatro artigos dedicados a este tema. Alguns benefícios para a escola são: feedback claro sobre as capacidades reais dos alunos, ampla conexão com a indústria local, materiais para estudos de caso e pesquisa e até a possibilidade de se melhorarem os cursos que têm sido oferecidos (GROSSMAN JR., 2002).

\footnotetext{
7 Versão original: "I have found it very difficult to maintain students' interest in the purely quantitative issues, whereas discussing the matters quanlitatively and using software to supplement the course has had great impact on students' ability to absorb the subject and relate it to the real world P/OM problems."
} 
Em relação aos estágios, Rodrigues (2002) comenta que, no Brasil, o Centro de Integração Empresa-Escola (CIEE) tem desenvolvido parcerias com empresas como Volkswagen. A Alstom, por outro lado, tem feito um trabalho interno de escolha de universidades específicas e algumas escolas, como a FGV-EAESP e a Faculdade Trevisan, que possuem departamentos próprios para a colocação do estudante no mercado.

Raiszadeh e Ettikin (1989) encontraram para cada metodologia de ensino as seguintes ênfases no uso: Aulas expositivas (97,2\% pesada ou moderada), Casos (32,9\% pesada ou moderada), Microcomputador (42,4\% pesada ou moderada), Mainframe (16,2\% alguma ênfase), Visitas às empresas (9,6\% pesada ou moderada), Filmes e vídeos (10,1\% pesada ou moderada) e Palestra com praticantes (10,3\% pesada ou moderada).

As recomendações feitas por Bandyopadhyay (1994) incluem: maior ênfase na análise de casos, com a apresentação de filmes e vídeos; viagens ao campo e palestra com gerentes; uso de computadores e programas de aplicação, de MRP, de simulação e de jogos estratégicos de manufatura; casos integrativos no curso de Estratégias de manufatura; não trabalhar apenas com problemas pequenos e isolados, encorajar os alunos para os problemas reais de previsão, planejamento e MRP; finalmente, a universidade deveria desenvolver programas de cooperação com as empresas, por exemplo, através de estágios para os alunos.

Para se obter uma integração entre as disciplinas básicas, Morris (1997) aponta o uso de casos integrativos, com os alunos trabalhando em grupo e sendo auxiliados pelos professores e também a ligação com outras corporações através de palestras com executivos que apresentam exemplos de suas companhias.

As aulas expositivas têm sido predominantes no Brasil, mas deveriam ser privilegiadas as técnicas mais dinâmicas como: estudos de caso, simulações, uso de computador, uso de filmes e vídeos, visitas às fábricas ou outras organizações e palestras de praticantes, que dêem ao aluno a oportunidade de construir o seu conhecimento, dandolhe a chance de treinar habilidades como: capacidade de liderar, de trabalhar em grupo, de tomar decisões, de formar juízos e de atuar em situações ambientes relativamente ambíguos (MOREIRA, 1999). 
$\mathrm{Na}$ Espanha a aula expositiva também tem sido o método mais usado, o que foi justificado por Machuca e Luque (2003) pelas seguintes causas:

- grande número de alunos em sala de aula leva o professor a adotar a aula expositiva como único método possível;

- falta de recursos, principalmente multimídia e jogos de empresas;

- falta de software adequado, de um lado temos os softwares caros que são desenvolvidos por companhias e de outro os softwares mais simples, geralmente não amigáveis e

- grande expansão do conteúdo do curso com um número de aulas insuficiente, novamente tendendo ao uso de aulas expositivas.

Com o uso da simulação, como descrita por Machuca, Zamora e Castillo (2000), teríamos que repensar os cursos de APO e até o curso de Administração como um todo, porque o aprendizado dependeria muito mais da atividade do próprio aluno, podendo mesmo ser fora da aula e até à distância. Em apoio a este método de ensino, Queiroz, Lucero e Borges (on line, 2001) relatam que a implementação do Jogo da Produção foi recebida com tanto entusiasmo pelos alunos, que incentivou o grupo a expandir o sistema para outras tarefas além do planejamento e programação da produção de uma fábrica.

$\mathrm{Na}$ opinião dos alunos, a melhoria da qualidade das aulas de Administração da Produção passa por ações do professor como: incrementar o volume de exercícios, trazer exemplos práticos e intercalar exercícios com teoria, mas também por ações dos alunos como: maior empenho, dedicação e prestar atenção nas aulas (MOREIRA; SILVA on line, 2001). 


\subsubsection{Sistema de avaliação}

O sistema de avaliação a ser utilizado depende do conteúdo, mas principalmente do método de ensino. Sant'anna (2001) discute em detalhes os tipos e instrumentos de avaliação e aponta o uso da avaliação como uma forma de auxiliar na construção do conhecimento:

A avaliação só será eficiente e eficaz se ocorrer de forma interativa entre professor e aluno, ambos caminhando na mesma direção, em busca dos mesmos objetivos.

O aluno não será um sujeito passivo; e o professor, a autoridade que decide o que o aluno precisa saber. [...]

É preciso, para realizar uma avaliação coerente com os objetivos educacionais, levar em consideração a necessidade de uma ação cooperativa entre os participantes do processo [...]. (p. $27-28)$.

Os trabalhos comentados a seguir são coerentes com as recomendações de Sant'anna (2001), pois exemplificam o uso de mais de um método de avaliação, mantendo a adequação ao método de ensino utilizado.

Morgan (1989, p. 49) descreve um sistema de avaliação que é apropriado quando são utilizados estudos de caso como método de ensino. Os alunos submetem um sumário de seu trabalho na forma de memorando com a documentação da análise e da decisão ou recomendação dada. A avaliação leva em conta não só a precisão dos cálculos, mas também a qualidade da documentação apresentada (clara, concisa e completa).

Nos cursos de MBA da Europa têm sido usadas várias combinações de pelo menos dois métodos de avaliação: exames, avaliações de casos, projetos e participação em classe (GOFFIN, 1998). Em estudo mais recente, Luque e Machuca (2003) identificaram que nos cursos superiores da Espanha têm sido usados, simultaneamente, de dois a quatro métodos diferentes de avaliação: provas com exercícios e problemas a serem resolvidos, provas teóricas com questões a serem respondidas, projetos ou estudos desenvolvidos pelos alunos fora da aula, participação do aluno em sala de aula e provas do tipo múltipla escolha.

O Provão tem sido usado como recurso didático e modelo para avaliações em cursos de Administração e a pesquisa de Moreira e Silva (on line, 2001) é interessante justamente por evidenciar a reprovação dos alunos à mudança na sistemática de avaliação, que passou a utilizar várias questões discursivas, o que não era comum até aquele momento (método de avaliação inadequado ao método de ensino), ou seja, os exercícios de 
aula não tinham preparado os alunos para responderem questões discursivas ou articular vários conceitos de APO simultaneamente.

\subsection{O corpo docente de APO}

No Brasil o INEP (on line, 2002) tem avaliado as condições de ensino dos cursos de graduação e para o corpo docente têm sido consideradas três categorias:

- Formação acadêmica e profissional: Titulação, Experiência profissional, Adequação da formação;

- Condições de trabalho: Regime de trabalho, Plano de carreira, Estímulos (ou incentivos) profissionais, Dedicação ao curso, Relação alunos/docente, Relação disciplinas/docente;

- Atuação e desempenho acadêmico e profissional: Publicações, Produções intelectuais, técnicas, pedagógicas, artísticas e culturais, Atividades relacionadas ao ensino de graduação, Atuação nas atividades acadêmicas.

Essas categorias procuram avaliar o corpo docente como um todo, mas dentro da sala de aula o desempenho do professor está ligado a outras variáveis, que podem ser agrupadas em duas dimensões que se interagem:

A dimensão de relacionamento diz respeito à forma como o professor encara o ensino em geral, seus alunos e o relacionamento professor-aluno. Diz respeito à maior ou menor flexibilidade em enfrentar situações novas em sala de aula e à maior ou menor habilidade em resolver os problemas comportamentais corriqueiros na situação de ensino-aprendizagem.

A dimensão cognitiva envolve aspectos intelectuais e técnicodidáticos; diz respeito ao conhecimento e uso de técnicas de ensino, ao conhecimento do conteúdo e à maior ou menor capacidade de adaptar as técnicas ao conteúdo, tornando-o acessível aos alunos [...]. (MOREIRA, 1997, p. 71).

A pesquisa de Godoy, Silva, Anchieta e Mariz (on line, 2001) exemplifica essas dimensões. Eles identificaram seis fatores ligados às preferências dos alunos, nos quais é possível observar que o professor é o agente de maior influência, por exemplo, nas afirmações:

- Professores entusiasmados com seu trabalho docente

- Professores flexíveis que se adaptam às necessidades dos alunos

- Professores que dão exemplos relacionados com o dia-a-dia dos alunos 
Essas categorias, dimensões ou fatores são relevantes ao se estudar a atuação do corpo docente de qualquer área da Administração e para os professores de APO pode-se acrescentar mais algumas especificidades, que são comentadas a seguir.

Os professores de APO deveriam ser encorajados a um desenvolvimento profissional contínuo, buscando treinamento e certificações profissionais e não apenas fazendo pesquisas teóricas. O envolvimento com associações profissionais é essencial para a troca de idéias entre acadêmicos e práticos. Por outro lado, o suporte financeiro da universidade é importante para a aquisição dos recursos necessários e também para o recrutamento e manutenção de professores qualificados e experientes (BANDYOPADHYAY, 1994).

Em 1987, Ducharme e Lewis já tinham observado que muitos professores eram certificados pela APICS (CPIM) e no ano de 1989, Raiszadeh e Ettikin verificaram que a formação (grau e área) bem como a afiliação acadêmica ou profissional (AM, APICS, DSI, IIE, ORSA ou TIMS) dos professores têm influência nas metodologias de ensino: aulas expositivas, casos, microcomputador, mainframe, visitas às empresas, filmes e vídeos, palestra com praticantes.

Nas pesquisas de Morris (1997) e de Goffin (1998), ficou evidente a importância dos professores para se conseguir uma integração maior entre as disciplinas básicas, através do trabalho em equipe interfuncional, encontrando-se semanalmente para rever os exercícios e o material da semana seguinte, desenvolvendo material para projetos didáticos, discutindo as avaliações e usando mais casos.

A necessidade de professores de APO preparados para ensinarem questões sobre negócios internacionais é um dos desafios para a internacionalização do currículo de APO (STARR, 1997).

Uma recomendação para os professores, e em particular para os de APO, é que eles deveriam tornar-se pesquisadores dos impactos de seus próprios métodos de ensino, dos tópicos de compreensão mais fácil ou mais difícil, das particulares dificuldades dos alunos com técnicas analíticas, e assim por diante (MOREIRA, 1999). Além disso, eles também deveriam divulgar os benefícios de se estudar APO, mas, antes disso, o curso de APO 
deveria ser promovido aos administradores e professores. Com a ajuda de organizações como a APICS dentro da universidade e com palestras de gerentes de produção (ALA, 1987).

\subsection{Laboratórios e softwares}

Apesar da revisão da literatura sobre o ensino de APO ter sido bastante abrangente, ficou evidenciado que a maioria das pesquisas tem abordado o problema do conteúdo e das estratégias de ensino, pouco se falando sobre as instalações necessárias. Mesmo assim, pelo que foi dito a respeito das estratégias de ensino, pode-se inferir sobre os laboratórios, softwares e as instalações de um modo geral, por exemplo:

- Bandyopadhyay (1994) e Moreira (1999) recomendam o uso de filmes, vídeos, computadores, programas (aplicação, MRP, simulação). Para as palestras com gerentes também é pressuposto que a escola tenha um auditório com os recursos multimídia, a menos que se pense em palestras na própria sala de aula. Goffin (1998) também relata o uso intensivo de vídeos na própria sala de aula.

- Morris (1997) relata que os professores se encontravam semanalmente e que os alunos faziam trabalhos em grupo sendo auxiliados pelos professores. Resulta daí a necessidade da escola ter espaços adequados para este tipo de trabalho, incluindo recursos como computador e softwares.

- Praticamente todas as pesquisas citaram o uso de casos como uma forma de melhorar o entendimento dos conceitos de produção. Goffin (1998), por exemplo, chegou a comentar que uma das escolas pesquisadas preparava seus próprios vídeos. Então quais tipos de instalações as escolas deveriam ter para produzir casos e até filmes?

- Não basta um laboratório com a quantidade suficiente de computadores; o uso de simuladores depende da aquisição de softwares específicos ou do desenvolvimento interno, como foi descrito por Machuca, Zamora e Castillo (2000), Queiroz, Lucero e Borges (on line, 2001) e Houshyar (1990).

- Wood Jr $(2000 ; 2001)$ comentou duas inovações que hoje em dia têm sido de uso comum por qualquer professor, desde que os alunos tenham acesso aos computadores com Internet: é a utilização da Internet para acesso ao material de aula como transparências e apostilas e a utilização do correio eletrônico para avisos e divulgação de notícias relacionadas à disciplina. 


\section{$2.4 \mathrm{O}$ aluno de APO}

Até este momento foram apresentadas algumas variáveis envolvidas no ensino de APO que a IES tem certa autonomia para controlar, alterar ou atualizar, como: objetivos e estrutura do curso, conteúdo, sistema de avaliação e até mesmo o corpo docente. Entretanto, o tipo de aluno que a procura é mais ou menos determinado pelo contexto histórico e geográfico da instituição, por exemplo, uma escola que tem grande procura por seus cursos pode selecionar os melhores candidatos, o que reflete na própria qualidade do curso a ser dado. Por outro lado, uma escola já conhecida (contexto, "má fama", etc.) que decidisse atrair os melhores candidatos, dificilmente teria sucesso no curto prazo.

De modo geral, o aluno de APO é citado em várias pesquisas como uma forma de validar um método de ensino. Queiroz, Lucero e Borges (on line, 2001) mencionam que os alunos ficaram entusiasmados com o uso do Jogo da Produção e Grossman Jr. (2002) afirma que os alunos gostaram de participar em atividades ligadas à realidade (consultoria ou atividades de extensão). Por outro lado, algumas pesquisas comentam as opiniões e dificuldades que os alunos têm com o conteúdo de APO e alguns exemplos são dados nos próximos parágrafos.

Os alunos reconhecem a importância da disciplina de Administração da Produção para a sua formação profissional citando: a habilitação para a tomada de decisões operacionais, a aquisição de conhecimentos para a tomada de decisões operacionais e o conhecimento dos processos operacionais e técnicas específicas da área (MOREIRA; SILVA on line, 2001).

Numa pesquisa americana, os alunos indicaram, no início do curso, que a principal razão que os levou a participar do curso de APO é que ele era obrigatório, mas ao final do curso foram apontados vários benefícios: exposição à tecnologia, aprender habilidades para decisões pessoais, aprender a terminologia de APO, conquistar oportunidades na carreira, tornar-se um generalista, restabelecer o status internacional dos Estados Unidos, aumentar a cooperação dentro da Empresa, aprender habilidades para a tomada de decisões no âmbito da Administração Geral, aprender habilidades gerenciais (genéricas) (ALA, 1987). 
Morris (1997) comenta que a grande heterogeneidade no grupo de alunos dificulta o planejamento dos cursos e que a dificuldade que os alunos encontram com a matemática é uma das causas das deficiências em APO, que eles levam ao longo de suas carreiras. Meredith e Roth (1998) acrescentam que o uso continuado de métodos quantitativos ao longo de todo o curso de APO tende a reduzir a popularidade das aulas de APO junto aos alunos, que têm preferido cursos de consultoria, empreendedorismo, negócios internacionais e gestão de projetos, pelo menos para os alunos do sudeste dos EUA.

No mesmo sentido é a observação feita por Grossman (2002, p. 43 - 45) de que os alunos têm muita dificuldade na modelagem de problemas, bem como na aplicação de modelos, mas que a maioria deles recebe bem os projetos que lidam com problemas reais.

\subsection{Dificuldades, desafios e tendências no ensino de APO}

Como o ensino de qualquer disciplina profissionalizante é algo dinâmico, pode-se deduzir que a "escola" deveria constantemente investigar as tendências, desafios e até mesmo as dificuldades dos professores e alunos no ensino-aprendizagem de APO, como uma forma de aprimorar seus cursos. Nos parágrafos a seguir são apresentados alguns resultados das pesquisas analisadas. 
Goffin (1998) cita três desafios no ensino de APO:

- Dificuldade com o escopo da matéria em si (conteúdo, estrutura).

- Preocupações sobre como melhor demonstrar a importância e a relevância de APO.

- A dificuldade de ensinar uma matéria aplicada, que está em constante mudança.

Takei, Nascimento e Putvinskis (on line, 2001) comentam que as IES's têm feito mudanças e eliminações de disciplinas com incorporação a outras disciplinas. Através das avaliações das disciplinas têm-se verificado a sobreposição de disciplinas e a adequação às práticas do mercado, através de providências como: contratação de professores com experiência no mercado; apoio do conteúdo exigido no Exame Nacional de Cursos (Provão); conversas informais com professores que atuam no mercado; Verificando as necessidades do mercado através da imprensa ou avaliando os currículos de outras instituições (FGV, USP, etc.) entre outras.

Wood Jr. (2000; 2001) cita cinco desafios para o ensino de APO:

- Como dosar abrangência e profundidade, proporcionando aos alunos uma visão ao mesmo tempo ampla e consistente dos temas vistos?

- Como acompanhar adequadamente a velocidade de renovação dos assuntos?

- Como separar novas idéias e teorias de modas e modismos gerenciais?

- Como gerir interfaces com outras disciplinas?

- Sob o aspecto da didática, o maior desafio continua sendo aumentar o nível de participação dos estudantes, estimulando seu comprometimento como sujeito do processo de aprendizado.

Birochi (on line, 2000) destaca a iniciativa da Universidade Anhembi Morumbi com o objetivo de alcançar uma integração interdisciplinar entre as disciplinas do curso de Administração. Por outro lado, ele também enfatiza a necessidade de se fazer uma revisão na estrutura curricular do curso de Administração de Empresas da FEA-USP para sanar as deficiências detectadas por Vasconcellos e Mattar (1998) e Martins e Delatorre (1999):

- Necessidade de se contemplar mais disciplinas optativas especializantes;

- Necessidade de se contemplar mais disciplinas integrativas;

- Necessidade de se implementar a melhoria na didática dos professores (aspecto que teve maior destaque na segunda pesquisa). 
Em 1987 Pilão (p. 56) já mencionava a ausência quase total de tópicos ligados à dimensão internacional da Administração. Em 1997, Starr era tão favorável à idéia de internacionalização do currículo de APO que recomendava nas suas conclusões finais que, mesmo que não houvesse demanda de alunos por cursos de APO Internacionais, o próprio curso geraria esta demanda.

A ênfase em técnicas quantitativas e a distância entre APO e o planejamento estratégico são as principais dificuldades para a internacionalização do currículo de APO, mas Starr (1987) propõe três direcionadores lógicos para auxiliar nessa missão:

- Compartilhamento de responsabilidades entre Administração da cadeia de suprimentos e APO. "As escolhas globais envolvem uma série de opções de produtores para fabricação e montagem."

- Por um lado a administração de portfólio pode reduzir o risco pelo uso da diversificação geográfica e por outro a APO pode aumentar a eficiência centralizando as operações.

- Significantes diferenças competitivas operacionais podem ser obtidas pela Administração de Capacidades de APO (Capabilities management), por exemplo, entregas aceleradas, aproveitando as diferenças de fuso-horário para acelerar o desenvolvimento de produtos com equipes em vários países, ou seja, "sistemas capazes de produzir, vender e distribuir o produto, empregando a cooperação funcional em uma escala internacional".

Quanto ao conteúdo, a discussão sobre o desafio de se internacionalizar o currículo de APO pode ser estendida para a inclusão de tópicos emergentes, por exemplo, aqueles citados por Meredith e Roth (1998), que foram os tópicos com o maior números de artigos publicados em 1997:

- Administração da cadeia de suprimentos: com pesquisas em estratégias de otimização, melhoria do desempenho com o uso da informática, internet, terceirização, etc.

- Globalização: envolvendo questões estratégicas, operação de manufatura internacional, cadeias de suprimentos globais, decisões de localização, produtividade levando em conta as características de cada país como a inflação, desenvolvimento de produto e processo e transferência de tecnologias entre outras.

- Operações de serviços: principalmente por ser a maior fonte de PIB, pelo menos nas regiões desenvolvidas e estar passando por mudanças na forma de administrar, por 
exemplo, enfatizando os serviços existentes mesmo na manufatura, ou os conceitos de manufatura aplicáveis aos serviços, além das novas tecnologias como e-commerce.

O trabalho de Queiroz, Lucero e Borges (on line, 2001) teve foco no ensino de engenharia de sistemas de produção, mas a discussão é válida para o ensino de APO de um modo geral, por exemplo, quando cita o desafio de ensinar aspectos organizacionais (gerenciais) da fabricação mecânica, colocando os alunos face a face com os problemas do cotidiano (planejamento da produção, programação da produção e controle) num modelo realístico e abrangente. Para lidar com esse desafio, eles propõem o uso de jogos computacionais.

Finalmente, Luque e Machuca (2003) recomendam que deveriam ser identificadas as causas que levam os professores a darem preferência pelos métodos de ensinos tradicionais e tomar ações para o uso de técnicas mais modernas, privilegiando o autoaprendizado e o ensino à distância. 
CAPÍTULO 3

Metodologia da pesquisa 


\section{Metodologia da pesquisa}

Os objetivos desta pesquisa foram definidos de modo a convergir os esforços para o entendimento do ensino de APO. Na figura 3, eles são representados pelos quatro vetores, enquanto as setas (linhas curvas) indicam que houve uma comparação entre os resultados.

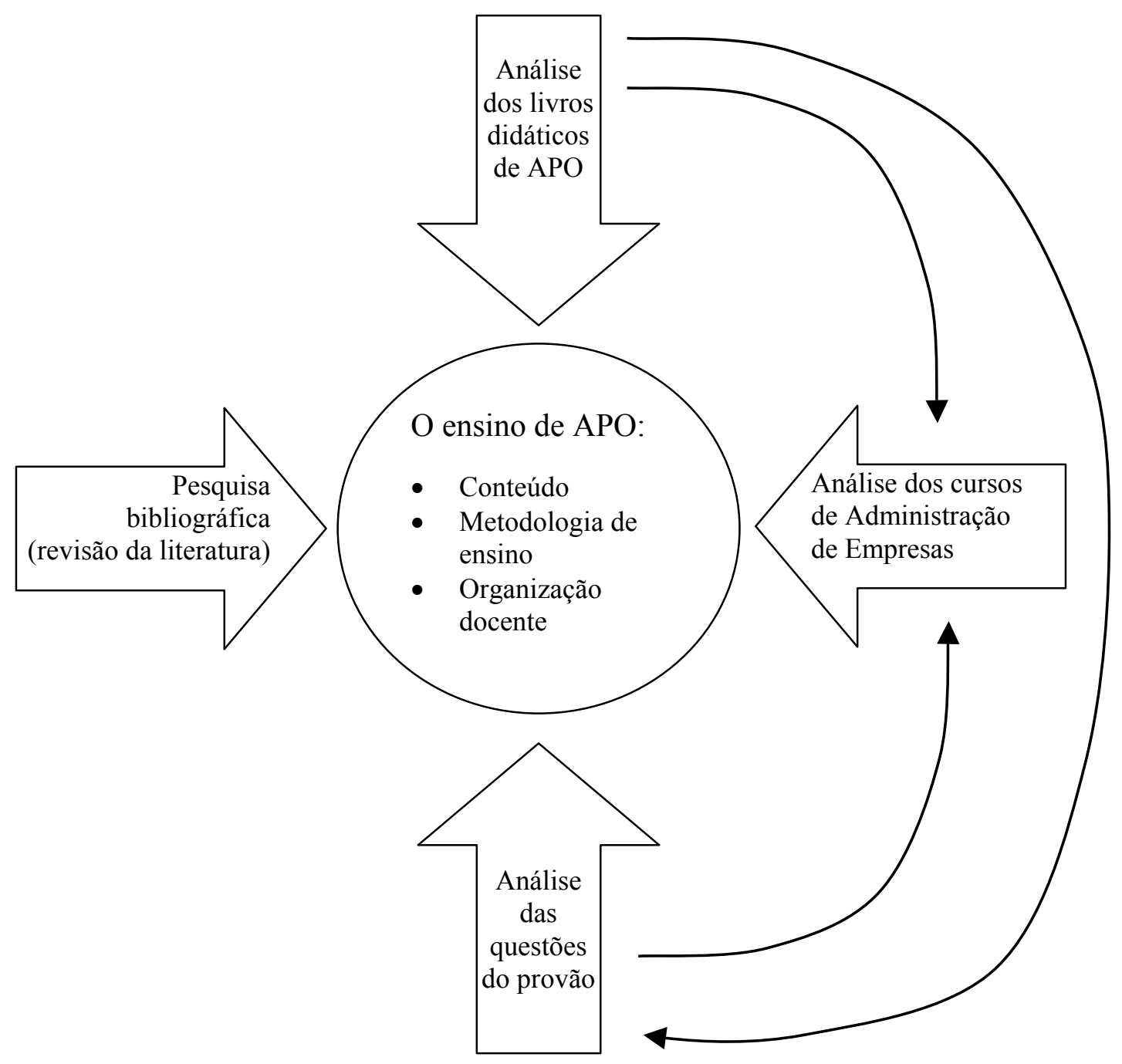

Figura 3: Vetores que orientaram a pesquisa

Para atingir cada um dos objetivos foi definido um método específico para o levantamento e análise de dados, que são descritos em detalhes nas próximas seções, como uma forma de evidenciar o esforço para garantia da validade interna da pesquisa. 


\subsection{Levantamento e análise dos livros didáticos de APO}

Para o ensino de APO há diversos livros disponíveis, alguns dedicados a assuntos mais específicos como: gestão da qualidade, logística, administração da cadeia de suprimentos, administração de recursos materiais e patrimoniais, gestão das operações de serviços, just-in-time e MRP, e outros livros mais abrangentes, que tratam dos vários assuntos da APO, como é o caso dos livros sugeridos pela ANGRAD (1999): Corrêa e Gianesi (1993), Martins e Laugeni (1998), Monks (1987), Moreira (1998) e Slack et al. (1997). Normalmente, esses livros têm nomes muito parecidos com Administração da produção, Gestão de operações ou Administração da produção e operações e são livros deste tipo que estamos interessados em analisar.

$\mathrm{Na}$ escolha dos livros que deveriam ser analisados, levaram-se em conta as seguintes questões:

- Quais livros foram recomendados pelo MEC em 1997?

- Quais livros foram recomendados pela ANGRAD em 1999?

- Quais livros estão disponíveis nas livrarias?

- Quais livros estariam disponíveis para análise?

As duas primeiras questões estão respondidas no capítulo 4, mas podemos antecipar que os livros recomendados pelo MEC e ANGRAD são de pelo menos cinco anos atrás, apesar disso, decidimos considerar todos os livros recomendados pela ANGRAD na fase de análise e de validação.

Para identificar quais livros estão disponíveis nas livrarias, foi feita uma busca pela Internet nos sites de grandes livrarias como: Cultura, Loyola, Nobel, Saraiva, Siciliano e Sodiler e editoras como: Atlas, Bookman, Campus, Edgard Blücher, Érica, FGV, Futura, LTC, Makron Books (Pearson Education), Manole, Pioneira Thomson, Qualitymark, Record, Saraiva e Vanzolini, e ainda sites de busca como $<\underline{\text { http://www.google.com.br }>\text { e }}$ $<$ http://www.buscape.com.br $>$. Desta forma foram obtidas dez referências: Contador (1998), Corrêa, Gianesi e Caon (2000), Davis, Aquilano e Chase (2001), Gaither e Frazier (2002), Krajewski e Ritzman (2003), Martins e Laugeni (1998), Meredith e Shafer (2002), Moreira (2000), Slack et al (2002) e Stevenson (2002). 
Através do empréstimo de livros das bibliotecas da FAC-FITO, FEA-USP, da UniFECAP e do próprio orientador foi possível conseguir todos os livros da lista que tinham sido identificados e até complementá-la com livros americanos atuais. No total, 18 livros foram comparados quanto aos seus conteúdos, estrutura e recursos de aprendizagem. No capítulo 4 são comentadas de forma detalhada a análise e a comparação dos livros.

A análise de freqüências foi utilizada para avaliar os tópicos de APO, que foram classificados em principais, secundários e opcionais, bem como as "lacunas de conteúdo" de cada livro.

Para validar essa análise, os resultados foram comparados com a inclusão de outros cinco livros: Martinich (1997), Dilworth (2000), Heizer e Render (1999), Corrêa, Gianesi e Caon (2000) e Monks (1987), o que não alterou as conclusões que tinham sido obtidas.

Finalmente foi verificada a presença de recursos de aprendizagem como: resumo, índice, estudos de caso, exercícios, CD-ROM, site do livro, pacote suplementar de recursos e o número de páginas. A análise de freqüências também auxiliou na identificação das principais características dos livros didáticos, comparação dos livros nacionais com os americanos e ainda comparar os livros mais atuais (editados após o ano 2000) com os mais antigos. 


\subsection{Levantamento e análise do Provão de Administração de Empresas}

A identificação dos conteúdos de APO que têm sido cobrados no Provão foi uma tarefa relativamente simples, mas que demandou alguns cuidados que são explicados nas etapas descritas a seguir:

- Obter as provas de 1996 a 2003, seus gabaritos, padrões de respostas, diretrizes e outros informativos e documentos que estivessem disponíveis no INEP (on line, 2004b);

- Identificar as questões de APO em cada prova:

Para o exame de 2003 o INEP divulgou em seu site a "Tabela de Especificação de Habilidades e Conteúdos", que relaciona as matérias envolvidas em cada questão. Para os anos 2001 e 2002, foram obtidos com alguns amigos, que são coordenadores de curso de graduação em Administração, uma cópia do questionário que o INEP usa para avaliar o grau de dificuldade de cada questão e que também relaciona as matérias de cada questão.

As provas dos anos anteriores não foram usadas na análise por três motivos: em primeiro lugar, porque o resultado obtido com os três últimos anos já forneceu uma boa base para concluir sobre os conteúdos de APO que têm sido cobrados no Provão; em segundo lugar, porque não estavam disponíveis documentos do INEP que relacionassem as matérias para cada questão. Assim, ter-se-ia que classificar ao modo do autor as questões que deveriam ser consideradas como de APO, podendo divergir dos critérios usados pela comissão do INEP. A título de exemplo das divergências que se procura evitar, cita-se a classificação feita por Moreira (1999, p. 98 - 99). Para a prova de 1996, o INEP classificou duas questões discursivas em seu Padrão de resposta esperado como envolvendo disciplina/conteúdo de APO, porém Moreira não considerou nenhuma delas como de APO. Para a prova de 1997 ocorreu a mesma divergência, o INEP classificou uma questão discursiva como de APO e Moreira nenhuma. Para o ano de 1998 o INEP classificou duas questões objetivas como de Administração da Produção e duas de Administração de Recursos Materiais, enquanto Moreira classificou quatro como sendo de APO, uma mista de APO/Marketing e três mistas APO/Finanças e, finalmente, o último motivo e que por si só seria suficiente para justificar a análise das provas de 2000 a 2003: Moreira (1999) já tinha feito uma análise semelhante das provas de 1996 a 1999 com a seguinte conclusão: "Em termos de currículo específico de APO, portanto, o Provão não parece ser de grande valia para apontar tópicos de importância maior." 
- A primeira análise foi quantitativa para comparar o número de questões de APO em relação às outras matérias de formação profissional e a evolução a cada ano.

- Na segunda análise, cada questão de APO foi relacionada com o conteúdo específico de APO que estava sendo exigido e, finalmente, conseguiu-se uma lista de tópicos, que foram comparados com a lista de tópicos principais, obtida na análise dos livros didáticos (triangulação). Os resultados da análise dos livros didáticos e do Provão foram coerentes entre si.

\subsection{Levantamento e análise dos cursos de Administração de Empresas}

Dizem que o título é a parte da tese que passa pelo maior número de revisões e neste caso o mesmo também se aplica à escolha das escolas que deveriam ser incluídas na pesquisa de campo. No projeto da tese havia uma idéia mal formulada de se usar uma estratégia do tipo bola de neve (uma escola indicaria a outra) e no exame de qualificação houve duas sugestões: avaliar apenas a FEA-USP ou comparar a FEA-USP com a FGVEAESP.

Como um objetivo da tese desde a fase de projeto era pesquisar o ensino de APO nas grandes escolas de Administração da cidade de São Paulo, decidiu-se acatar a sugestão da banca de qualificação, mas também incluir a FEA-PUC-SP. A escolha das três escolas é quase óbvia, mas é importante mencionar que foram levados em conta vários fatores:

- a importância dessas escolas em nível nacional e até internacional,

- a existência de uma Área ou Departamento de Administração da Produção em sua estrutura,

- das 68 IES's do município de São Paulo que participaram do Provão em 2003, foram destacadas no quadro 2 as cinco escolas que obtiveram oito "A" consecutivos. Estas escolas podem ser separadas em dois grupos tanto pela porcentagem de alunos no $4^{\circ}$ quartil de notas de graduandos do Brasil, quanto pela avaliação feita pelo Guia do Estudante (2004). No primeiro grupo têm-se a FEA-USP e a FGV-EAESP, e no segundo grupo a FAAP, FEA-PUC-SP e ESPM,

- em nível de pós-graduação, a FGV-EAESP e a FEA-USP possuem cursos de mestrado e doutorado em Administração e a FEA-PUC-SP possui curso de mestrado, enquanto a FAAP e a ESPM não possuem cursos de mestrado ou doutorado. 
- nos últimos oito anos, 3414 alunos se graduaram pela FEA-PUC-SP, enquanto a FAAP e ESPM juntas graduaram 3528 alunos.

Da forma como foi feita a escolha, fica reforçada a idéia de que não há interesse em generalizar os resultados para as demais escolas de Administração, mas sim estabelecer um benchmarking, que pudesse ser considerado pelas demais escolas no momento de suas auto-avaliações ou de seus planejamentos. 
Quadro 2: Instituições de Ensino Superior com oito "A" no Provão

\begin{tabular}{|c|c|c|c|c|c|c|c|c|c|}
\hline \multirow{2}{*}{ Instituição } & \multicolumn{4}{|c|}{ Graduandos por ano } & \multicolumn{4}{|c|}{$\begin{array}{l}\text { Percentual de alunos da IES no } \\
\text { grupo delimitado pelo } 4^{\circ} \text { quartil de } \\
\text { notas dos graduandos do Brasil }\end{array}$} & \multirow{2}{*}{$\begin{array}{l}\text { Guia do } \\
\text { estudante } \\
\mathbf{2 0 0 4}\end{array}$} \\
\hline & 2000 & 2001 & 2002 & 2003 & 2000 & 2001 & 2002 & 2003 & \\
\hline $\begin{array}{l}\text { Faculdade de Economia, Administração e } \\
\text { Contabilidade da Universidade de São Paulo } \\
\text { (FEA-USP) }\end{array}$ & 128 & 164 & 209 & 190 & $91,4 \%$ & $92,7 \%$ & $93,8 \%$ & $92,6 \%$ & 5 estrelas \\
\hline $\begin{array}{l}\text { Escola de Administração de Empresas de } \\
\text { São Paulo da Fundação Getúlio Vargas } \\
\text { (FGV-EAESP) }\end{array}$ & 383 & 337 & 394 & 361 & $85,1 \%$ & $83,7 \%$ & $90,1 \%$ & $91,4 \%$ & 5 estrelas \\
\hline $\begin{array}{l}\text { Faculdade de Administração da Fundação } \\
\text { Armando Álvares Penteado (FAAP) }\end{array}$ & 354 & 266 & 435 & 462 & $68,1 \%$ & $73,7 \%$ & $63,7 \%$ & $59,3 \%$ & 4 estrelas \\
\hline $\begin{array}{l}\text { Faculdade de Economia, Administração, } \\
\text { Contabilidade e Atuária da Pontifícia } \\
\text { Universidade Católica de São Paulo } \\
\text { (FEA-PUC-SP) }\end{array}$ & 457 & 419 & 405 & 427 & $55,6 \%$ & $52,5 \%$ & $58,3 \%$ & $52,5 \%$ & 4 estrelas \\
\hline $\begin{array}{l}\text { Escola Superior de Propaganda e Marketing } \\
\text { (ESPM) }\end{array}$ & 88 & 129 & 235 & 239 & $53,4 \%$ & $58,9 \%$ & $51,5 \%$ & $51,9 \%$ & 4 estrelas \\
\hline
\end{tabular}

Fonte: Elaborado pelo autor com os dados disponíveis em INEP (on line, 2004c) e GUIA (2004). 
A coleta de dados sobre o conteúdo de APO, metodologias de ensino e a organização do corpo docente, baseou-se principalmente na triangulação dos dados obtidos através de documentos como grade curricular e os programas (currículo), contato com pessoal da secretaria e questionários respondidos pelos professores, como é apresentado no quadro 3 e detalhado no apêndice $B$.

Quadro 3: Questões e fontes de informação sobre os conteúdos, metodologias de ensino e organização do corpo docente.

\begin{tabular}{|c|c|}
\hline FONTE & INFORMAÇÃO - QUESTÕES \\
\hline $\begin{array}{l}\text { DOC - Grade curricular ou } \\
\text { estrutura curricular } \\
\text { (disciplinas de cada } \\
\text { semestre) }\end{array}$ & $\begin{array}{l}\text { - } \mathrm{N}^{\mathrm{o}} \text { de horas / disciplinas } \\
\text { - } \% \text { horas para APO no curso de Administração } \\
\text { - Em quais semestres é dado APO? } \\
\text { - Quais os pré-requisitos para as disciplinas de APO? } \\
\text { - Quais disciplinas de APO são obrigatórias e eletivas? }\end{array}$ \\
\hline $\begin{array}{l}\text { DOC - Ementas, plano de } \\
\text { ensino ou programa de aula }\end{array}$ & $\begin{array}{ll}\text { - } & \text { Conteúdos } \\
\text { - } & \text { Bibliografia utilizada } \\
\text { - } & \text { Método de ensino } \\
\text { - } & \text { Sistema de avaliação }\end{array}$ \\
\hline $\begin{array}{l}\text { Buscas na Homepage da } \\
\text { escola e do curso, Secretaria, } \\
\text { coordenação, professores } \\
\text { (contato telefônico, por } \\
\text { e-mail e pessoalmente). }\end{array}$ & 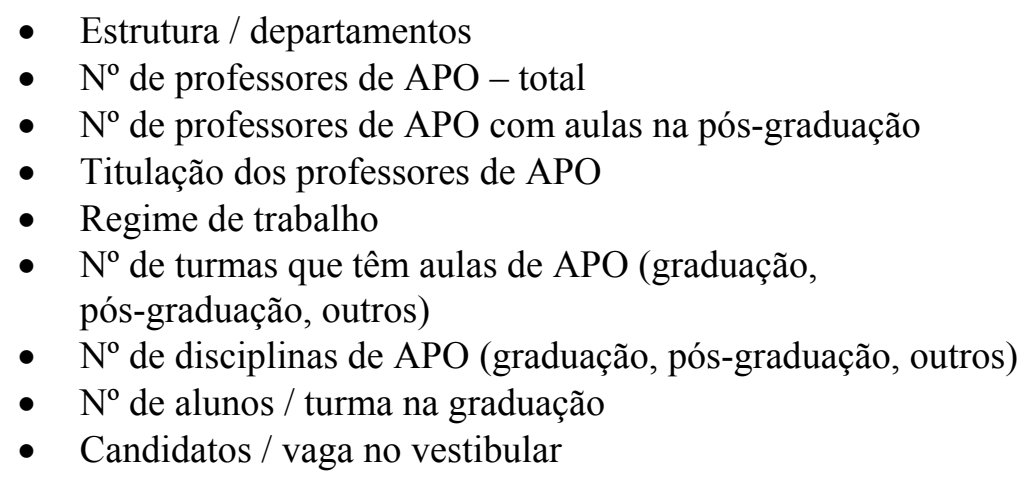 \\
\hline Email - Professores de APO & $\begin{array}{l}\text { - } \text { Método de ensino (aulas expositivas, visitas, palestras, casos, } \\
\text { - } \text { jogos, simulação,...) } \\
\text { - } \text { Sistema de avaliaçãa } \\
\text { - Regime de trabalho. } \\
\text { - Influência do Provão no método de ensino, sistema de } \\
\text { avaliação ou no conteúdo de APO. }\end{array}$ \\
\hline
\end{tabular}

Para cada escola, o levantamento de dados iniciou-se com buscas pela Internet, com os dados sendo confirmados posteriormente junto à secretaria e professores. Os dados foram sendo analisados conforme a coleta prosseguia, de modo que a todo momento 
verificavam-se as mesmas informações em fontes diferentes (contato telefônico, e-mail, entrevista, homepage ou documentos fornecidos pelos informantes).

Numa segunda etapa da coleta de dados, contataram-se todos os professores de APO que estavam ministrando aulas na graduação, solicitando respostas para o questionário (APÊNDICE B).

As informações coletadas foram suficientes para comparar os três cursos, quanto à estrutura curricular, o conteúdo de APO, a metodologia de ensino e sistema de avaliação e a organização do corpo docente e numa segunda etapa de análise, esses resultados foram comparados com os resultados da análise dos livros didáticos e do Provão.

Finalmente os resultados foram apresentados para um professor de cada escola com o objetivo de melhorar a exatidão e validar as conclusões. Cada reunião teve uma duração média de noventa minutos.

\subsection{Limitações, validade interna e externa}

Na pesquisa qualitativa, a principal limitação é que não há um método particular para a coleta de dados e para a avaliação da precisão da análise dos dados, a análise depende muito do pesquisador, ou como é apresentado repetidamente por Merriam (1998, p. 19, 34, 36, 39, 52): “O pesquisador é o instrumento primário para coleta e análise de dados".

Por este mesmo motivo, Patton (1990, p. 472) recomenda que no relatório de pesquisa sejam incluídas informações sobre o pesquisador: experiência, treinamento, ligações que o pesquisador tenha com as pessoas ou IES's em estudo. "O princípio é relatar qualquer informação pessoal ou profissional que possa ter algum efeito sobre a coleta de dados, análise e interpretação". Wolcott (1990, p. 80) sugere que seja dado ênfase na experiência que o pesquisador tenha com o tema. Por esses motivos foi elaborado o APÊNDICE C, que apresenta essas informações. 
Para os cursos de Administração foram utilizadas entrevistas, contatos telefônicos e por e-mail, além de documentos, mas o levantamento de dados através da observaçãoparticipante poderia resultar em descrições mais detalhadas e com nuanças que a entrevista ou a análise documental não são capazes de detectar, ainda assim, a limitação permaneceria. $^{8}$

O estudo ficaria mais completo se levasse em conta a opinião dos práticos em APO, por exemplo, de executivos, gerentes e diretores, trabalhando na indústria ou em serviços, de origem governamental ou não, bem como a opinião dos alunos. Essa limitação poderá ser sanada com uma pesquisa especifica que complemente este trabalho, o que será enfatizado novamente na seção dedicada às recomendações.

A triangulação das fontes de informação e a preparação do pesquisador foram as principais providências tomadas para garantir a validade interna da pesquisa, mas a qualificação do projeto de tese também foi uma atividade muito importante para a melhoria da qualidade da pesquisa, tornando-a mais objetiva e focada.

Quanto à generalização (validade externa), tanto para outras IES's, quanto no tempo, cabe ao próprio leitor decidir se os resultados representam a sua realidade, o que é típico da maioria das pesquisas qualitativas e daquelas em que a amostragem é intencional. Já foi comentado na escolha dos cursos de Administração que eles não representam uma "amostra", e sim que foram escolhidos justamente por representarem os melhores cursos de Administração do município de São Paulo. Com relação ao tempo, também já foi comentado que a disciplina de APO é dinâmica, então é justificável que pesquisas semelhantes sejam feitas num futuro próximo, o que será explicado com mais detalhes na seção 6.2 .

8 Patton (1990, p. 208) cita o exemplo de um pesquisador que estava numa prisão para ter uma visão "de dentro", buscando saber como é estar preso. Um dos presidiários demonstra a impossibilidade de o pesquisador saber como é estar preso, porque ele tinha a liberdade de ir para sua casa quando quisesse. 


\section{CAPÍTULO 4}

O conteúdo de APO e os recursos de aprendizagem do ponto de vista dos livros didáticos 


\section{O conteúdo de APO e os recursos de aprendizagem do ponto de vista dos livros didáticos}

Apesar de desatualizada, ainda é possível obter a "Biblioteca básica para os cursos de graduação em Administração", que lista os livros e periódicos recomendados pela comissão de especialistas de ensino de Administração da Secretaria de Educação Superior do MEC (BRASIL on line, 1997?). A análise desta "bibliografia básica" se baseou nas tabelas 2 e 3, que são comentadas a seguir. 
Da bibliografia recomendada para Administração da Produção (tabela 2), metade tem mais de dez anos e o período de 1993 a 1994 representa 31\% do total de referências. As referências mais novas são de 1996 e as mais antigas são:

- BARNES, R. M.. Estudo de movimentos e de tempos: projeto e medida do trabalho. São Paulo: Fundação Getúlio Vargas, 1977.

- $\quad$ LINK, H. Programação e controle da produção. São Paulo : Edgard Blücher, 1977.

Tabela 2: Distribuição por ano de edição dos livros de Administração da Produção recomendados na "Biblioteca básica"

\begin{tabular}{cccc}
\hline Edição & Quantidade & \% & \% acum \\
\hline 1977 a 1980 & 3 & $2,52 \%$ & $2,52 \%$ \\
\hline 1981 a 1982 & 4 & $3,36 \%$ & $5,88 \%$ \\
\hline 1983 a 1984 & 3 & $2,52 \%$ & $8,40 \%$ \\
\hline 1985 a 1986 & 3 & $2,52 \%$ & $10,92 \%$ \\
\hline 1987 a 1988 & 10 & $8,40 \%$ & $19,33 \%$ \\
\hline 1989 a 1990 & 14 & $11,76 \%$ & $31,09 \%$ \\
\hline 1991 a 1992 & 21 & $17,65 \%$ & $48,74 \%$ \\
\hline 1993 a 1994 & 37 & $31,09 \%$ & $79,83 \%$ \\
\hline 1995 a 1996 & 24 & $20,17 \%$ & $100,00 \%$ \\
\hline TOTAL & 119 & $100,00 \%$ & \\
\hline
\end{tabular}

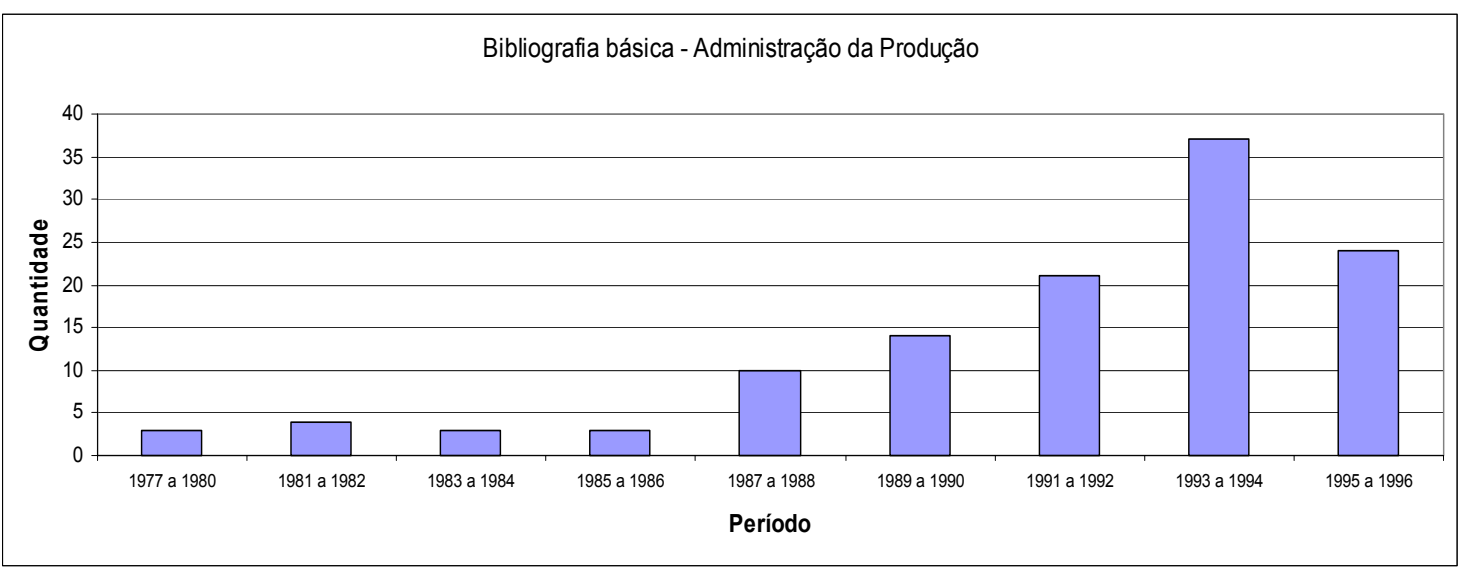


Da bibliografia recomendada para Recursos Materiais e Patrimoniais (tabela 3), observa-se que a maior parte (73\%) das referências tem mais de dez anos e as recomendações mais antigas são:

- $\quad$ ARAÚJO, J. S. de. Administração de materiais. São Paulo: Atlas, 1974.

- CASADEVANTE Y MUYICA, J. L. F. A armazenagem na prática. São Paulo: Pórtico, 1974.

Tabela 3: Distribuição por ano de edição dos livros de Recursos Materiais e Patrimoniais recomendados na "Biblioteca básica"

\begin{tabular}{cccc}
\hline Edição & Quantidade & \% & \% acum \\
\hline 1974 a 1980 & 7 & $20,59 \%$ & $20,59 \%$ \\
\hline 1981 a 1982 & 2 & $5,88 \%$ & $26,47 \%$ \\
\hline 1983 a 1984 & 6 & $17,65 \%$ & $44,12 \%$ \\
\hline 1985 a 1986 & 1 & $2,94 \%$ & $47,06 \%$ \\
\hline 1987 a 1988 & 2 & $5,88 \%$ & $52,94 \%$ \\
\hline 1989 a 1990 & 7 & $20,59 \%$ & $73,53 \%$ \\
\hline 1991 a 1992 & 0 & $0,00 \%$ & $73,53 \%$ \\
\hline 1993 a 1994 & 3 & $8,82 \%$ & $82,35 \%$ \\
\hline 1995 a 1996 & 6 & $17,65 \%$ & $100,00 \%$ \\
\hline TOTAL & 34 & $100,00 \%$ & \\
\hline
\end{tabular}

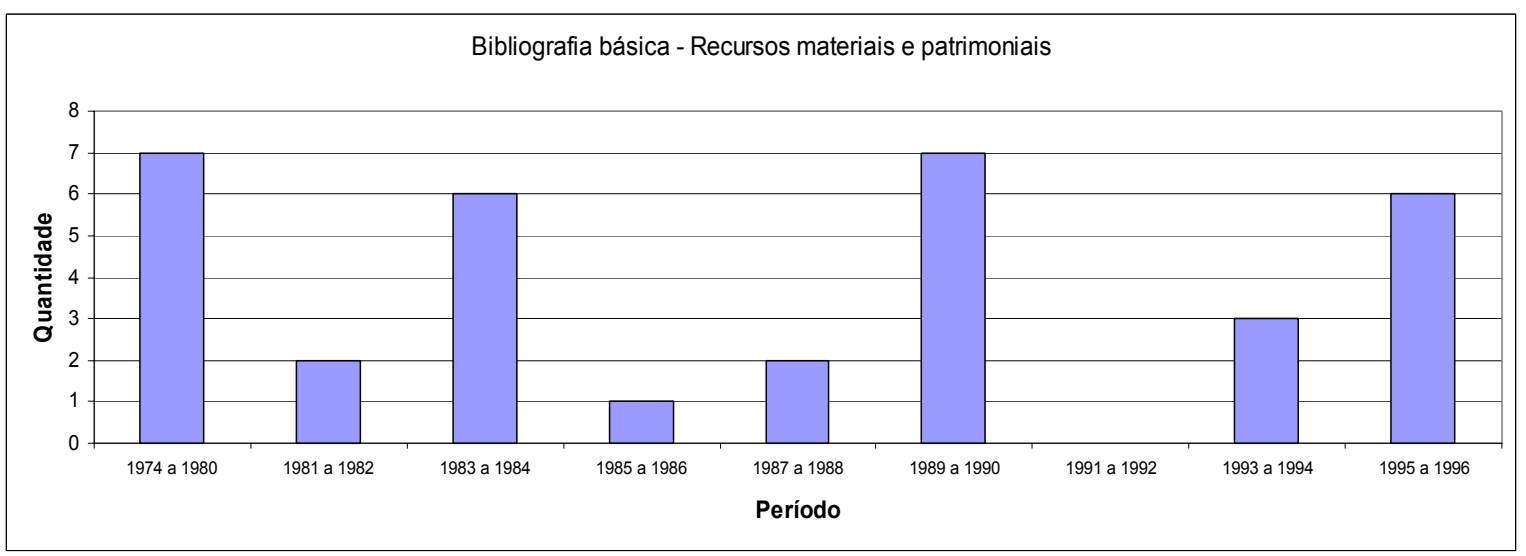


Reconhecendo a necessidade de uma bibliografia sucinta e atual, a ANGRAD executou uma pesquisa que foi divulgada em 1999 com o objetivo de levantar a bibliografia essencial para cada disciplina do curso de Administração, levando em conta a facilidade de acesso e a consulta ao maior número possível de professores. A seguir, apresentamos os resultados para as disciplinas da área de APO (ANGRAD on line, 1999).

Administração da Produção:

CORREAA, Henrique L.; GIANESI, Irineu G. N. Just-in-time, MRP II e OPT: um enfoque estratégico. $2^{\text {a }}$ Ed. São Paulo: Ed. Atlas, 1993.

MARTINS, Petrônio G.; LAUGENI, Fernando. P. Administração da produção. São Paulo: Ed. Saraiva, 1998.

MONKS, Joseph G. Administração da produção. São Paulo: Ed. Makron, 1987.

MOREIRA, Daniel A. Administração da produção e operações. São Paulo: Ed. Pioneira, 1998. (reimpressão do original de 1993).

SLACK, Nigel. Vantagem competitiva em manufatura. São Paulo: Ed. Atlas, 1998.

SLACK, Nigel; et al. Administração da produção. São Paulo: Ed. Atlas, 1997.

Administração da qualidade e novas abordagens

ARNOLD, Kenneth L. O guia gerencial para a ISO 9000. Rio de Janeiro: Ed. Campus, 1995.

CAJAZEIRA, Jorge E. R. ISO 14001 - Manual de implantação. Rio de Janeiro: Ed. Qualitymark, 1997.

DEMING, W. E. Qualidade: a revolução da administração. Rio de Janeiro: Ed. Saraiva, 1990.

JURAN, J. M. Juran - planejamento para a qualidade. São Paulo: Ed. Pioneira, 1995.

SCHERKENBACH, William W. O caminho de Deming para a melhoria contínua. Rio de Janeiro: Ed. Qualitymark, 1993. 
Já se passaram quatro anos desde a bibliografia sugerida pela ANGRAD e nesse período vários livros da área de APO foram traduzidos e revisados. Para citar pelo menos um exemplo de como os autores têm mantido as suas obras atualizadas, será comentado o livro "Administração da Produção" de SLACK et al., que teve sua edição original em 1995 e foi editado pela primeira vez no Brasil em 1997, sendo atualizado em 2002. Nesta segunda edição foi mantida a estrutura dos capítulos:

1. Administração da produção

2. Papel estratégico e objetivos da produção

3. Estratégia da produção

4. Projeto em gestão de produção

5. Projeto de produtos e serviços

6. Projeto da rede de operações produtivas

7. Arranjo físico e fluxo

8. Tecnologia de processo

9. Projeto e organização do trabalho

10. Natureza de planejamento e controle

11. Planejamento e controle de capacidade

12. Planejamento e controle de estoque

13. Planejamento e controle da cadeia de suprimentos

14. MRP

15. Planejamento e controle just in time

16. Planejamento e controle de projetos

17. Planejamento e controle de qualidade

18. Melhoramento da produção

19. Prevenção e recuperação de falhas

20. Administração da qualidade total

21. Desafio da produção

Pela análise dos sumários das duas edições, foi possível avaliar as novas ênfases que SLACK et al. deram ao livro com o objetivo de ajustá-lo aos temas atuais. Algumas revisões são encontradas em vários capítulos, por exemplo:

- No capítulo 1 foram acrescentadas: A administração da produção em pequenas empresas e em organizações sem fins lucrativos.

- No capítulo 3 foram incluídos vários tópicos que pertenciam ao capítulo 21 na $1^{\mathrm{a}}$ edição.

\footnotetext{
9 É interessante observar que o título original é "Operations management", que talvez seja mais adequado ao que é tratado no conteúdo. Dos livros indicados pela ANGRAD, este foi o que teve revisão mais recente.
} 
- No capítulo 4 foi incluído o tópico projeto ecológico.

- No capítulo 5 foi incluída a prototipagem virtual.

- No capítulo 9 foram incluídos o trabalho em equipe e o trabalho flexível.

- No capítulo 13 foram incluídos: foco na satisfação efetiva dos consumidores finais e operações virtuais.

- No capítulo 19 foi incluída a manutenção centrada em confiabilidade.

- O último capítulo foi totalmente renovado incluindo temas como globalização, responsabilidade social e ambiental. Este capítulo demonstra o esforço dos autores para manter atualizada a sua obra e fornece uma orientação aos tópicos emergentes que podem ser discutidos em aula facilmente, dado que o material já está pronto. Para tornar mais evidente este comentário, é apresentada no quadro 4 uma comparação do capítulo 21 de cada edição. 
Quadro 4: Comparação entre o capítulo 21 - Desafio da produção - da $1^{\mathrm{a}}$ e $2^{\mathrm{a}}$ edição do livro Administração da Produção de SLACK et al.

\begin{tabular}{|c|c|}
\hline SLACK et al, 1997 & SLACK et al, 2002 \\
\hline 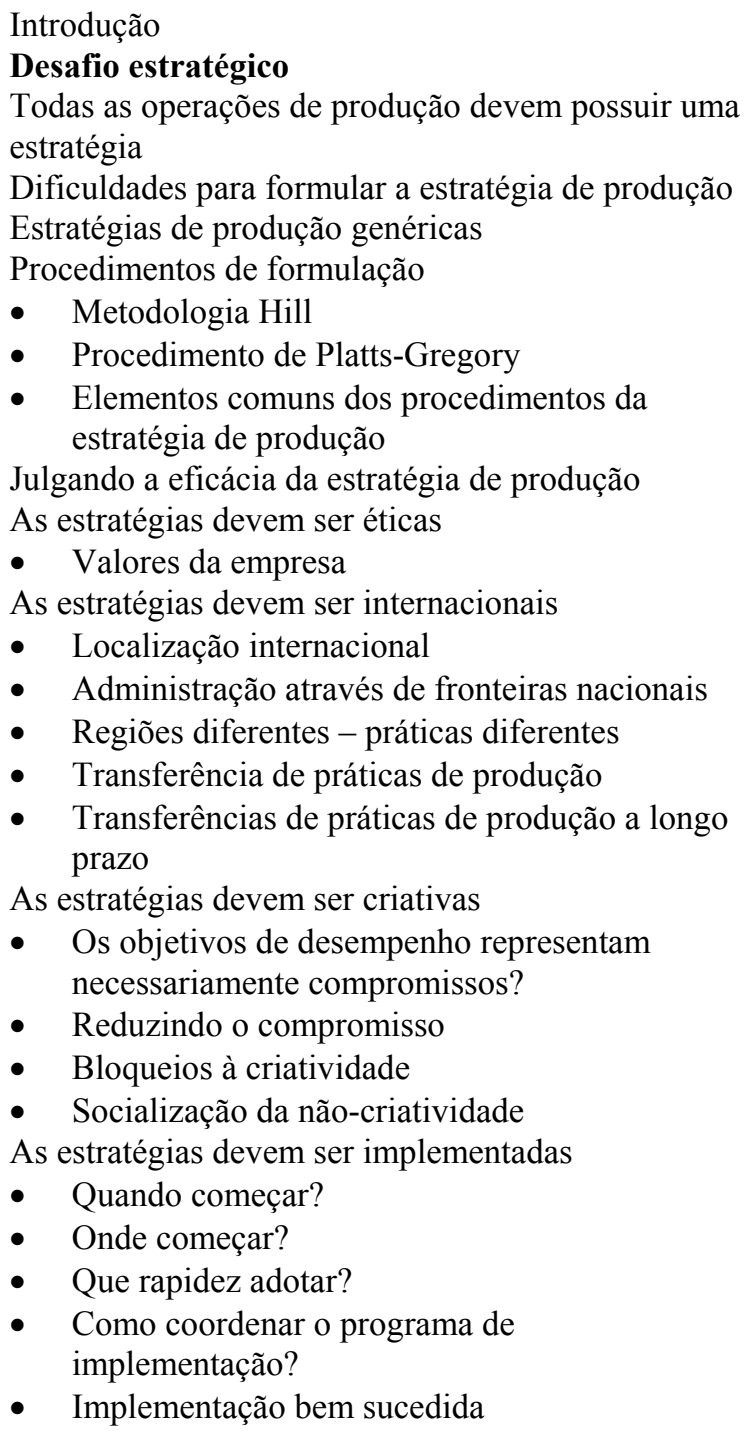 & $\begin{array}{l}\text { Introdução } \\
\text { Globalização } \\
\text { - } \quad \text { Globalização e decisões das operações } \\
\text { - } \quad \text { Movimento anti-globalização } \\
\text { - } \quad \text { Localização internacional } \\
\text { Responsabilidade social } \\
\text { Responsabilidade ambiental } \\
\text { - } \quad \text { Equilíbrio ambiental } \\
\text { - } \quad \text { Decisões operacionais e responsabilidade } \\
\text { - } \quad \text { Relatório verde } \\
\text { - } \quad \text { ISO 14000 } \\
\text { - } \quad \text { Administração da qualidade e administração } \\
\text { Tecnologia } \\
\text { - } \quad \text { Tecnologia como fonte de vantagem } \\
\text { - } \quad \text { Tempetitiva } \\
\text { - } \quad \text { Concelogia nas áreas de decisão de } \\
\text { Gestão do conhecimento de } \\
\text { - } \quad \text { A gestão do conhecimento está na moda } \\
\text { - Administração da produção e gestão do } \\
\text { - Conhecimento } \\
\text { - Conhecimento explícito e conhecimento } \\
\text { implícito } \\
\text { Criação do conhecimento } \\
\text { adividade }\end{array}$ \\
\hline
\end{tabular}

O objetivo até este ponto foi o de mostrar que os livros didáticos da área de APO têm sido revisados constantemente e que qualquer "bibliografia recomendada" também deveria passar por revisões periódicas. Apesar dessa "obsolescência crônica", é apresentada nessa seção uma comparação dos conteúdos de alguns livros didáticos de APO disponíveis neste momento.

É necessário destacar que está sendo considerado como "livro didático de APO” os livros que tratam de vários tópicos de $\mathrm{APO}$, por isso, normalmente sua extensão é superior a 500 páginas e seu próprio título é APO ou algo semelhante. Apesar de também serem 
“didáticos", não foram analisados livros mais específicos como: Gestão da qualidade ou Administração de recursos materiais e patrimoniais, entre tantos outros.

Para classificar um livro como mais adequado que outro, deveriam ser levadas em consideração várias questões, por exemplo: Em quais disciplinas será usado? Qual a duração do curso? Quais as características dos alunos? Qual o método de ensino utilizado? Qual o programa do curso? E até outros atributos do próprio livro, por exemplo, como foi feito por Alves (2003), que os classificou em seis categorias: conteúdo, estrutura, projeto gráfico, recursos de aprendizagem ou motivação do aluno, material para o professor e marketing editorial (do livro). Desta forma é necessário enfatizar que não se tem o objetivo de julgar a adequação dos livros para o ensino de APO, nos cursos Administração em nível de graduação, mas sim de compará-los entre si, identificando os tópicos que têm sido tratados de um modo geral.

Para proceder a análise, inicialmente foram selecionados oito livros na Língua Portuguesa (sendo três de autores brasileiros) e dez livros editados nos EUA ${ }^{10}$ :

Livros nacionais ou traduzidos:

[1] CONTADOR, José C. (Coord.). Gestão de operações. $2^{\mathrm{a}}$ Ed. São Paulo: Edgard Blücher, 1998.

[2] DAVIS, Mark M.; AQUILANO, Nicholas J.; CHASE, Richard B. Fundamentos da administração da produção. $3^{\mathrm{a}}$ Ed. Porto Alegre: Bookman, 2001.

[3] GAITHER, Norman; FRAZIER, Greg. Administração da produção e operações. $8^{\mathrm{a}}$ Ed. São Paulo: Pioneira-Thomson, 2002.

[4] MARTINS, Petrônio G.; LAUGENI, Fernando P. Administração da produção. São Paulo: Saraiva, 1998.

[5] MEREDITH, Jack R.; SHAFER, Scott M. Administração da produção para MBA's. Porto Alegre: Bookman Editora, 2002.

10 O livro de Krajewski e Ritzman (2002) foi traduzido neste ano, mas a edição analisada foi a americana mesmo. 
[6] MOREIRA, Daniel Augusto. Administração da produção e operações. São Paulo: Pioneira, 2000. (6 ${ }^{\mathrm{a}}$ reimpressão do original de 1993).

[7] SLACK, Nigel; CHAMBERS, Stuart; JOHNSTON, Robert. Administração da produção. $2^{\mathrm{a}}$ Ed. São Paulo: Ed. Atlas, 2002.

[8] STEVENSON, William J. Administração das operações de produção. $6^{\mathrm{a}} \mathrm{Ed}$. Rio de Janeiro: LTC, 2002.

Livros americanos:

[9] EVANS, James R. Production/operations management: quality, performance and value. $5^{\text {th }}$ ed. Minneapolis: West Publishing Company, 1997.

[10] GREENE, James H. (ed.) Production and inventory control handbook: prepared under supervision of the handbook editorial board of the American Production and Inventory control society (APICS). $3^{\text {rd }}$ ed. USA: McGraw-Hill,1997.

[11] HANNA, Mark D.; NEWMAN, William. R. Integrated operations management: adding value for customers. $1^{\text {st }}$ ed. New Jersey: Prentice-Hall, Inc., 2001.

[12] KRAJEWSKI, Lee J.; RITZMAN, Larry P. Operations management: strategy and analysis. $6^{\text {th }}$ ed. New Jersey: Prentice Hall (Pearson Education, Inc.), 2002.

[13] MELNYK, Steven A.; DENZLER, David R. Operations management: a value-driven approach. USA: Mc-Graw Hill, 1996.

[14] MORTON, Thomas E. Production and operations management. Ohio: South-western College Publishing, 1999.

[15] NAHMIAS, Steven. Production and operations analysis. $4^{\text {th }}$ ed. New York: McGrawHill, 2001.

[16] REID, R. Dan; SANDERS, Nada R. Operations management. $3^{\text {rd }}$ ed. USA: John Wiley \& Sons, Inc., 2002.

[17] RUSSEL, Roberta S.; TAYLOR III, Bernard W. Operations management. $4^{\text {th }}$ ed. New Jersey: Prentice Hall (Pearson Education, Inc.), 2003.

[18] SCHROEDER, Roger G. Operations management: contemporary concepts. USA: McGraw-Hill, 2000. 
A análise comparativa foi feita na forma de matriz, que resultou no quadro 5. Os conteúdos foram categorizados ${ }^{11}$ à medida que os livros eram analisados, ou seja, o número de linhas no quadro 5 foi aumentando conforme novos conteúdos surgiam e depois estabilizou porque os novos livros começaram a repetir os mesmos tópicos. Os números em cada célula indicam os capítulos em que cada tópico foi citado e as células cinzas indicam que o tópico não foi tratado no respectivo livro ou foi comentado apenas superficialmente, como ocorre em alguns casos com os tópicos: confiabilidade, uso de simulação ou programação linear para a tomada de decisões, manutenção produtiva total (TPM) em sistemas JIT ou na implementação da TQM. Este procedimento também foi utilizado para a análise da estrutura e recursos de aprendizagem, que resultou no quadro 7.

Apesar de a categorização dar a idéia de homogeneidade entre os autores, é importante destacar que a profundidade com que cada tema é tratado varia muito, o que pode ser facilmente percebido pelo número de páginas que os autores dedicaram a cada assunto ou mesmo nos casos em que alguns autores incluem capítulos exclusivos para determinado assunto, enquanto outros apenas o comentam como um subitem em um tema mais abrangente.

Da comparação apresentada no quadro 5, algumas conclusões são imediatas:

- Todos os livros são extensos o suficiente para abordar vários tópicos da APO, por isso o mesmo livro pode ser usado em mais de uma disciplina.

- Cada livro tem uma característica particular e detalha mais alguns aspectos da APO, por isso os professores podem adotar mais de um livro como forma de um complementar os pontos fracos do outro.

- Os três livros brasileiros têm abordado todo o conteúdo dos livros traduzidos e americanos.

\footnotetext{
11 Ao longo do texto, para designar o conteúdo de APO foram usados termos como: tópico, assunto ou tema, que são entendidos neste momento como sinônimos.
} 


\section{Quadro 5: Conteúdos dos livros didáticos de APO}

\begin{tabular}{|c|c|c|c|c|c|c|c|c|c|c|c|c|c|c|c|c|c|c|}
\hline \multirow[b]{2}{*}{ Conteúdo de APO } & \multicolumn{8}{|c|}{ Livros nacionais e traduzidos } & \multicolumn{10}{|c|}{ Livros editados nos EUA } \\
\hline & 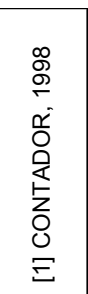 & 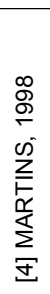 & 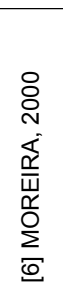 & 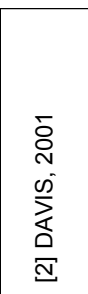 & 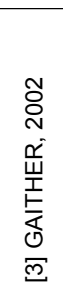 & 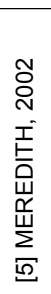 & 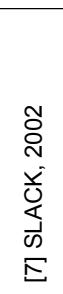 & 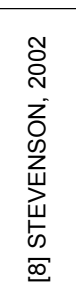 & 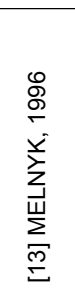 & 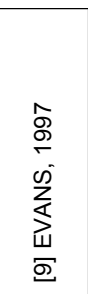 & 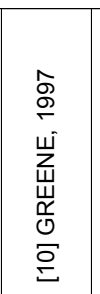 & 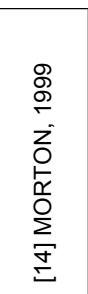 & 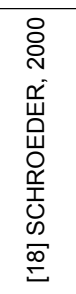 & 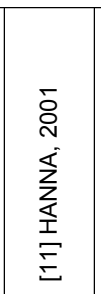 & 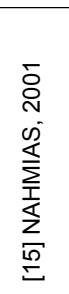 & 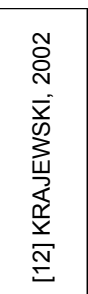 & 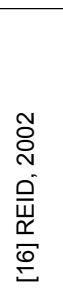 & 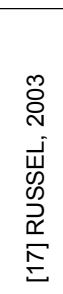 \\
\hline $\begin{array}{l}\text { Introdução a APO (histórico, importância, conceitos, produto X } \\
\text { serviço) }\end{array}$ & \begin{tabular}{cc|}
0 & 1 \\
17 & 32 \\
\end{tabular} & 1 & 1 & 1 & 1 & 1 & 1 & 1 & 1 & 1 & 123 & & 15 & $1 \mathrm{SA}$ & 1 & 1 & 1 & 12 \\
\hline Competitividade e estratégia de produçào & $\begin{array}{cc}2 & 3 \\
22 & 36\end{array}$ & 2 & 1 & 2 & 2 & 2 & 23 & 2 & 23 & 13 & 22 & & 2 & 3 & 1 & 12 & 2 & 2 \\
\hline Informações para a empresa & 8 & & & & & & & & & & & & & & & & & \\
\hline Métodos quantitativos: construção de modelos & & & 2 & & & & & & 4 & $1 \mathrm{~A}$ & 3436 & & & & & & & \\
\hline Métodos quantitativos: programação linear & & 9 & 3 & & & & & $5 \mathrm{~S}$ & & SD & 34 & 53 & & sc & S1 & SF & SB & $9 \mathrm{~s}$ \\
\hline Métodos quantitativos: modelo de transporte & & & $7 \mathrm{~S}$ & & & & & $8 S$ & & $8 \mathrm{SE}$ & 34 & 5253 & & sc & 6 & 914 & sc & 7 \\
\hline Métodos quantitativos: teoria da decisão & & & 5 & & 6 & & & $2 S$ & & SB & 34 & & & SB & & SA 8 & 9 & $2 S$ \\
\hline Métodos quantitativos: filas de espera (teoria das filas) & & & & $8 \quad 85$ & 12 & 6 & 11 & 19 & & sc & 34 & & & SF & s2 & SC & SA & 16 \\
\hline Métodos quantitativos: simulação & & & & & 12 & & & $19 S$ & & $14 \mathrm{SA}$ & 36 & & & & $\begin{array}{l}\text { S2 } \\
10\end{array}$ & SD & SD & $10 \mathrm{~S}$ \\
\hline Métodos quantitativos: estatística básica & & & 4 & & & & & & & & 35 & & & & & & & \\
\hline Métodos quantitativos: confiabilidade & & 20 & 8 & 5 & 16 & 4 & 19 & $44 S$ & & 6 & 26 & & & & 12 & & & 3 \\
\hline Engenharia econômica (ponto de equilíbrio, VPL, Depreciação...) & 56 & 5 & 67 & $3 \mathrm{~s}$ & 46 & 6 & 6 & 58 & 4 & 111 & 27 & $\begin{array}{c}2251 \\
53\end{array}$ & & 7 & 1 & $\begin{array}{c}\text { SA } 9 \\
\text { SK }\end{array}$ & 3 & 4 \\
\hline $\begin{array}{l}\text { Contabilidade geral, Administração financeira, Contabilidade de } \\
\text { custos }\end{array}$ & $\begin{array}{l}2425 \\
2637\end{array}$ & & & & & & & & & & & & & & & & & \\
\hline Planejamento e controle da capacidade & & 5 & 6 & 7 & 6 & 6 & 11 & 5 & 15 & 7 & 10 & 52 & 12 & 812 & 17 & 8 & 9 & 9 \\
\hline
\end{tabular}


Quadro 5: Conteúdos dos livros didáticos de APO (continuação)

\begin{tabular}{|c|c|c|c|c|c|c|c|c|c|c|c|c|c|c|c|c|c|c|}
\hline \multirow[b]{2}{*}{ Conteúdo de APO } & \multicolumn{8}{|c|}{ Livros nacionais e traduzidos } & \multicolumn{10}{|c|}{ Livros editados nos EUA } \\
\hline & 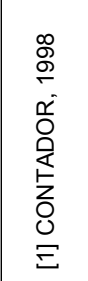 & 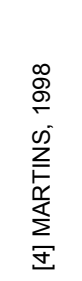 & 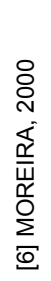 & 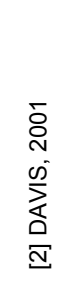 & 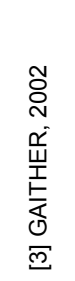 & 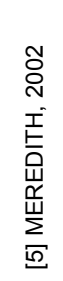 & 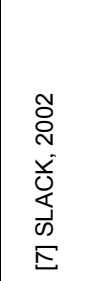 & 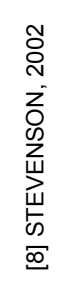 & 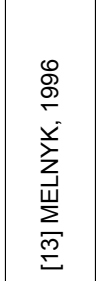 & 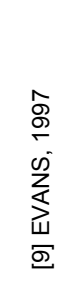 & 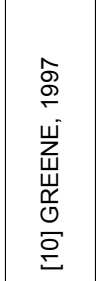 & 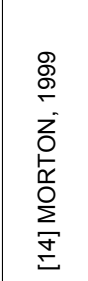 & 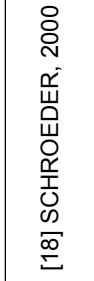 & 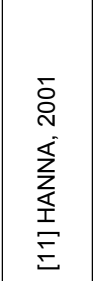 & 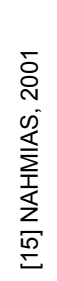 & 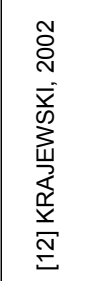 & 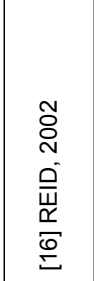 & 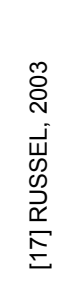 \\
\hline Curvas de aprendizagem & & & 6 & & & 6 & & $7 S$ & 6 & 7 & 8 & 52 & & & 1 & $\mathrm{SH}$ & 11 & 17 \\
\hline Localização & & 5 & 7 & 7 & 6 & 6 & 6 & 8 & 15 & 8 & & 52 & & 8 & 10 & 9 & 9 & $5 S$ \\
\hline Marketing industrial & 30 & & & & & & & & & & & & & & & & & \\
\hline Projeto do produto / serviço & $\begin{array}{c}2930 \\
34\end{array}$ & 3 & 8 & 3 & 416 & 4 & 45 & 4 & 11 & 6 & 626 & & 35 & 4 & 11 & & 3 & 3 \\
\hline Projeto do processo (seleção, desenvolvimento) & & 3 & 8 & 3 & 416 & 5 & 46 & 5 & 12 & 9 & 46 & & $\begin{array}{rl}45 & 5 \\
7\end{array}$ & 47 & & 3 & 3 & 4 \\
\hline Gestão por processos & 4 & & & 4 & & 1 & 118 & & 5 & & 32 & & 7 & 1 & & 3 & & 4 \\
\hline Arranjo físico (layout) & 12 & 6 & 9 & 7 & 7 & 5 & 7 & 6 & 12 & 10 & & 52 & 617 & 9 & 10 & 10 & 10 & 5 \\
\hline Tecnologia (informaçào, produção, processo, CAD, CAM, CIM...) & 7 & $\begin{array}{l}1314 \\
1518\end{array}$ & $8 S$ & 2 & 5 & 45 & $\begin{array}{c}58 \\
21\end{array}$ & 45 & $\begin{array}{cc}11 & 12 \\
19\end{array} \mid$ & 9 & $\mid \begin{array}{cc}8 & 17 \\
28 & 29 \\
30 & 31\end{array}$ & 34 & 6 & 47 & 10 & $5 \mathrm{SB}$ & 34 & 34 \\
\hline $\begin{array}{l}\text { Projeto e medida do trabalho (estudo de tempos) + Aspectos de RH } \\
\text { em APO }\end{array}$ & $\begin{array}{c}1011 \\
13\end{array}$ & 7 & 10 & 995 & 15 & & $\begin{array}{c}9 \mathrm{~A} 2 \\
\mathrm{~A} 3\end{array}$ & 7 & 6 & 510 & 4832 & & 6 & 10 & & & 11 & 17 \\
\hline $\begin{array}{l}\text { Administração da demanda (estratégias de Marketing para mudar o } \\
\text { perfil da demanda) }\end{array}$ & 30 & 9 & & 13 & & & 11 & 12 & 10 & 16 & & & 10 & & & 12 & 13 & 9 \\
\hline Previsão & & 8 & 11 & 6 & 38 & 6 & \begin{tabular}{|c|c|}
11 & 14 \\
$\mathrm{~A} 1$ & \\
\end{tabular} & 3 & 10 & $77 \mathrm{~A}$ & 23 & \begin{tabular}{|ll}
11 & 12 \\
13 & 14 \\
\end{tabular} & 11 & SD & 2 & 12 & 8 & 8 \\
\hline Planejamento agregado e Plano mestre de produção & & 9 & 12 & 13 & 8 & 7 & 11 & 12 & 14 & 16 & 12 & 5153 & 12 & $\begin{array}{ll}11 & 12\end{array}$ & 3 & 14 & $\begin{array}{ll}13 & 14\end{array}$ & 9 \\
\hline MRP & 21 & 10 & 17 & 15 & 10 & 8 & 14 & 14 & 17 & 17 & $\begin{array}{c}511 \\
30\end{array}$ & 54 & 16 & 15 & 7 & 15 & 15 & 12 \\
\hline MRP II, ERP & 21 & 10 & & 15 & 10 & 8 & 14 & 14 & 17 & 17 & 1130 & 54 & 16 & 15 & 7 & 15 & 15 & 12 \\
\hline
\end{tabular}


Quadro 5: Conteúdos dos livros didáticos de APO (continuação)

\begin{tabular}{|c|c|c|c|c|c|c|c|c|c|c|c|c|c|c|c|c|c|c|}
\hline \multirow[b]{2}{*}{ Conteúdo de APO } & \multicolumn{8}{|c|}{ Livros nacionais e traduzidos } & \multicolumn{10}{|c|}{ Livros editados nos EUA } \\
\hline & 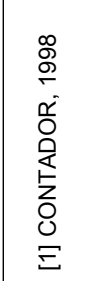 & 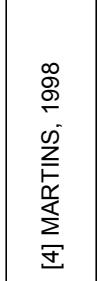 & 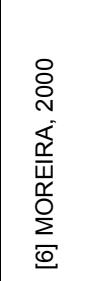 & 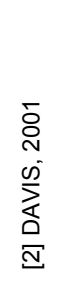 & 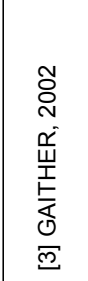 & 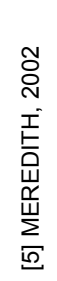 & 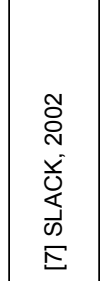 & 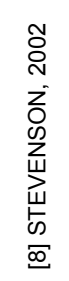 & 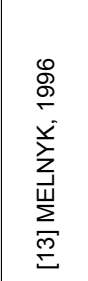 & 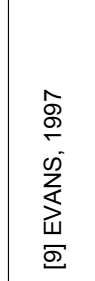 & 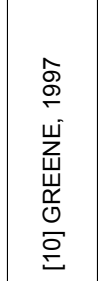 & 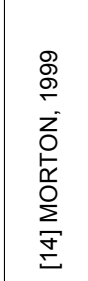 & 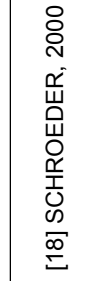 & 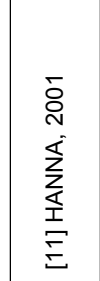 & 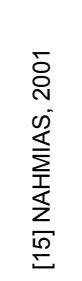 & 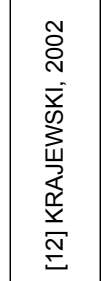 & 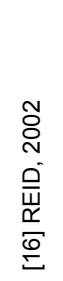 & 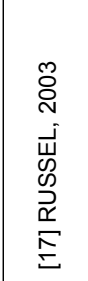 \\
\hline Planejamento, programação e controle da produção / operações & 19 & 11 & 13 & 16 & $\begin{array}{c}811 \\
12\end{array}$ & 7 & 10 & 17 & 18 & 18 & $\begin{array}{|ll|}13 & 14 \\
15 & 32 \\
\end{array}$ & $\begin{array}{ll}31 & 32 \\
33 & 34 \\
\end{array}$ & 13 & $\begin{array}{c}1314 \\
15\end{array}$ & 8 & SG 17 & 16 & 13 \\
\hline Administração de projetos: PERT e CPM & 20 & 12 & 14 & 10 & 18 & 10 & 16 & 18 & & 19 & 13 & $\begin{array}{ll}41 & 42 \\
43 & 44\end{array}$ & 14 & $16 S G$ & 9 & 4 & 17 & 6 \\
\hline Gestão de estoques & 18 & 4 & 1516 & 14 & 9 & 8 & 12 & 13 & 16 & 1314 & 1819 & \begin{tabular}{|ll}
21 & 22 \\
23 & 24
\end{tabular} & 15 & $\begin{array}{l}12 \\
\text { SE }\end{array}$ & 45 & $13 \mathrm{SE}$ & 12 & 10 \\
\hline Administração da cadeia de suprimentos & & 4 & & 11 & 14 & 9 & 13 & 16 & 13 & 13 & $\begin{array}{ll}20 & 22 \\
24 & 33\end{array}$ & & 10 & 212 & 6 & 11 & 4 & 775 \\
\hline Logística, movimentação e armazenagem de materiais & 2731 & 4 & & 11 & 14 & 9 & 13 & 16 & $\begin{array}{c}15 \\
19 \\
\end{array}$ & 13 & $\begin{array}{|ll|}18 & 20 \\
21 & 25 \\
\end{array}$ & 53 & 10 & 213 & 6 & & 4 & 7 \\
\hline Sistemas just-in-time & 1621 & 16 & & 12 & 13 & 9 & 15 & 15 & 9 & 15 & 16 & $\begin{array}{c}2431 \\
34\end{array}$ & 17 & 13 & 7 & 16 & 7 & 11 \\
\hline $\begin{array}{l}\begin{array}{l}\text { Teoria das restrições (TOC, gargalos, OPT - Optimized Production } \\
\text { Tecnology, manufatura síncrona) }\end{array} \\
\end{array}$ & & & & 16 & $\begin{array}{c}8 \\
11 \\
\end{array}$ & 6 & 6 & & 18 & 15 & 913 & 33 & 213 & 14 & 3 & 8 & 16 & 13 \\
\hline Qualidade: introdução, histórico, abordagens, gurus, conceitos. & 1416 & & & 5 & 16 & 3 & 1720 & 9 & 7 & 2 & 26 & 61 & 8 & 5 & & 6 & 5 & 14 \\
\hline Qualidade: CEP & 15 & 22 & 18 & $5 S$ & 1617 & 3 & 17 & 10 & 8 & 1112 & & 63 & 9 & 6 & 11 & $7 \mathrm{SJ}$ & 6 & $\begin{array}{c}15 \\
15 S\end{array}$ \\
\hline Qualidade: 5S, housekeeping & 16 & 17 & & & & & & & & & 16 & & & & & & & \\
\hline Qualidade: melhorias nos processos, PDCA, 7 ferramentas & $\begin{array}{c}3334 \\
35\end{array}$ & 1922 & & 5 & & 3 & 1819 & 11 & 48 & 11 & 2226 & 62 & 9 & 6 & & 6 & 5 & 14 \\
\hline Qualidade: TQM, ISO, Prêmios da Qualidade & 38 & 22 & & 5 & 16 & 3 & 20 & 11 & 7 & 2 & 26 & 62 & 8 & 5 & 11 & 6 & 5 & 1417 \\
\hline $\begin{array}{l}\text { Gestão da Manutenção (corretiva, preventiva, preditiva, TPM, controle } \\
\text { de ferramentas) }\end{array}$ & 1628 & 20 & & & & 9 & 19 & $17 S$ & $9 \mathrm{~A}$ & 11 & 714 & & & 3 & & 16 & & 11 \\
\hline Medida de produtividade & 9 & 21 & 19 & 4 & 15 & 2 & & 2 & 13 & 4 & 2 & & 10 & 1 & & $1 \mathrm{SI}$ & 2 & $\begin{array}{ll}1 & 14\end{array}$ \\
\hline Desafios e tendências na área de APO & 2339 & 20 & & 1 & & & 21 & 1 & 19 & & 32 & & 1 & & & 1 & 1 & 18 \\
\hline
\end{tabular}


Para aprofundar a comparação de conteúdo entre os livros, foi feita uma análise horizontal do quadro 5 para detectar a freqüência com que cada tópico foi tratado nos 18 livros sento obtida a figura 4, que permitiu a visualização de três grupos de tópicos:

- Tópicos principais (26): são tratados por mais de 13 livros e por isso representa o núcleo do conteúdo de APO do ponto de vista do livro didático.

- Introdução a APO (histórico, importância, conceitos, produto X serviço)

- Competitividade e estratégia de produção

○ Engenharia econômica (ponto de equilíbrio, VPL, Depreciação...)

- Planejamento e controle da capacidade

○ Localização

- Projeto do produto / serviço

- Projeto do processo (seleção, desenvolvimento)

- Arranjo físico (layout)

- Tecnologia (informação, produção, processo, CAD, CAM, CIM...)

- Projeto e medida do trabalho (estudo de tempos) + Aspectos de RH em APO

○ Previsão

- Planejamento agregado e Plano mestre de produção

O MRP

○ MRP II, ERP

- Planejamento, programação e controle da produção / operações

- Administração de projetos: PERT e CPM

- Gestão de estoques

- Administração da cadeia de suprimentos

- Logística, movimentação e armazenagem de materiais

- Sistemas just-in-time

○ Teoria das restrições (TOC, gargalos, OPT - Optimized Production Tecnology, manufatura síncrona)

○ Qualidade: introdução, histórico, abordagens, gurus, conceitos.

- Qualidade: CEP

- Qualidade: melhorias nos processos, PDCA, 7 ferramentas

- Qualidade: TQM, ISO, Prêmios da Qualidade

- Medida de produtividade 


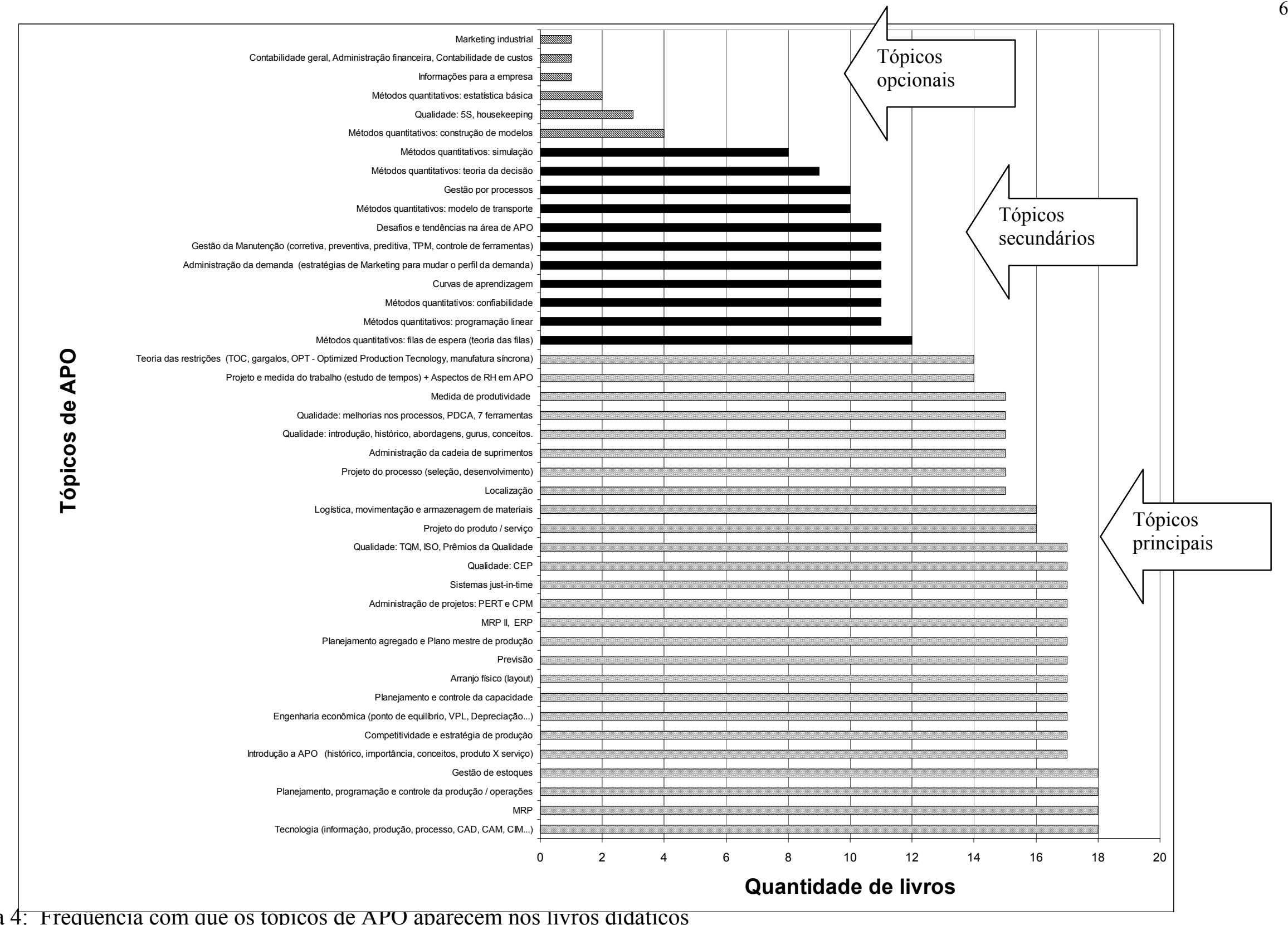

Figura 4: Frequencia com que os topicos de APU aparecem nos livros didaticos 
- Tópicos secundários (11): são tratados por metade dos livros analisados (8 a 12 em 18) e representa o conteúdo de APO que varia conforme a ênfase de cada autor:

- Métodos quantitativos: programação linear

- Métodos quantitativos: modelo de transporte

- Métodos quantitativos: teoria da decisão

- Métodos quantitativos: filas de espera (teoria das filas)

- Métodos quantitativos: simulação

- Métodos quantitativos: confiabilidade

- Curvas de aprendizagem

- Gestão por processos

- Administração da demanda (estratégias de Marketing para mudar o perfil da demanda)

○ Gestão da Manutenção (corretiva, preventiva, preditiva, TPM, controle de ferramentas)

- Desafios e tendências na área de APO

- Tópicos opcionais (6): são tratados pela minoria dos livros analisados (4 ou menos em 18) e apesar de terem relação com APO, podendo até ser um pré-requisito, como é o caso de Estatística básica, talvez não mereçam um capítulo nos livros didáticos de APO:

○ Informações para a empresa

- Métodos quantitativos: construção de modelos

- Métodos quantitativos: estatística básica

- Contabilidade geral, Administração financeira, Contabilidade de custos

- Marketing industrial

- Qualidade: 5S, housekeeping

Finalizando a comparação de conteúdo entre os livros, foi feita uma análise vertical do quadro 5 para identificar o número de "lacunas de conteúdo", isto é, a quantidade de tópicos principais ou secundários que não foram tratados pelos autores, e em separado a quantidade de tópicos opcionais. Desta análise foi preparado o quadro 6, que é comentado a seguir:

- Dos dez livros mais completos, cinco deles já estão disponíveis em língua portuguesa.

- Os livros de autores brasileiros estão entre os menos completos, com destaque para o livro de coordenação do professor José Celso Contador, que apesar de possuir 39 capítulos, sendo quatro capítulos de tópicos opcionais, não foi dedicado nenhum capítulo a 14 tópicos considerados principais ou secundários. 
Quadro 6: Abrangência de conteúdo dos livros didáticos analisados

\begin{tabular}{|c|l|c|c|}
\hline \multicolumn{2}{|c|}{ Autores } & $\begin{array}{c}\text { Lacunas de } \\
\text { conteúdo }\end{array}$ & $\begin{array}{c}\text { Tópicos } \\
\text { opcionais }\end{array}$ \\
\hline $1^{\circ}$ & {$[17]$ RUSSEL; TAYLOR III, 2003 } & 0 & 0 \\
\hline $2^{\circ}$ & {$[8]$ STEVENSON, 2002 } & 2 & 0 \\
\hline $3^{\circ}$ & {$[9]$ EVANS, 1997 } & 2 & 1 \\
\hline $4^{\circ}$ & {$[16]$ REID; SANDERS, 2002 } & 3 & 0 \\
\hline $5^{\circ}$ & {$[12]$ KRAJEWSKI; RITZMAN, 2002 } & 4 & 0 \\
\hline $6^{\circ}$ & {$[10]$ GREENE, 1997 } & 4 & 3 \\
\hline $7^{\circ}$ & {$[11]$ HANNA; NEWMAN, 2001 } & 5 & 0 \\
\hline $8^{\circ}$ & {$[2]$ DAVIS; AQUILANO; CHASE, 2001 } & 6 & 0 \\
\hline $9^{\circ}$ & {$[7]$ SLACK; CHAMBERS; JOHNSTON, 2002 } & 6 & 0 \\
\hline $10^{\circ}$ & {$[5]$ MEREDITH; SHAFER, 2002 } & 7 & 0 \\
\hline $11^{\circ}$ & {$[13]$ MELNYK; DENZLER, 1996 } & 7 & 1 \\
\hline $12^{\circ}$ & {$[3]$ GAITHER; FRAZIER, 2002 } & 8 & 0 \\
\hline $13^{\circ}$ & {$[4]$ MARTINS; LAUGENI, 1998 } & 8 & 1 \\
\hline $14^{\circ}$ & {$[15]$ NAHMIAS, 2001 } & 10 & 0 \\
\hline $15^{\circ}$ & {$[18]$ SCHROEDER, 2000 } & 10 & 0 \\
\hline $16^{\circ}$ & {$[6]$ MOREIRA, 2000 } & 14 & 2 \\
\hline $17^{\circ}$ & {$[1]$ CONTADOR, 1998 } & 14 & 4 \\
\hline $18^{\circ}$ & {$[14]$ MORTON, 1999 } & 15 & 0 \\
\hline
\end{tabular}

Do ponto de vista da estrutura dos livros e seus recursos de aprendizagem, a comparação resultou no quadro 7 , do qual se fazem os seguintes comentários:

- As principais características utilizadas em pelo menos 14 dos 18 livros são:

- Resumo de cada capítulo destacando os pontos-chave

○ Índice (tópicos em ordem alfabética)

- Estudos de caso (vinhetas, exemplos ou exercícios), porém não há casos brasileiros

○ Exercícios ao final de cada capítulo

- Os livros americanos, com exceção do livro editado por James H. Greene (1997), possuem algum recurso adicional, seja CD-ROM, site do livro ou pacote suplementar. Para os livros nacionais ou traduzidos esses recursos ainda são a exceção.

- Na média, os três livros de autores brasileiros possuem 552 páginas, enquanto os outros, 732. Para eliminar essa diferença de 180 páginas, os livros brasileiros teriam que ser $33 \%$ maiores.

- A classificação dos livros em ordem cronológica no quadro 7 permitiu visualizar que nos últimos anos (a partir de 2001 para os livros traduzidos e 2000 para os livros americanos) têm sido disponibilizados mais recursos de aprendizagem. 
Quadro 7: Estrutura e recursos de aprendizagem dos livros didáticos de APO

\begin{tabular}{|c|c|c|c|c|c|c|c|c|c|c|c|c|c|c|c|c|c|c|}
\hline \multirow[b]{2}{*}{ Estrutura e recursos de aprendizagem } & \multicolumn{8}{|c|}{ Livros nacionais e traduzidos } & \multicolumn{10}{|c|}{ Livros editados nos EUA } \\
\hline & 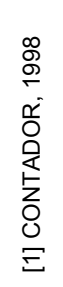 & 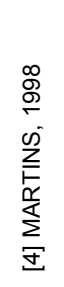 & 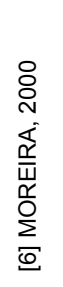 & $\begin{array}{l}\bar{\vdots} \\
\stackrel{N}{ } \\
\text { w } \\
⿱ 亠 乂 \\
\Delta \\
\underline{a}\end{array}$ & 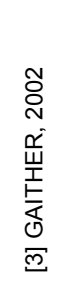 & 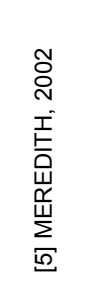 & 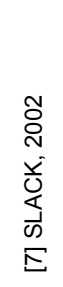 & 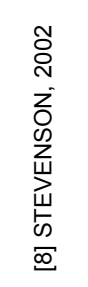 & 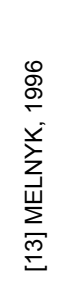 & 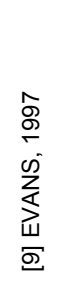 & 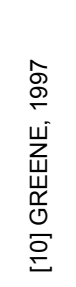 & 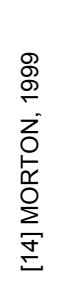 & 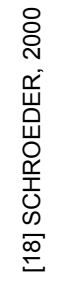 & 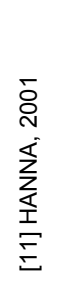 & 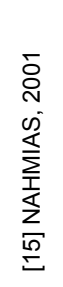 & 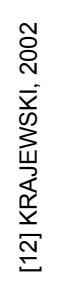 & 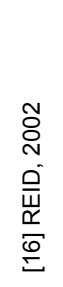 & 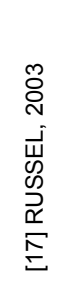 \\
\hline Objetivos de aprendizagem no início de cada capítulo & & & & $\operatorname{sim}$ & & & $\operatorname{sim}$ & $\operatorname{sim}$ & $\operatorname{sim}$ & & & & & $\operatorname{sim}$ & & $\operatorname{sim}$ & $\operatorname{sim}$ & \\
\hline Resumo de cada capítulo destacando os pontos-chave & & & $\operatorname{sim}$ & & & $\operatorname{sim}$ & $\operatorname{sim}$ & $\operatorname{sim}$ & $\operatorname{sim}$ & $\operatorname{sim}$ & $\operatorname{sim}$ & $\operatorname{sim}$ & $\operatorname{sim}$ & $\operatorname{sim}$ & $\operatorname{sim}$ & $\operatorname{sim}$ & $\operatorname{sim}$ & $\operatorname{sim}$ \\
\hline Referências ao (final de cada capitulo $=$ CA) (final do livro $=$ LI) & CA & LI & CA & CA & & CA & CA & CA & CA & CA & CA & CA & CA & CA & CA & CA & CA & CA \\
\hline $\begin{array}{l}\text { Quadros ou Ícones indicando a conexão do capítulo com outras área } \\
\text { funcionais }\end{array}$ & & & & $\operatorname{sim}$ & & & & & & & & & $\operatorname{sim}$ & $\operatorname{sim}$ & & $\operatorname{sim}$ & $\operatorname{sim}$ & \\
\hline Índice (tópicos em ordem alfabética) & & $\operatorname{sim}$ & & $\operatorname{sim}$ & $\operatorname{sim}$ & $\operatorname{sim}$ & $\operatorname{sim}$ & $\operatorname{sim}$ & $\operatorname{sim}$ & $\operatorname{sim}$ & $\operatorname{sim}$ & & $\operatorname{sim}$ & $\operatorname{sim}$ & $\operatorname{sim}$ & $\operatorname{sim}$ & $\operatorname{sim}$ & $\operatorname{sim}$ \\
\hline Estudos de casos (vinhetas, exemplos ou exercícios) & & & & $\operatorname{sim}$ & $\operatorname{sim}$ & $\operatorname{sim}$ & $\operatorname{sim}$ & $\operatorname{sim}$ & $\operatorname{sim}$ & $\operatorname{sim}$ & & $\operatorname{sim}$ & $\operatorname{sim}$ & $\operatorname{sim}$ & $\operatorname{sim}$ & $\operatorname{sim}$ & $\operatorname{sim}$ & $\operatorname{sim}$ \\
\hline Exercícios ao final de cada capítulo & $\operatorname{sim}$ & $\operatorname{sim}$ & $\operatorname{sim}$ & $\operatorname{sim}$ & $\operatorname{sim}$ & $\operatorname{sim}$ & $\operatorname{sim}$ & $\operatorname{sim}$ & $\operatorname{sim}$ & $\operatorname{sim}$ & & $\operatorname{sim}$ & $\operatorname{sim}$ & $\operatorname{sim}$ & $\operatorname{sim}$ & $\operatorname{sim}$ & $\operatorname{sim}$ & sim \\
\hline Respostas de exercícios selecionados no final do livro & & & & $\operatorname{sim}$ & $\operatorname{sim}$ & & $\operatorname{sim}$ & $\operatorname{sim}$ & & $\operatorname{sim}$ & & & & & & & $\operatorname{sim}$ & $\operatorname{sim}$ \\
\hline CD-ROM com recursos adicionais (incluso) & & & & $\operatorname{sim}$ & & & & $\operatorname{sim}$ & & & & & $\operatorname{sim}$ & $\operatorname{sim}$ & $\operatorname{sim}$ & $\operatorname{sim}$ & $\operatorname{sim}$ & $\operatorname{sim}$ \\
\hline $\begin{array}{l}\text { Site do livro com exercíicios, apresentações PowerPoint, video clips, } \\
\text { links das empresas citadas, artigos, softwares. }\end{array}$ & & & & & Prof & Inglês & & Inglês & & & & & $\operatorname{sim}$ & $\operatorname{sim}$ & $\operatorname{sim}$ & $\operatorname{sim}$ & sim & $\operatorname{sim}$ \\
\hline $\begin{array}{l}\text { Pacote suplementar (Materiais de apoio vendidos separadamente: } \\
\text { video, apresentações PowerPoint, manuais, testes, softwares) }\end{array}$ & & & & & & & & & $\operatorname{sim}$ & $\operatorname{sim}$ & & $\operatorname{sim}$ & sim & $\operatorname{sim}$ & & $\operatorname{sim}$ & $\operatorname{sim}$ & $\operatorname{sim}$ \\
\hline Número de páginas & 593 & 445 & 619 & 598 & 598 & 391 & 754 & 701 & 988 & 934 & 1178 & 538 & 396 & 777 & 810 & 883 & 614 & 824 \\
\hline
\end{tabular}


CAPÍTULO 5

O conteúdo de APO do ponto

de vista do Provão 


\section{O conteúdo de APO do ponto de vista do Provão}

Uma importante fonte de influência e mudança nos programas e nas práticas do ensino de APO é representada por mecanismos avaliadores, mantidos por organizações de origem governamental ou não. A influência pode ser direta (sugestões sobre o próprio conteúdo do currículo de APO ou estratégias de seu ensino) como indireta, ou seja, incidir sobre o ensino de APO através do currículo de um curso completo ao qual APO pertença (MOREIRA, 1999, p. 91).

A certificação de cursos é uma prática comum nos EUA e na Europa, e no Brasil já tem sido considerada uma necessidade. O que fica evidenciado nos exemplos a seguir:

Há um consenso hoje de que a internacionalização e a certificação em entidades reconhecidas são fundamentais para o futuro de escolas como a nossa. [...] Ela nos oferece reconhecimento internacional, reforça nosso compromisso com a qualidade e promove um aperfeiçoamento contínuo (FEA-USP on line, 2004).

Em dezembro de 2001, a FGV-EAESP conquistou mais um importante credenciamento internacional: o EQUIS (European Quality Improvement System), um sistema criado em 1997 pela European Foundation for Management Development (EFMD), sediada em Bruxelas (Bélgica). Esse selo de qualidade soma-se ao da AACSB, obtido em abril de 2000.

A EAESP, a primeira escola da América Latina a possuir estes dois importantes credenciamentos, faz parte de um seleto grupo de apenas onze instituições, no mundo, que possuem os selos de qualidade acadêmica AACSB e EQUIS. O EQUIS avalia o desempenho das instituições acadêmicas com base em critérios internacionais, em um processo no qual as escolas são apreciadas por seus pares e clientes. Assim, obter o selo EQUIS da EFMD significa ter um reconhecimento de qualidade internacional, além de trazer, também, a garantia de um acompanhamento de auditoria estratégica que servirá como guia para o contínuo desenvolvimento da Escola. (FGV-SP on line, 2004).

A AACSB é uma associação sem fins lucrativos, criada em 1916 por algumas das mais importantes escolas de negócio americanas como American Assembly of Collegiate Schools of Business, sendo designada atualmente como The Association to Advance Collegiate School of Business. A excelência no ensino da Administração de Empresas é estimulada através da certificação de cursos e incentivo a intercâmbios internacionais, contatos na área de negócios, discussão das melhores práticas, desenvolvimento profissional e outros serviços (AACSB on line, 2004a).

As normas da AACSB fornecem diretrizes para a IES executarem seu planejamento estratégico (para 5 anos com revisões anuais), considerando os seguintes desafios: 
- Forças econômicas globais crescentes.

- Diferenças nos valores organizacionais e culturais.

- Diversidade cultural entre os empregados e clientes.

- Mudança tecnológica em produtos e processos.

Quanto ao conteúdo dos cursos, a orientação da AACSB é genérica (currículo deve ser consistente com a missão institucional e a disponibilidade de recursos) e em particular para a área de APO pode-se destacar o tópico: "Criação de valor através da produção e distribuição integradas de bens, serviços e informação”.

De modo similar, no EQUIS (European Quality Improvement System) as IES's têm que demonstrar não somente um alto grau de qualidade em todas as dimensões de suas atividades, mas também um alto grau de internacionalização. Para a presente pesquisa é importante destacar que o EQUIS não define o currículo do curso (nem as disciplinas, nem os conteúdos), mas especifica que deve haver um processo para avaliação do curso que garanta que as necessidades do mercado e dos participantes têm sido atendidas.

No Brasil não há um sistema para certificação dos cursos como o da AACSB ou o EQUIS, mas o Instituto Nacional de Estudos e Pesquisas Educacionais (INEP) tem sido o órgão responsável pelo Sistema de Avaliação da Educação Superior, que é composto pela Avaliação Institucional (AI), Avaliação das Condições de Ensino (ACE), Exame Nacional de Cursos (ENC - Provão), Cadastro da Educação Superior e o Censo da Educação Superior. O Provão iniciou-se em 1996 com os cursos de Administração de Empresas, Direito e Engenharia Civil e a cada ano novos cursos têm sido incorporados.

Para a elaboração das questões do Provão, uma comissão toma por base os conteúdos definidos nas diretrizes que são publicadas anualmente e para o curso de Administração de Empresas esses conteúdos têm sido divididos em:

- Matérias de formação básica e instrumental: Contabilidade; Direito; Economia; Estatística; Matemática; Informática; Filosofia; Psicologia e Sociologia;

- Matérias de formação profissional: Teorias da Administração; Administração Mercadológica; Administração de Recursos Humanos; Administração Financeira e Orçamentária; Administração de Sistemas de Informação; Administração de Produção; 
Administração de Recursos Materiais e Patrimoniais e Organização, Sistemas e Métodos;

- Tópicos emergentes: Ética e responsabilidade social e Ecologia e Meio Ambiente, foram tópicos definidos para os ENC's de 2002 e 2003. Os exames anteriores incluíram outros tópicos como: Globalização e a Nova Economia, Qualidade e Tecnologia da Informação.

Em 2002 a Associação Nacional dos Cursos de Graduação em Administração (ANGRAD), o Conselho Federal de Administração (CFA) e a Ad Homines realizaram uma pesquisa junto a 202 coordenadores de cursos de graduação em Administração (40,6\% dos cursos que participaram do Provão 2001) e identificaram que $64,4 \%$ dos cursos pesquisados passaram por alterações nos últimos três anos, e em 35,8\% dos cursos houve alterações influenciadas pelo Provão (ANGRAD; CFA; AD HOMINES on line, 2003). Dentre os 56 aspectos avaliados como "alterações influenciadas pelo Provão", os mais citados foram:

$1^{\circ}$ Uso das questões do provão em aula

$2^{\circ}$ Didática do curso

$3^{\circ}$ Conteúdo do curso

$4^{\circ}$ Revisão para o Provão (menos citada nas IES com conceitos A ou B - $21^{\circ} \mathrm{em}$ ordem de importância)

$5^{\circ}$ Interdisciplinaridade (menos citado nas IES com conceitos A ou B $-22^{\circ}$ em ordem de importância)

$6^{\circ}$ Elaboração de simulados para o Provão (menos citado nas IES com conceitos A ou B $23^{\circ}$ em ordem de importância)

$7^{\circ}$ Acervo da biblioteca

$8^{\circ}$ Qualificação do corpo docente

$9^{\circ}$ Melhoria da imagem da IES

$10^{\circ}$ Seqüência das disciplinas (aspecto menos citado nas IES com conceitos $\mathrm{A}$ ou $\mathrm{B}-31^{\circ}$ em ordem de importância)

$11^{\circ}$ Dedicação dos alunos ao curso

Há certo consenso entre os respondentes (independente do conceito) nos três aspectos mais citados, que correspondem especificamente ao Curso de Administração, ou 
seja, o Provão influenciou o conteúdo dos cursos e tem sido usado como um recurso didático. Essa constatação justifica um dos objetivos desta pesquisa: analisar os conteúdos de APO do ponto de vista do Provão, o que será feito a seguir, comparando as quantidades de questões que envolvem as várias disciplinas de formação profissional e identificando os conteúdos de APO dos Provões de 2001 a 2003.

Nos últimos três anos a Administração da Produção tem ocupado a $5^{\mathrm{a}}$ posição entre as oito matérias de formação profissional (tabela 4), o que pode ser considerado como adequado, dado que a quantidade de questões de APO está na média esperada (40 questões / 8 matérias).

Tabela 4: Evolução da quantidade de questões do Provão de Administração por matéria

\begin{tabular}{l|c|c|c|c|c|c|c}
\hline \multirow{2}{*}{$\begin{array}{c}\text { Matérias de formação } \\
\text { profissional }\end{array}$} & \multicolumn{2}{|c|}{2001} & \multicolumn{2}{c|}{2002} & \multicolumn{2}{c}{2003} & \multirow{2}{*}{ TOTAL } \\
\cline { 2 - 7 } & $\begin{array}{c}\text { Prova } \\
\text { discursiva } \\
(2)\end{array}$ & $\begin{array}{c}\text { Prova } \\
\text { objetiva } \\
(40)\end{array}$ & $\begin{array}{c}\text { Prova } \\
\text { discursiva } \\
(2)\end{array}$ & $\begin{array}{c}\text { Prova } \\
\text { objetiva } \\
(40)\end{array}$ & $\begin{array}{c}\text { Prova } \\
\text { discursiva } \\
(2)\end{array}$ & $\begin{array}{c}\text { Prova } \\
\text { objetiva } \\
(40)\end{array}$ & \\
\hline Teorias da Administração & 1 & 8 & 2 & 14 & 1 & 10 & 36 \\
\hline Administração Mercadológica & 1 & 6 & 1 & 7 & 1 & 7 & 23 \\
\hline Administração de RH & 1 & 6 & 1 & 8 & 1 & 7 & 24 \\
\hline $\begin{array}{l}\text { Administração Financeira e } \\
\text { Orçamentária }\end{array}$ & 1 & 6 & 1 & 6 & 1 & 6 & 21 \\
\hline $\begin{array}{l}\text { Administração de Sistemas de } \\
\text { Informação }\end{array}$ & 1 & 4 & 1 & 4 & 1 & 4 & 15 \\
\hline Administração da Produção & 1 & 4 & 1 & 5 & 1 & 6 & 18 \\
\hline $\begin{array}{l}\text { Adm. de Recursos Materiais e } \\
\text { Patrimoniais }\end{array}$ & 1 & 5 & 0 & 3 & 1 & 3 & 13 \\
\hline $\begin{array}{l}\text { Organização, sistemas e } \\
\text { métodos }\end{array}$ & 0 & 4 & 1 & 3 & 0 & 3 & 11 \\
\hline
\end{tabular}

Fonte: INEP (on line, 2004b) 
O quadro 8 resultou da análise de conteúdo das questões do Provão, que foi feita com base na classificação do próprio INEP, isto é, através de documentos emitidos pelo INEP que relacionavam as matérias envolvidas em cada questão ( $3^{a}$ coluna do quadro 8$)$, foram destacadas as questões de Administração da Produção ou de Administração de Recursos Materiais e Patrimoniais e assim procedeu-se a uma análise detalhada dos conteúdos específicos destas questões.

A primeira observação a ser feita é que praticamente todas as questões exigem o conhecimento de conteúdos de mais de uma disciplina, porém algumas questões (34 de 2001; 25, 27, 28 e 30 de 2002 e 28, 32 e 33 de 2003) envolvem conceitos de APO, mas a sua resolução depende mais de um raciocínio lógico-quantitativo, que talvez seja abordado mais profundamente em outras disciplinas como matemática, economia, estatística ou contabilidade, as quais podem ser tratadas como pré-requisitos para APO.

O número de questões objetivas envolvendo conteúdos de APO tem aumentado de 7 em 2001 para 8 em 2002 e 9 em 2003, porém, se as questões fossem distribuídas uniformemente entre as oito matérias, esse total poderia ter chegado a 10 (5 de Administração da Produção e 5 de Administração de Recursos Materiais e Patrimoniais). 
Quadro 8: Conteúdos de APO no ENC de 2001 a 2003

\begin{tabular}{|c|c|c|c|}
\hline ANO & Questão & Conteúdos (matérias) & Conteúdos de APO \\
\hline \multirow{8}{*}{2001} & 28 & Administração de Produção & MRP: estrutura de produto \\
\hline & 29 & $\begin{array}{l}\text { Administração de Produção e de Recursos Materiais e } \\
\text { Patrimoniais }\end{array}$ & Planejamento Agregado: nivelamento da produção \\
\hline & 30 & Administração de Produção & $\begin{array}{l}\text { Planejamento e Controle da Capacidade: capacidade de projeto e } \\
\text { capacidade efetiva, utilização e eficiência. }\end{array}$ \\
\hline & 31 & Administração de Recursos Materiais e Patrimoniais & $\begin{array}{l}\text { Planejamento e Controle de Estoques: estoque médio anual, giro de } \\
\text { estoque. }\end{array}$ \\
\hline & 32 & Administração de Recursos Materiais e Patrimoniais & Previsão: média móvel simples \\
\hline & 33 & $\begin{array}{l}\text { Administração de Produção e de Recursos Materiais e } \\
\text { Patrimoniais }\end{array}$ & $\begin{array}{l}\text { Planejamento e Controle da Capacidade: demanda, estoques, sistemas de } \\
\text { produção. }\end{array}$ \\
\hline & 34 & Administração de Recursos Materiais e Patrimoniais & $\begin{array}{l}\text { Cita conceitos da Programação e Controle da Produção: PEPS e UEPS, } \\
\text { mas o problema está na Contabilidade dos custos de estoque. }\end{array}$ \\
\hline & 1 Discursiva & $\begin{array}{l}\text { Administração Financeira e Orçamentária, Administração de } \\
\text { produção, Administração de Recursos Materiais e } \\
\text { Patrimoniais, Administração de Sistemas de Informação, } \\
\text { Contabilidade. }\end{array}$ & $\begin{array}{l}\text { Redução de custo através do aumento da produtividade, redução de } \\
\text { desperdícios e redução de estoques }\end{array}$ \\
\hline
\end{tabular}


Quadro 8: Conteúdos de APO no ENC de 2001 a 2003 (continuação)

\begin{tabular}{|c|c|c|c|}
\hline ANO & Questão & Conteúdos (matérias) & Conteúdos de APO \\
\hline \multirow{9}{*}{2002} & 14 & $\begin{array}{l}\text { Administração de RH, Administração de Produção e Teorias } \\
\text { da Administração }\end{array}$ & $\begin{array}{l}\text { Gestão da qualidade: não-conformidade, levantamento de causas, ação } \\
\text { corretiva, levantamento de necessidades de treinamento. }\end{array}$ \\
\hline & 24 & $\begin{array}{l}\text { Administração de Recursos Materiais e Patrimoniais, } \\
\text { Contabilidade, Estatística e Matemática }\end{array}$ & Controle de estoques: curva $\mathrm{ABC}$. \\
\hline & 25 & $\begin{array}{l}\text { Administração de Recursos Materiais e Patrimoniais, } \\
\text { Contabilidade e Matemática }\end{array}$ & $\begin{array}{l}\text { Cita conceitos da Programação e Controle da Produção: PEPS, mas o } \\
\text { problema está na Contabilidade dos custos de estoque. }\end{array}$ \\
\hline & 26 & $\begin{array}{l}\text { Administração de Recursos Materiais e Patrimoniais, } \\
\text { Contabilidade, Estatística e Matemática }\end{array}$ & $\begin{array}{l}\text { Controle de estoques: gráfico Dente de Serra, custo de estoque, risco de } \\
\text { falta. }\end{array}$ \\
\hline & 27 & $\begin{array}{l}\text { Administração da Produção, Contabilidade, Economia e } \\
\text { Matemática }\end{array}$ & Ponto de equilíbrio (Matemática e Economia) \\
\hline & 28 & Administração da Produção, Economia e Matemática & Confiabilidade (Estatística: probabilidade) \\
\hline & 29 & Administração da Produção, Economia e Matemática & Previsão da demanda: média móvel simples \\
\hline & 30 & Administração da Produção e Matemática & $\begin{array}{l}\text { Compara pequeno processo manual, médio processo semi-automático e } \\
\text { grande processo automático (custo unitário X volume de produção), mas o } \\
\text { problema está na interpretação de gráficos (Matemática). }\end{array}$ \\
\hline & 1 Discursiva & $\begin{array}{l}\text { Teorias da Administração, Administração Mercadológica, } \\
\text { Administração de RH, Administração de Produção, Ética, } \\
\text { Ecologia e Meio Ambiente }\end{array}$ & $\begin{array}{l}\text { Localização de instalações: mercado, matéria-prima, incentivos fiscais, infra- } \\
\text { estrutura, mão de obra,... }\end{array}$ \\
\hline
\end{tabular}


Quadro 8: Conteúdos de APO no ENC de 2001 a 2003 (continuação)

\begin{tabular}{|c|c|c|c|}
\hline ANO & Questão & Conteúdos (matérias) & Conteúdos de APO \\
\hline \multirow{10}{*}{2003} & 22 & $\begin{array}{l}\text { Administração Financeira e Orçamentária, Administração de } \\
\text { produção e Matemática }\end{array}$ & Lote econômico de fabricação: custos de preparação $x$ custos de estoque \\
\hline & 27 & Administração de produção, Estátística e Matemática & Planejamento Agregado: nivelamento da produção \\
\hline & 28 & $\begin{array}{l}\text { Administração de produção, Economia, Estátística e } \\
\text { Matemática }\end{array}$ & $\begin{array}{l}\text { Cita Células de Produção e Linha de Montagem Automatizada, mas o } \\
\text { problema está na interpretação de gráficos (Matemática e Economia - } \\
\text { ponto de equilíbrio) }\end{array}$ \\
\hline & 29 & Administração de produção e Matemática & MRP: estrutura de produto, controle de estoques, demanda dependente \\
\hline & 30 & Administração de produção e Matemática & Administração de projetos: diagrama de rede, PERT, CPM, Caminho crítico \\
\hline & 31 & $\begin{array}{l}\text { Administração de produção, Organização, Sistemas e } \\
\text { Métodos, Estátística e Matemática }\end{array}$ & Medida da produtividade \\
\hline & 32 & $\begin{array}{l}\text { Administração de Recursos Materiais e Patrimoniais, } \\
\text { Estatística e Matemática }\end{array}$ & $\begin{array}{l}\text { Cita custos de transporte, mas o problema está na interpretação da tabela } \\
\text { de custos (Matemática) }\end{array}$ \\
\hline & 33 & $\begin{array}{l}\text { Administração de Recursos Materiais e Patrimoniais, } \\
\text { Contabilidade e Matemática }\end{array}$ & $\begin{array}{l}\text { Cita conceitos da Programação e Controle da Produção: PEPS, UEPS, mas } \\
\text { o problema está na Contabilidade dos custos de estoque. }\end{array}$ \\
\hline & 34 & $\begin{array}{l}\text { Administração de Recursos Materiais e Patrimoniais, } \\
\text { Contabilidade, Estatística e Matemática }\end{array}$ & Controle de estoques: estoque de segurança e ponto de pedido. \\
\hline & 1 Discursiva & $\begin{array}{l}\text { Administração financeira e Orçamentária, Administração de } \\
\text { Sistemas de Informação, Administração de Produção, } \\
\text { Administração de recursos Materiais e Patrimoniais, Ética e } \\
\text { Responsabilidade Social, Contabilidade, Economia, } \\
\text { Matemática, Informática e Filosofia. }\end{array}$ & $\begin{array}{l}\text { Produtividade e competitividade: redução de desperdício, redução de } \\
\text { devoluçães, redução de custos de fabricação, redução de estoques, } \\
\text { atualização tecnológica dos equipamentos (redução dos custos de } \\
\text { manutenção) e integração dos processos produtivos. }\end{array}$ \\
\hline
\end{tabular}

Fonte: INEP (on line, 2004b). 
Finalmente, a partir do quadro 8 foi preparada a lista abaixo com os conteúdos que foram exigidos nos últimos três anos, o que permite avaliar não só a abrangência, mas também os tópicos que têm sido mais constantes nos exames, o que parece indicar sua importância do ponto de vista das comissões que têm elaborado as provas.

\section{Planejamento da capacidade:}

- Demanda, estoques, sistemas de produção.

- Capacidade de projeto e capacidade efetiva, utilização e eficiência.

- Cita Células de Produção e Linha de Montagem Automatizada, mas o problema está na interpretação de gráficos (Matemática e Economia - ponto de equilíbrio)

- Ponto de equilíbrio (Matemática e Economia)

- Compara pequeno processo manual, médio processo semi-automático e grande processo automático (custo unitário versus volume de produção), mas o problema está na interpretação de gráficos (Matemática).

\section{Localização das instalações:}

- Mercado, matéria-prima, incentivos fiscais, infra-estrutura, mão de obra,...

- Cita custos de transporte, mas o problema está na interpretação da tabela de custos (Matemática)

\section{Projeto do produto:}

- Confiabilidade (Estatística: probabilidade)

Previsão da demanda:

- Média móvel simples (2 questões)

\section{Planejamento agregado:}

- Nivelamento da produção (2 questões)

\section{MRP:}

- MRP: estrutura de produto, controle de estoques, demanda dependente (2 questões)

\section{Administração de projetos:}

- Diagrama de rede, PERT, CPM.

\section{Planejamento e controle de estoques:}

- Curva ABC.

- PEPS, UEPS e Contabilidade dos custos de estoque (3 questões).

- Gráfico Dente de Serra, custo de estoque, risco de falta.

- Estoque de segurança e ponto de pedido.

- Estoque médio anual, giro de estoque.

- Lote econômico de fabricação: custos de preparação x custos de estoque

\section{Produtividade:}

- Medida da produtividade

- Produtividade e competitividade: redução de desperdício, redução de devoluções, redução de custos de fabricação, redução de estoques, atualização tecnológica dos 
equipamentos (redução dos custos de manutenção) e integração dos processos produtivos. (2 questões)

\section{Prevenção e recuperação de falhas:}

- Gestão da qualidade: não-conformidade, levantamento de causas, ação corretiva, levantamento de necessidades de treinamento.

Pelo que foi exposto nessa seção pode-se extrair algumas conclusões:

- o Provão influenciou o conteúdo dos cursos e tem sido usado como um recurso didático (ANGRAD; CFA; AD HOMINES on line, 2003);

- apesar da dificuldade de se abranger todo o conteúdo de APO, pode-se afirmar que o Provão tem exigido os conceitos básicos de forma coerente com os conteúdos disponibilizados nos livros didáticos, isto é, todo o conteúdo do Provão está entre os tópicos que classificamos como principais na análise dos livros didáticos;

- a interdisciplinaridade de APO com as outras matérias de formação profissional do curso de Administração é mais pronunciada nas questões discursivas.

- Em 1999, Moreira tinha feito uma análise das provas de 1996 a 1999 e não pôde concluir quanto aos conteúdos particulares de APO, mas para as provas de 2001 a 2003 já foi possível obter uma lista de tópicos e até compará-la com os resultados que já tinham sido obtidos na análise dos livros didáticos. Essa diferença talvez seja conseqüência de melhorias no processo de elaboração das questões. 
CAPÍTULO 6

O ensino de APO nas escolas pesquisadas 


\section{Onsino de APO nas escolas pesquisadas}

No capítulo 3 foram comentados os motivos da escolha dos cursos da FEA-PUCSP, da FEA-USP e da FGV-EAESP e neste capítulo serão evidenciadas as características atuais de cada curso, apontando suas diferenças e semelhanças. Apesar de o contexto histórico ter certa influência nessas características, não é objetivo desta tese discutir essa questão, ou seja, serão apresentadas "quais" as características dos cursos sem comentar os "porquês" ou "como" estas características se desenvolveram.

A FEA-PUC-SP tem oferecido um curso de Administração de Empresas com duração de dez semestres e a cada ano 600 alunos preenchem as seis turmas da manhã e seis da noite, com uma concorrência de 2,74 candidatos por vaga. Enquanto na FEA-USP a procura, neste ano, foi de 29,46 candidatos por vaga para as 100 vagas do período diurno e 110 do período noturno, cuja duração é de oito semestres no período diurno e dez no período noturno. Desta forma, passamos a uma breve apresentação.

O Curso de Graduação em Administração de Empresas (CGAE) da FGV-EAESP é oferecido no período diurno, com aulas de manhã e à tarde, nos quatro primeiros semestres. Nos quatro semestres seguintes, as aulas são ministradas na parte da manhã ou da tarde, para permitir ao aluno a realização de estágios. O processo seletivo é realizado semestralmente, oferecendo 150 vagas, dessa forma as turmas em cada semestre contam com um máximo de 50 alunos.

Nas três escolas as disciplinas têm duração semestral, mas a FEA-PUC-SP e a FEA-USP realizam um vestibular por ano, por isso as disciplinas oferecidas neste semestre são as de semestre ímpar do curso (diferentes do $2^{\circ}$ semestre), enquanto a FGV-EAESP realiza dois vestibulares por ano e por este motivo, em todos os semestres são oferecidas as disciplinas do $1^{\circ}$ ao $8^{\circ}$ semestre de curso. 
Ao citar as características de cada curso, nossa primeira reação é identificar as diferenças e semelhanças entre eles, mas o que "mais distingue" estes cursos dos demais? $\mathrm{Na}$ opinião dos professores respondentes, é a qualidade dos alunos, que foi citada por treze professores, e a competência do corpo docente, com cinco citações. Por outro lado, onze professores expressaram a falta de conhecimento dos outros cursos para poder fazer alguma comparação entre eles.

Nas próximas seções esses três cursos são comparados quanto à estrutura curricular, o conteúdo obrigatório de APO, a bibliografia, a metodologia de ensino e sistema de avaliação, e a organização do corpo docente.

\subsection{APO na estrutura curricular do curso de Administração}

A comparação da estrutura curricular (grade de disciplinas) das três escolas foi limitada às disciplinas da área de $\mathrm{APO}$, que resultou no quadro 9, evidenciando as características a seguir:

- Os três cursos possuem a mesma quantidade de disciplinas obrigatórias, mas as cinco da FEA-PUC-SP totalizam 300 horas-aula, enquanto as da FEA-USP e da FGVEAESP totalizam 240 horas.

- Na FEA-PUC-SP as disciplinas obrigatórias de APO se concentram no final do curso $\left(3^{\circ}\right.$ e $4^{\circ}$ ano), enquanto na FEA-USP se concentram no meio do curso ( $3^{\circ}$ ano) e na FGV-EAESP no início e meio de curso ( $1^{\circ}$ e $3^{\circ}$ ano). Como as disciplinas de APO são profissionalizantes, era esperado que elas estivessem programadas para o meio ou final de curso, o fato da FGV-EAESP ter disciplinas de APO desde o primeiro semestre foi explicado pelo ex-coordenador das disciplinas de graduação da seguinte forma:

Há seis anos que temos oferecido as disciplinas de APO no início do curso. O principal objetivo de termos feito esta alteração foi o de atrair os alunos iniciantes para a área de produção, por isso, na disciplina Administração da Produção I apresentamos em linhas gerais "O que?" é tratado em APO e em Administração da Produção II o "Como?", isto é uma forma de "vender" APO para os alunos antes que eles se interessem por outras áreas ou pensem que APO é coisa para engenheiro. 
- Apenas a FGV-EAESP tem mantido a disciplina Engenharia Econômica no Departamento de Produção. Na FEA-USP este conteúdo já pertenceu à Área de Produção, mas atualmente é ministrado por professores da Área de Finanças.

- Como a FEA-PUC-SP não possui uma área específica para métodos quantitativos como a FEA-USP e a FGV-EAESP, as disciplinas Matemática e Estatística são ministradas por professores do Departamento de Ciências Contábeis e Atuariais e a disciplina Processos de Decisões Operacionais (conteúdo de Pesquisa Operacional) é ministrada por professores da Área de Produção.

- Se desconsiderarmos a disciplina de Engenharia Econômica do programa da FGVEAESP e a disciplina Processos de Decisões Operacionais do programa da FEA-PUCSP, obtemos as seguintes cargas horárias totais: FEA-USP e FEA-PUC-SP com 240 horas e FGV-SP com 210 horas.

- Os pré-requisitos das disciplinas de APO na FEA-USP também envolvem disciplinas da área de métodos quantitativos, enquanto no curso da FEA-PUC e da FGV-EAESP predominam como pré-requisitos as próprias disciplinas da área de APO. 
Quadro 9: Disciplinas de APO obrigatórias no curso de Administração

\begin{tabular}{|c|c|c|c|}
\hline \multicolumn{4}{|c|}{ FEA-PUC-SP } \\
\hline Semestre & Disciplina & Pré-requisitos & $\begin{array}{c}\text { Carga } \\
\text { horária }\end{array}$ \\
\hline $5^{\circ}$ & $\begin{array}{l}\text { PDO - Processo de decisões } \\
\text { operacionais }\end{array}$ & Sem pré-requisitos & 60 \\
\hline $6^{\circ}$ & $\begin{array}{l}\text { ADP I - Administração da } \\
\text { Produção I }\end{array}$ & Sem pré-requisitos & 60 \\
\hline $7^{\mathrm{o}}$ & $\begin{array}{l}\text { ADP II - Administração da } \\
\text { Produção II }\end{array}$ & ADP I & 60 \\
\hline $8^{\circ}$ & $\begin{array}{l}\mathrm{ADM} \text { - Administração de } \\
\text { materiais }\end{array}$ & Sem pré-requisitos & 60 \\
\hline $9^{\circ}$ ou $10^{\circ}$ & $\begin{array}{l}\text { Obrigatório fazer uma disciplina } \\
\text { de APO optativa no } 9^{\circ} \text { ou } 10^{\circ} \\
\text { semestre }\end{array}$ & Todas da área de Produção & 60 \\
\hline \multicolumn{4}{|c|}{ FEA-USP } \\
\hline Semestre & Disciplina & Pré-requisitos & $\begin{array}{c}\text { Carga } \\
\text { horária }\end{array}$ \\
\hline $\begin{array}{c}3^{\mathrm{o}} \\
\left(4^{\mathrm{o}} \text { Not.) }\right.\end{array}$ & $\begin{array}{l}\text { EAD } 0660 \text { - Projeto de sistemas } \\
\text { de produção (antiga 461) }\end{array}$ & $\begin{array}{l}\text { EAD } 0630 \text { - Matemática aplicada a } \\
\text { finanças } \\
\text { MAE } 0116 \text { - Noções de estatística }\end{array}$ & 60 \\
\hline $\begin{array}{c}5^{\mathrm{o}} \\
\left(6^{\mathrm{o}} \mathrm{Not}\right)\end{array}$ & $\begin{array}{l}\text { EAD } 0661 \text { - Planejamento, } \\
\text { programação e controle da } \\
\text { produção (antiga 462) }\end{array}$ & $\begin{array}{l}\text { EAD 0630, MAE 0116, EAD } 0660 \\
\text { e EAD } 0650 \text { - Programação } \\
\text { Matemática }\end{array}$ & 60 \\
\hline $\begin{array}{c}5^{\mathrm{o}} \\
\left(8^{\mathrm{o}} \text { Not. }\right)\end{array}$ & $\begin{array}{l}\text { EAD } 0662 \text { - Administração de } \\
\text { Recursos Produtivos (antiga 463) }\end{array}$ & $\begin{array}{l}\text { EAD 0630, MAE 0116, EAD } 0660 \\
\text { e EAD } 0650\end{array}$ & 30 \\
\hline $\begin{array}{c}6^{\circ} \\
\left(9^{\circ} \text { Not. }\right) \\
\end{array}$ & $\begin{array}{l}\text { EAD } 0465 \text { - Qualidade e } \\
\text { produtividade }\end{array}$ & $\begin{array}{l}\text { EAD 0630, MAE 0116, EAD 0660, } \\
\text { EAD 0650 e EAD } 0661\end{array}$ & 60 \\
\hline $\begin{array}{c}6^{\circ} \\
\left(9^{\circ} \text { Not. }\right) \\
\end{array}$ & $\begin{array}{l}\text { EAD } 0667 \text { - Logística e cadeia de } \\
\text { suprimentos (antiga 464) }\end{array}$ & $\begin{array}{l}\text { EAD 0630, MAE 0116, EAD 0660, } \\
\text { EAD } 0650 \text { e EAD } 0662\end{array}$ & 30 \\
\hline \multicolumn{4}{|c|}{ FGV- EAESP } \\
\hline Semestre & Disciplina & Pré-requisitos & $\begin{array}{c}\text { Carga } \\
\text { horária }\end{array}$ \\
\hline $1^{\mathrm{o}}$ & $\begin{array}{l}\text { 122-31 - Administração da } \\
\text { Produção I }\end{array}$ & Sem pré-requisitos & 60 \\
\hline $2^{\circ}$ & $\begin{array}{l}\text { 4-31 - Administração da Produção } \\
\text { II }\end{array}$ & $122-31$ & 60 \\
\hline $3^{\circ}$ & 26-31 - Engenharia Econômica & 50-31 - Matemática II & 30 \\
\hline $5^{\circ}$ & $\begin{array}{l}\text { 821-1 - Administração de material } \\
\text { e compras }\end{array}$ & Sem pré-requisitos & 60 \\
\hline $6^{\mathrm{o}}$ & $\begin{array}{l}\text { 55-31 - Planejamento e controle } \\
\text { da Produção }\end{array}$ & $821-1$ & 30 \\
\hline
\end{tabular}


Os três cursos possuem disciplinas optativas de APO, mas o tratamento dado a elas é muito diferente:

- A FEA-USP está oferecendo pela primeira vez uma disciplina optativa no $7^{\circ}$ semestre: Tópicos de Produção e Operações I.

- Na FEA-PUC-SP todos os alunos devem cursar, pelo menos, uma das oito disciplinas optativas: Administração de serviços, Cadeia de suprimentos, Competitividade empresarial, Estratégias operacionais, Gestão da qualidade, Gestão de operações em Micro, Pequenas e Médias Empresas, Logística nas organizações e Técnicas inovadoras.

- Na FGV-EAESP os alunos devem cursar 28 créditos em disciplinas eletivas e 12 créditos em disciplinas Trilha, sendo 4 créditos no $6^{\circ}$ semestre, 4 no $7^{\circ}$ e 4 no $8^{\circ}$ semestre. As disciplinas Trilha são indicadas pelos departamentos para votação dos alunos e as três mais votadas são oferecidas no próximo semestre. Neste momento não está sendo oferecida nenhuma disciplina Trilha da área de APO, enquanto o departamento de Contabilidade, Finanças e Controle (CFC) está com disciplinas programadas para 17 horários.

Em linhas gerais, essas são as principais diferenças na estrutura curricular dos três cursos, a seguir são apresentados os resultados da análise de conteúdo dos programas das disciplinas obrigatórias e a comparação com os resultados obtidos na análise dos livros didáticos e na análise do Provão.

\subsection{Conteúdo obrigatório de APO}

Como foi apresentado no capítulo 2, o questionamento sobre o conteúdo de APO tem sido uma constante nas pesquisas das últimas cinco décadas. O pioneiro foi Goetz (1959) quando procurou definir um método para se estabelecerem os conteúdos a serem ensinados ou pesquisados. Na verdade, a idéia era simples: dadas as responsabilidades e os problemas que os gerentes confrontam no desempenho de suas funções, quais as técnicas e ferramentas mais adequadas que estão disponíveis? Neste método, o tempo foi considerado como a quarta dimensão, reconhecendo desta forma a evolução das responsabilidades, problemas e técnicas ou ferramentas. 
Apesar de Goetz não ser citado em várias pesquisas, é possível observar que este método (ou idéia) é comum a muitas que levaram em conta a opinião dos gerentes e profissionais da área de APO. Por outro lado, as demais pesquisas que tratam do conteúdo têm, historicamente, se baseado no currículo das disciplinas.

Os trabalhos de Santi Filho (1981) e Pilão (1987) são os que mais se aproximam da presente pesquisa, mas a comparação direta não pode ser feita porque a população de interesse era diferente. Mesmo assim, é interessante destacar alguns resultados.Em 1981, por exemplo, a carga horária dedicada às disciplinas de Administração da Produção e Administração de materiais totalizavam 176 horas (média de 16 programas) e em 1987 esse número subiu para 186 horas (média de 34 programas). Atualmente, a média da FEAPUC-SP, FEA-USP e FGV-EAESP é de 230 horas, excluindo dessa média as disciplinas "Processo de decisões operacionais" da FEA-PUC-SP e "Engenharia Econômica" da FGVEAESP.

Excluindo as horas dedicadas ao estágio, ao trabalho de conclusão do curso (TCC) e às aulas de Educação Física da carga horária total do curso, calcula-se que as disciplinas obrigatórias de APO representam 8,33\% do curso de Administração da FEA-USP, 8,89\% do curso da FGV-EAESP e 10,31\% da FEA-PUC-SP.

Voltando à evolução das pesquisas sobre o conteúdo, é de reconhecer-se que a importância da recomendação de Goetz (1959) e de outros tantos sobre a necessidade de incluir os praticantes no questionamento sobre os conteúdos de APO, porém, para esta pesquisa adotou-se a análise do currículo porque, na verdade, não se está questionando qual conteúdo "deveria" ou não ser ministrado, mas sim qual o conteúdo que está sendo ministrado neste momento, nessas escolas? Nos parágrafos a seguir, serão apresentados os resultados obtidos.

Os programas das 14 disciplinas citadas no quadro 9 foram analisados quanto ao conteúdo, de forma semelhante à análise dos conteúdos dos livros didáticos, mas com a diferença de que foram utilizadas as categorias (tópicos) que já tinham sido definidas na análise dos livros para iniciar a análise dos programas, sendo acrescentados novos tópicos quando necessário. 
Desta forma, alguns tópicos que tinham sido categorizados na análise dos conteúdos dos livros didáticos não tiveram nenhuma citação nos programas analisados, enquanto outros tiveram até cinco citações. A análise de freqüências permitiu a classificação dos tópicos de uma forma comparável àquela feita na análise dos conteúdos dos livros, a saber: tópicos principais, tópicos secundários e tópicos opcionais.

Foram considerados como principais os tópicos citados em dois ou mais programas. O resultado obtido é praticamente igual à lista obtida na análise dos conteúdos dos livros, com exceção de dois tópicos: não estava explicitado nos programas o tópico "Tecnologia (informação, produção, processo, CAD, CAM, CIM,...)", entretanto foi citado nos programas das três escolas o tópico "Compras (recursos, administração, aquisição, negociação, organização, codificação)".

Com a exclusão de um tópico e a inclusão de outro, a lista continuou com 26 tópicos principais, sendo eles:

- Introdução a APO (histórico, importância, conceitos, produto X serviço)

- Competitividade e estratégia de produção

- Engenharia econômica (ponto de equilíbrio, VPL, Depreciação...)

- Planejamento e controle da capacidade

- Localização

- Projeto do produto / serviço

- Projeto do processo (seleção, desenvolvimento)

- Arranjo físico (layout)

- Projeto e medida do trabalho (estudo de tempos) + Aspectos de RH em APO

- Previsão

- Planejamento agregado e Plano mestre de produção

- MRP

- MRP II, ERP

- Planejamento, programação e controle da produção / operações

- Administração de projetos: PERT e CPM

- Gestão de estoques

- Compras (recursos, administração, aquisição, negociação, organização, codificação)

- Administração da cadeia de suprimentos

- Logística, movimentação e armazenagem de materiais

- Sistemas just-in-time

- Teoria das restrições (TOC, gargalos, OPT - Optimized Production Tecnology, manufatura síncrona)

- Qualidade: introdução, histórico, abordagens, gurus, conceitos.

- Qualidade: CEP

- Qualidade: melhorias nos processos, PDCA, 7 ferramentas

- Qualidade: TQM, ISO, Prêmios da Qualidade 
- Medida de produtividade

Além de este resultado ser coerente com os resultados da análise dos livros didáticos, também é coerente com os resultados da análise das questões do Provão e com as respostas dos professores, quando afirmam que o Provão não teve influência na definição do conteúdo a ser ministrado porque "as questões tratadas no provão são muito básicas".

A coerência também é encontrada quando se compara esta lista com os resultados encontrados em outras pesquisas.Em Machuca e Luque (2003), por exemplo, foram encontrados 28 tópicos que constavam em pelo menos metade dos programas analisados: JIT, Qualidade, Estratégias de operações, MRP/ERP, Capacidade, Gestão de processo, Plano mestre e agregado, Localização, Projeto do produto, Sistemas de estoque para demanda independente, Problemas-chave de APO, Layout, Administração de projetos, Programação, História da APO, Previsão de demanda, Projeto e medida do trabalho e Teoria das restrições.

Continuando a análise, os tópicos com apenas uma citação foram classificados como "secundários", isso não quer dizer que tenham menor importância, mas sim que a ênfase dada por uma escola tem sido diferente da outra, como é apresentado a seguir. Destacando que os cinco primeiros tópicos também tinham sido classificados como secundários na análise dos conteúdos dos livros didáticos:

- Métodos quantitativos: programação linear

- Métodos quantitativos: teoria da decisão

- Métodos quantitativos: filas de espera (teoria das filas)

- Métodos quantitativos: simulação

- Desafios e tendências na área de APO

- Métodos quantitativos: construção de modelos

- Contabilidade geral, Administração financeira, Contabilidade de custos

- Programação dinâmica (FEA-PUC-SP)

- Teoria dos jogos (FEA-PUC-SP)

- Administração de filas (FEA-USP)

- Gestão ambiental e segurança do trabalho (FEA-USP)

- Qualidade em serviços (FEA-USP)

- Seis sigma (FEA-USP)

- Matemática financeira (equivalência de capitais, análise de investimento, substituição de equipamentos, compra X aluguel, inflação) (FGV-EAESP)

- Disciplina prática: elaborar Plano Gerencial: visitas, MS-Project... (FGV-EAESP) 
Finalmente, quatro tópicos classificados como opcionais na análise do conteúdo dos livros didáticos nem foram citados nos programas analisados, a saber: Informações para a empresa, Estatística básica, Marketing industrial, 5S e Housekeeping. Esse resultado confirma a observação que já tinha sido feita, ou seja, de que estes conteúdos deveriam ser tratados em outras áreas, como é o caso da Estatística Básica, ou como sub-item de um tópico que tinha sido classificado como principal ou secundário, como é o caso de $5 \mathrm{~S}$ e housekeeping, que podem ser tratados no tópico principal "Qualidade: TQM, ISO, Prêmios da Qualidade".

A última observação do parágrafo anterior nos remete a uma limitação inerente ao processo de categorização dos conteúdos, ou seja, apesar de ser verificada a existência ou não daquele tópico no conteúdo em análise, não é considerada a "intensidade". Por exemplo, o tópico "Administração da cadeia de suprimentos" consta nos programas das três escolas, mas a profundidade com que é tratado difere de um modo que chamou a atenção:

- FEA-PUC-SP: o programa da disciplina Administração de Materiais (ADM) foca na gestão de estoques na cadeia logística (tipos de cadeias logísticas, objetivos, lead times, custos e indicadores de performance).

- FEA-USP: na disciplina Administração de Recursos Produtivos (EAD 662), é usado o jogo da cerveja para discutir os conceitos de lead time, atrasos, demanda variável, filas e capacidade de atendimento, enquanto a disciplina Logística e Cadeia de Suprimentos (EAD 667), apesar do nome, foca mais a atividade de compras, com os seguintes conteúdos:

○ Introdução, definições e conceituações

- Operação de compras

- Quanto e quando comprar

- Políticas de suprimento

- Administração dos serviços de compras

- Organização / organograma

- Sistema de compras

- Negociação

- FGV-EAESP: Na disciplina Administração de material e compras (821-1) é abordado praticamente todo o conteúdo do livro de Chopra e $\mathrm{Meindl}^{12}$, com os seguintes conteúdos:

○ Compreendendo a cadeia de suprimento

12 CHOPRA, S.; MEINDL, P. Gerenciamento da cadeia de suprimentos: estratégia, planejamento e operações. São Paulo: Prentice Hall, 2003. 
○ O desempenho da cadeia de suprimento

- Fatores-chave e obstáculos

- Previsão da demanda

- Planejamento agregado na cadeia de suprimento

- Planejando suprimento e demanda

- Gerenciando economias de escala

- Gerenciando a incerteza

- MRP e ERP

- Transporte em uma cadeia de suprimento

- Tecnologia da informação em uma cadeia de suprimento

- Coordenação na cadeia de suprimento

- E-business e a cadeia de suprimento

Encerrando esta seção com a ressalva de que o projeto inicial da tese não contemplava a comparação dos resultados com os cursos estrangeiros, mas como houve mais de uma recomendação na fase de coleta de dados e validação para que se procurasse informações sobre os cursos americanos foram acrescentados os parágrafos a seguir.

O levantamento de dados sobre os cursos estrangeiros foi feito exclusivamente através da homepage das oito escolas americanas e uma inglesa. Conforme o levantamento de dados prosseguia, percebeu-se que talvez o único ponto em comum com os cursos paulistas seja a divisão das disciplinas em regime semestral.

Após as "visitas virtuais" às oito escolas americanas, foi possível perceber que estavam se destacando duas características: em primeiro lugar, alguns cursos não possuem disciplinas obrigatórias de APO ou apenas uma disciplina de 30 a 60 horas com o conteúdo básico de APO; em segundo lugar, a maior parte das disciplinas são eletivas e, em alguns casos, o aluno decide por determinada "concentração" (um grupo de disciplinas). Nos parágrafos a seguir são comentados os cursos analisados.

Harvard Business School, Stanford Graduate School of Business (Stanford University) e Columbia Business School (Columbia University) são três instituições que mantêm apenas cursos em nível de pós-graduação: doutorado, MBA e cursos para executivos. 
O curso de Management Science da Sloan School of Management (MIT Massachusetts Institute of Technology) é muito diferente dos cursos analisados e oferece concentração nas seguintes áreas: Finanças, Tecnologias da informação, Marketing e Pesquisa operacional. O programa é flexível e oferece dezessete disciplinas de APO.

No curso de Administração da Haas School of Business (Universidade da California - Berkeley) são oferecidas quatorze disciplinas obrigatórias e 46 disciplinas eletivas, duas delas da área de APO: Administração da produção e operações e Previsão para decisões gerenciais, ambas com sessenta horas.

A McLaren College of Business (Universidade de San Francisco) e a School of Management (UTD - University of Texas at Dallas) oferecem apenas a disciplina Administração da produção em seus cursos de Administração, com uma carga horária de três horas semanais.

Apesar de o curso da Wharton School (Universidade da Pennsylvania) ser voltado para "negócios", o título que o aluno obtém ao se formar é Bacharel em Ciências Econômicas. O curso possui dezenove áreas de concentração e a disciplina Administração de operações e informações é ministrada para todos os alunos. Para aqueles que optam pela concentração em Administração não é oferecida mais nenhuma disciplina de APO e para os alunos que optam pela concentração em Administração de operações e informações há mais três opções (tracks): Processo de decisão, Sistemas de Informação ou Administração da Produção e Management Science (OR/MS). Cada opção (track) é formada por um grupo de quatro disciplinas, sendo uma ou duas obrigatórias e as demais escolhidas de um grupo de quatro a nove disciplinas eletivas.

Como o "Slack" tem sido o livro mais citado nos programas analisados (próxima seção) foi decidido "visitar" a escola do professor Nigel Slack, a Warwick Business School (Warwick University) e verificou-se que o curso de Administração não possui disciplinas obrigatórias de APO e as seis disciplinas optativas têm uma carga horária de duas horas semanais, a saber: Administração de operações, Administração de operações de serviços, Estratégia de operações, Administração de projetos, Administração da qualidade e Administração da cadeia de suprimentos. 
Pode-se concluir esta seção sintetizando que FEA-PUC-SP, FEA-USP e FGVEAESP possuem cargas horárias de APO similares, seus conteúdos obrigatórios convergiram para 26 tópicos principais, sendo 25 coincidentes com a análise dos livros didáticos e que os cursos estrangeiros são estruturados com pouco conteúdo obrigatório de APO, mas coerentes com os conteúdos dos cursos paulistas.

\subsection{Bibliografia de APO}

Alguns planos de ensino (ou programa) citavam apenas "Bibliografia" e outros separavam em "Bibliografia básica" e "Bibliografia complementar ou suplementar". Nesta análise todas as recomendações foram consideradas simplesmente como "Bibliografia". Além de livros, três disciplinas da FGV-EAESP também utilizam apostilas preparadas pelos próprios professores e, apesar de artigos serem utilizados em várias disciplinas, apenas dois programas os citavam. Os programas das disciplinas da FEA-PUCSP e da FEA-USP não indicavam apostilas ou artigos, embora os professores tenham respondido que usam casos.

$\mathrm{Na}$ primeira análise da bibliografia recomendada, foram consideradas todas as disciplinas da FEA-PUC-SP, da FEA-USP e da FGV-EAESP, chegando-se ao total de 51 referências. Na segunda análise foram excluídas as disciplinas: Processos de Decisões Operacionais (PDO) da FEA-PUC-SP e Engenharia Econômica da FGV-EAESP, resultando num total de 45 referências, o que equivale a uma média de cinco a seis referências por disciplinas.

Dos 45 livros, doze foram recomendados em pelos menos dois programas:

- Com nove indicações: SLACK, N.; CHAMBERS, S.; HARTLAND, C.; JOHSTON, R. Administração da Produção. São Paulo: Atlas, 2002.

- Com cinco indicações: GAITHER, N.; FRAZIER, G. Administração da Produção e Operações. São Paulo: Pioneira, 2001.

- MOREIRA teve quatro indicações, sendo duas para "MOREIRA, Daniel A. Administração da Produção e Operações. São Paulo: Pioneira, 1993.” e duas para "MOREIRA, D. Introdução à Administração da Produção e Operações. São Paulo: Pioneira, 1998." 
- Com três indicações: AQUILANO, N. J.; CHASE, R. B.; DAVIS, M. M. Fundamentos da Administração da Produção. São Paulo: Bookman, 2000. Os sete livros a seguir foram indicados em duas disciplinas.

- MEREDITH, J. R.; SHAFER, S. M. Administração da Produção para MBAs. São Paulo: Bookman, 2002.

- GOLDRATT, E. M. A meta. São Paulo: Ed. Educator, 2000.

- LAUGeni, F. P.; MARTins, P. G. Administração da Produção. São Paulo: Saraiva, 1998.

- CORRÊA, H. L., GIANESI, I. G. N. Just in time, MRP II e OPT - um enfoque estratégico. $2^{a}$ Edição. São Paulo: Atlas, 1994.

- CORRÊA, H. L., GIANESI, I. G. N. e CAON, M. Planejamento, programação e controle da produção. São Paulo: Atlas, 1997.

- MONKS, J. G. Administração da Produção. São Paulo: McGraw-Hill, 1987.

- SCILlAG, João Mário. Análise do valor. São Paulo: Atlas, 1986.

Numa terceira análise foram consideradas apenas as disciplinas de APO de um modo geral, isto é, além das duas que já tinham sido desconsideradas, também foram retiradas as disciplinas ligadas à Administração de Materiais. Obtendo pequenas diferenças nos resultados anteriores: os onze livros mais indicados foram os mesmos, a quantidade de livros indicados caiu para 34 e a média de livros por disciplina aumentou para 6,4.

Na última análise foram consideradas apenas as disciplinas ligadas à Administração de Materiais, quando foi possível observar que além da média de livros por disciplina cair para 4,3, não há um consenso sobre qual livro deveria ser adotado para Administração de Materiais, já que apenas o "SLACK" recebeu três indicações e os outros 14 livros recomendados receberam apenas uma indicação cada.

Apesar de o trabalho de Pilão ser de 1987, os resultados aqui conseguidos são coerentes com o que ele tinha obtido, quando relatou que para as 34 IES's tinham sido citados 50 livros para a disciplina Administração da produção e 40 para Administração de materiais, porém, mais da metade com apenas uma indicação. 
Finalmente, observamos que apesar do livro de Stevenson (2002) estar traduzido e ter sido considerado um dos mais completos na análise feita no capítulo 4 , ele não foi indicado em nenhuma disciplina.

\subsection{Metodologia de ensino e sistema de avaliação}

As informações sobre a metodologia de ensino e o sistema de avaliação de cada escola foram obtidas através dos planos de ensino e também pelas respostas ao questionário enviado aos professores. Vinte professores (49\%) responderam o questionário de um total de 41, sendo treze da FEA-PUC-SP, seis da FEA-USP e 22 professores da graduação da FGV-EAESP.

Nas três escolas há um predomínio das aulas expositivas, mas o uso de determinados recursos e a participação dos alunos na forma de preparação e apresentação de trabalhos, bem como o sistema de avaliação adotado por professor, tornam a presente comparação grosseira, dada a infinidade de detalhes que poderiam ter sido considerados.

Apesar dessa limitação, podem-se elaborar algumas considerações sobre os recursos utilizados em sala de aula. Na FEA-PUC-SP e na FEA-USP, por exemplo, é possível utilizar-se do canhão multimídia através do sistema de reserva, enquanto na FGVEAESP este recurso está disponível em todas as salas de aula. Por esse motivo, todos os professores têm utilizado o canhão e mais de $80 \%$ deles não têm utilizado o retroprojetor, enquanto nas duas primeiras o uso do retroprojetor e do canhão multimídia é moderado.

De modo geral, metade do número de professores têm utilizado jogos e simulações com e sem computador, enquanto um terço deles têm se utilizado de visitas às empresas como complemento às aulas. Filmes, palestras de profissionais e seminários para a discussão dos trabalhos dos alunos têm sido utilizados pela maioria dos professores. 
Nos três cursos há esforços para a integração das disciplinas de APO entre si e com as demais disciplinas. Por exemplo, no planejamento e atualização das disciplinas obrigatórias é verificada a complementaridade dos conteúdos (integração entre as disciplinas de APO). Para a integração das disciplinas de APO com as demais, há esforços de todos os departamentos ou áreas, e no caso da área de produção citam-se:

- No curso da FEA-PUC-SP a integração dos conteúdos de Produção com as demais áreas é discutida na disciplina Gestão da qualidade, em Jogos de empresas e também nas discussões de casos;

- Durante a disciplina Qualidade e produtividade, os alunos do curso de Administração da FEA-USP desenvolvem um projeto com todos os sistemas da empresa, sendo incentivados a discutir tópicos que envolvem disciplinas de outras áreas, como finanças, $\mathrm{RH}$ ou marketing;

- Alguns professores da FGV-EAESP utilizam projetos e planos gerenciais desenvolvidos pelos alunos, como uma forma de integração dos conteúdos de produção com os de outras áreas, tal como na disciplina Gestão de Projetos.

Quanto ao sistema de avaliação, praticamente todos os professores adotam uma combinação de prova e mais algum expediente como: resumo de textos, resumo e discussão de casos, exercícios feitos em aula, testes rápidos (quizzes), provas parciais, provinhas semanais, relatório de trabalho de campo, seminários e trabalho em grupo.

Os professores foram unânimes ao responderem que o Provão não teve influência alguma na metodologia de ensino ou no sistema de avaliação, o que é coerente com o resultado obtido na pesquisa da ANGRAD, CFA e Ad Homines (on line, 2003, p.20), quando menciona que os cursos com conceitos A e B atribuem menor importância para a "revisão para o Provão" e a "elaboração de simulados para o Provão". 
Concluindo, há diferenças entre as metodologias de ensino entre os três cursos, mas quando são comparados com os resultados obtidos por Machuca e Luque (2003) para os cursos espanhóis, percebe-se que as diferenças não são tão grandes assim, ou seja, os três cursos analisados estão com mais e melhores recursos que os cursos espanhóis, com a ressalva de que os dados de Machuca e Luque foram levantados em 1998.

\subsection{Organização do corpo docente de APO}

Com base nos dados disponibilizados pelo INEP (on line, 2004d) foi feita uma comparação das quantidades de professores do curso de Administração de cada escola, bem como do regime de trabalho. A comparação inicial revelou grandes diferenças, que são comentadas nos próximos parágrafos. Para identificar as causas dessas diferenças e entender como o corpo docente está organizado, foram realizadas várias visitas, contatos telefônicos e por e-mail, bem como buscas pela Internet e biblioteca das próprias escolas. Os resultados são apresentados nas próximas seções.

As diferenças podem ser observadas na tabela 5, que apresenta os valores médios para o período de 1999 a 2003. Em primeiro lugar, a quantidade de professores: a FGV tem $70 \%$ a mais que a PUC e quase o triplo da FEA-USP. Em segundo lugar, a porcentagem de mestres e doutores: a FEA-USP tem 100\%, enquanto a FGV conta com $88 \%$ e a PUC com $70 \%$. Para as três escolas, mais de três quartos dos professores têm uma dedicação semanal de 20 horas ou mais, porém, 97\% ou mais dos professores das três escolas ministram menos de 20 horas-aula. 
Tabela 5: Titulação e regime de trabalho dos docentes das escolas pesquisadas

FEA-PUC-SP

FEA-USP

FGV-EAESP

\section{Distribuição dos Docentes pela Titulação}

\begin{tabular}{rccc}
\hline Total & 121 & 73 & 205 \\
\hline Doutores & $18 \%$ & $99 \%$ & $57 \%$ \\
\hline Mestres & $52 \%$ & $1 \%$ & $31 \%$ \\
\hline Especialistas & $24 \%$ & $0 \%$ & $1 \%$ \\
\hline Graduados & $6 \%$ & $0 \%$ & $11 \%$ \\
\hline
\end{tabular}

Distribuição dos Docentes pela Jornada de Trabalho

\begin{tabular}{rccc}
\hline 40 horas & $42 \%$ & $42 \%$ & $37 \%$ \\
\hline 20 a 39 horas & $39 \%$ & $33 \%$ & $51 \%$ \\
\hline 8 a 19 horas & $17 \%$ & $25 \%$ & $12 \%$ \\
\hline menos de 8 horas & $2 \%$ & $0 \%$ & $0 \%$ \\
\hline
\end{tabular}

Distribuição dos Docentes pelo Trabalho em Sala de Aula ${ }^{(1)}$

\begin{tabular}{rccc}
\hline 40 horas & $1 \%$ & $0 \%$ & $0 \%$ \\
\hline 20 a 39 horas & $2 \%$ & $3 \%$ & $0 \%$ \\
\hline 8 a 19 horas & $88 \%$ & $97 \%$ & $21 \%$ \\
\hline menos de 8 horas & $9 \%$ & $0 \%$ & $79 \%$ \\
\hline
\end{tabular}

Fonte: Elaborado pelo autor com os dados disponíveis em INEP (on line, 2004d)

Nota (1): A média da PUC foi calculada para os anos 2001 a 2003 porque os anos anteriores estavam muito discrepantes: $41,5 \%$ com 40 horas em 1999 e 33,6\% em 2000. Foi verificado que os professores contratados em regime de tempo integral (40 horas) têm um compromisso de, no máximo, dezesseis horas aula.

Os dados gerais mencionados acima introduzem a discussão sobre a organização do corpo docente e nas próximas seções será dado destaque para os docentes da Área de Produção. 


\subsubsection{Organização do corpo docente de APO na FEA-PUC-SP}

O departamento de Administração da FEA-PUC-SP é formado por 90 professores, sendo treze deles ligados à Área de Produção. Considerando-se as oito áreas do departamento, a Área de Produção ocupa o quarto lugar em número de professores (tabela 6). Conforme foi mencionado anteriormente, algumas disciplinas têm sido ministradas por professores de outros departamentos. Matemática e Estatística têm sido ministradas por professores do Departamento de Ciências Contábeis e Atuariais.

Tabela 6: Distribuição dos professores nas áreas do Departamento de Administração da FEA-PUC-SP em 2004

\begin{tabular}{|c|c|c|}
\hline Área & $\begin{array}{l}\text { Quantidade de } \\
\text { professores }\end{array}$ & $\%$ \\
\hline Produção & 13 & $14,4 \%$ \\
\hline Administração Geral & 22 & $24,4 \%$ \\
\hline Finanças & 14 & $15,6 \%$ \\
\hline Recursos Humanos & 8 & $8,9 \%$ \\
\hline Marketing & 20 & $22,2 \%$ \\
\hline Direito & 4 & $4,4 \%$ \\
\hline Sociologia & 4 & $4,4 \%$ \\
\hline Psicologia & 5 & $5,6 \%$ \\
\hline TOTAL & 90 & $\begin{array}{c}100,0 \\
\% \\
\end{array}$ \\
\hline MÉDIA & 11,25 & $12,5 \%$ \\
\hline
\end{tabular}

Fonte: Tabela preparada pelo autor com dados fornecidos pela secretaria do Departamento de Administração em 23/03/2004.

A Área de Produção é composta por treze professores, sendo seis em período integral (40 horas) e os demais com 10 a 30 horas de dedicação. Sete destes professores são engenheiros e três possuem título de doutor.

Todos os professores têm ministrado aulas na graduação, alguns têm aulas na especialização e apenas um professor ministra aulas no mestrado em Administração da PUC-SP. Como a especialização é coordenada pelo COGEAE (Coordenadoria Geral de Especialização, Aperfeiçoamento e Extensão) há a possibilidade de contratação de outros professores de APO fora da Área de Produção, apesar de isso ser incomum. 


\subsubsection{Organização do corpo docente de APO na FEA-USP}

Neste ano o Departamento de Administração da FEA-USP está com 74 docentes, sendo apenas seis da área de Produção e Operações (PROD). É possível observar na tabela 7 que esta área é a menor do departamento e se fosse considerado que algumas aulas são ministradas por professores de outros departamentos (Contabilidade e Economia) e até de outras unidades da USP (Matemática, Psicologia e Direito), a proporção (\%) seria menor ainda.

Tabela 7: Distribuição dos professores nas áreas do Departamento de Administração da FEA-USP em 2004

\begin{tabular}{|c|c|c|}
\hline Área & $\begin{array}{c}\text { Quantidade de } \\
\text { professores }\end{array}$ & $\%$ \\
\hline PROD - Produção e Operações & 6 & $8,1 \%$ \\
\hline ADMG - Administração Geral & 19 & $25,7 \%$ \\
\hline FIN - $\quad$ Finanças & 10 & $13,5 \%$ \\
\hline Recursos Humanos & 10 & $13,5 \%$ \\
\hline MQI - $\quad$ Métodos Quantitativos e Informática & 9 & $12,2 \%$ \\
\hline MKT - $\quad$ Marketing & 10 & $13,5 \%$ \\
\hline PNEE - Política de Negócios e Economia de Empresas & 10 & $13,5 \%$ \\
\hline TOTAL & 74 & $100 \%$ \\
\hline MÉDIA & 10,6 & $14,3 \%$ \\
\hline
\end{tabular}

Fonte: Tabela preparada pelo autor com dados fornecidos pela secretaria do Departamento de Administração em 09/03/2004.

A Área de Produção (PROD) é composta por seis professores, sendo dois em regime de turno completo ( $\mathrm{RTC}=20$ horas) e quatro em regime parcial ( $\mathrm{RP}=12$ horas). $\mathrm{O}$ único professor em regime de dedicação integral (RDIDP $=40$ horas) está afastado desde 2003.

Todos os professores da PROD são doutores e cinco deles são engenheiros. Neste momento apenas um deles tem participado da rotina administrativa da escola como vicecoordenador da graduação e chefe de Área, sendo que outros professores da área já atuaram na segunda função.

As aulas na graduação, no mestrado e no doutorado têm sido ministradas por quatro professores com oito horas-aula e dois com quatro horas-aula. As aulas da área de APO na especialização e MBA, em 2003, foram ministradas por cinco professores da Área de Produção da FEA e dois professores da Escola Politécnica da USP (EPUSP). 
Essa característica é muito importante na organização do corpo docente da FEAUSP, já que as Áreas coordenam as atividades ligadas à graduação, ao mestrado e ao doutorado, ficando os cursos de especialização e MBA a cargo da Fundação Instituto de Administração (FIA). Dessa forma, o aumento de cursos de especialização ou MBA refletem numa demanda direta por professores, mas não a ponto de aumentar o número de professores da Área, pois a FIA pode contratar professores de outras unidades da USP, em especial a EPUSP.

O fato de a EPUSP ter o curso de Engenharia de Produção (POLI-PRO) em nível de graduação e pós-graduação, bem como a especialização mantida pela Fundação Vanzolini, que também presta serviços de consultoria e certificação de sistemas de gestão da qualidade, faz com que vários projetos de consultoria que poderiam ser alocados à área de Produção da FEA-USP sejam encaminhados para os 42 professores da POLI-PRO. 


\subsubsection{Organização do corpo docente de APO na FGV-EAESP}

Atualmente a Escola de Administração de Empresas de São Paulo conta com $314^{13}$ professores, sendo que o Departamento de Produção e Operações (foi mantida a sigla POI, que originalmente significava Produção e Operações Industriais) está com 39 professores.

Na tabela 8 é possível observar que o POI está com seis professores abaixo da média, sendo o penúltimo departamento em número de professores, superando apenas a Mercadologia (MCD).

Tabela 8: Distribuição dos professores nos departamentos da FGV-EAESP em 2004

\begin{tabular}{l|c|c}
\multicolumn{1}{c|}{ Departamento } & $\begin{array}{c}\text { Quantidade de } \\
\text { professores }\end{array}$ & $\%$ \\
\hline POI - Administração da Produção e Operações & 39 & $12,4 \%$ \\
\hline ADM - Administração Geral e Recursos Humanos & 50 & $15,9 \%$ \\
\hline CFC - Contabilidade, Finanças e Controle & 45 & $14,3 \%$ \\
\hline FSJ - Fundamentos Sociais e Jurídicos & 52 & $16,6 \%$ \\
\hline IMQ - Informática e Métodos Quantitativos aplicados à Administração & 46 & $14,6 \%$ \\
\hline MCD - Mercadologia & 32 & $10,2 \%$ \\
\hline PAE - Planejamento e Análise Econômica & 50 & $15,9 \%$ \\
\hline TOTAL & $\mathbf{3 1 4}$ & $\mathbf{1 0 0 \%}$ \\
\hline MÉDIA & $\mathbf{4 4 , 9}$ & $\mathbf{1 4 , 3 \%}$ \\
\hline
\end{tabular}

Fonte: Tabela preparada pelo autor com dados fornecidos pela secretaria do POI em 08/03/2004.

O POI é composto por 28 professores em regime horista, denominados "Extracarreira" e onze (28\%) em regime integral (40 horas em dedicação exclusiva), denominados "Carreira".

Quanto à formação acadêmica, há uma predominância de engenheiros, sendo dez em dedicação exclusiva (91\% dos professores Carreira são engenheiros) e 19 em regime horista (68\% dos professores Extra-carreira são engenheiros), o que corresponde a $74 \%$ do total de professores do POI. Também se destaca a qualificação, sendo oito doutores em regime integral (73\% dos professores Carreira) e dez em regime horista $(36 \%$ dos professores Extra-carreira). No geral, 46\% dos professores do POI são doutores.

\footnotetext{
13 Naquela média de 205 professores do INEP (on line, 2004d) foram considerados apenas os professores da graduação.
} 
Normalmente as atividades administrativas e de coordenação são desenvolvidas por professores Carreira, mas os professores Extra-carreira também podem ocupar cargos de vice-coordenador e participar de algumas comissões (com ou sem remuneração extra). As atividades de orientação, consultoria e extensão podem ser exercidas pelos professores Carreira e Extra-carreira, desde que tenham os títulos necessários.

A cada semestre os professores Carreira ministram oito créditos (cada crédito equivale a quinze horas aula) nos cursos de graduação, especialização ou pós-graduação (mestrado e doutorado), enquanto os Extra-carreira estão com uma média de 3,8 créditos neste semestre (mínimo de 1 e máximo de 10), ou seja, no primeiro semestre de 2004 cada professor tem sido responsável por um a quatro horários com disciplinas de APO.

A quantidade de professores do POI, e mesmo dos outros departamentos, é facilmente justificada quando se verifica o número de disciplinas que são ministradas para uma variedade de turmas e horários em todos os níveis:

- Graduação: Administração Pública (CGAP) e Administração de Empresas (CGAE). Num total de vinte turmas com cinco disciplinas obrigatórias de APO e mais oito disciplinas eletivas, num total de 31 horários no primeiro semestre de 2004.

- Especialização: Administração para Graduados (CEAG em São Paulo, Campinas e São José dos Campos), Administração Hospitalar e de Sistemas de Saúde (CEAHS), Administração em Turismo e Hotelaria (CEAT), Administração de Negócios com Sistemas Integrados (CSI) e Negócios para Executivos, que tem sido oferecido na modalidade à distância, com encontros semanais ou quinzenais.

- MBA; Mestrado acadêmico; Mestrado profissional e Doutorado. 


\subsubsection{Comentários finais sobre a organização do corpo docente}

Esta seção tem o objetivo de finalizar a comparação da organização do corpo docente das três escolas pesquisadas. Para tanto, foi preparada a tabela 9, que é comentada nos parágrafos seguintes.

Tabela 9: Comparação quantitativa do corpo docente e disciplinas de APO - 2004

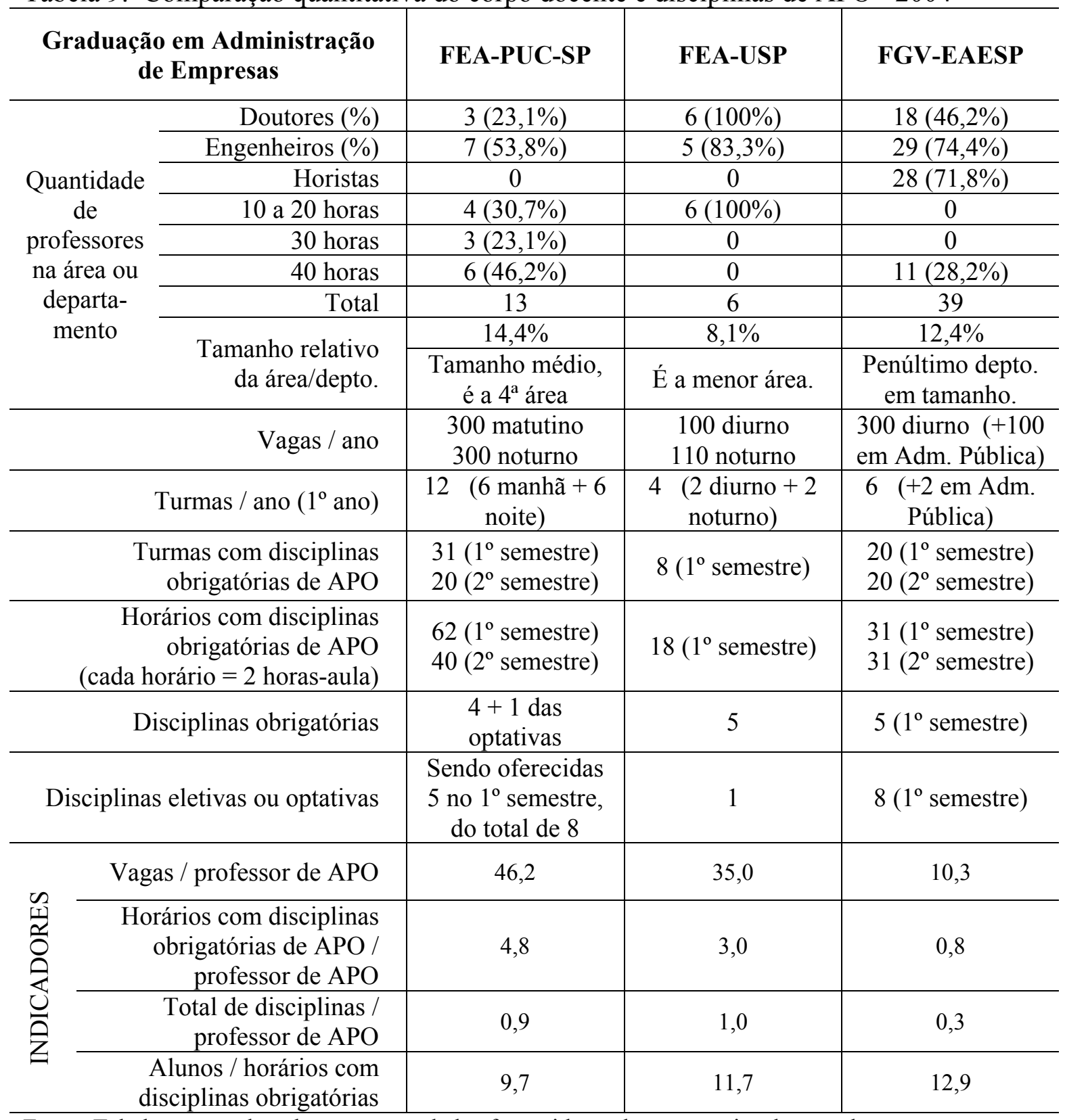

Fonte: Tabela preparada pelo autor com dados fornecidos pelas secretarias das escolas. 
A proporção de doutores nos Departamentos ou Áreas de Produção dessas escolas é coerente com aquela obtida no INEP e apresentada na tabela 5. A predominância de engenheiros também é alta nas três escolas.

O Departamento de Produção da FGV-EAESP é composto por 39 professores, que é o triplo da FEA-PUC-SP e 6,5 vezes maior que a Área de Produção da FEA-USP. Essa diferença também influi nos indicadores que dependem do número de professores de APO, e pode ser explicada por dois fatos, a saber: $31 \%$ dos professores possuem apenas um horário por semana e 43,6\% estão vinculados a outros cursos como: especialização, MBA e pós-graduação, sem horários na graduação. Em termos absolutos significa que dos 39 professores do Departamento de Produção:

- 17 deles não ministram aulas na graduação e ainda sete deles se dedicam apenas um horário por semana;

- 10 se dedicam apenas à graduação, sendo 5 deles em um horário por semana;

- os outros 12 se dedicam à graduação e aos demais cursos.

No caso da FEA-PUC-SP e da FEA-USP, a coordenação dos cursos de especialização é independente da estrutura (Áreas), isto é, há uma preferência por professores da Área de Produção da própria escola, mas é possível contratar professores externos, apenas para os cursos de especialização.

Na FEA-USP e na FGV-EAESP, o Departamento (ou Área) de Produção se destaca dos demais por ser um dos menores e no caso da FEA-USP a Área deveria ser 50\% maior para se igualar à segunda Área com menos professores, enquanto na FEA-PUC-SP, a Área de Produção possui um tamanho médio em relação aos demais.

$\mathrm{Na}$ estrutura curricular do curso da FEA-PUC-SP e da FGV-EAESP, constam oito disciplinas eletivas ou optativas de APO, enquanto no curso da FEA-USP está programada apenas uma disciplina optativa. Como o programa do curso é novo, esta disciplina ainda não foi oferecida e nem possui um programa ou plano de ensino estabelecido. Um maior número de disciplinas optativas poderia aumentar o interesse dos alunos pela área de APO, desde que os conteúdos estivessem definidos, para que eles pudessem fazer suas escolhas. Birochi (on line, 2000) e Vasconcellos e Mattar (1998) já tinham apontado a necessidade da FEA-USP contemplar mais disciplinas optativas. 
A oferta de mais disciplinas optativas não depende, necessariamente, da contratação de professores, porque poderia ser ministrada apenas a disciplina com maior procura. $^{14}$

Para a FEA-PUC-SP e a FEA-USP, os resultados indicam que, na média, cada professor de APO é responsável por uma disciplina, com dedicação de dois períodos por semana às aulas na graduação (4 horários de 2 horas-aula). Para a FGV-EAESP, o resultado de 0,8 para o indicador "horários / professor" é explicado pela presença de professores que não ministram aulas na graduação. Se forem considerados apenas os 22 professores da graduação, este indicador aumenta para 1,4, significando que, na média, cada professor tem uma dedicação de menos de um período por semana para o curso de graduação.

A quantidade de "alunos / horários com disciplinas obrigatórias" é similar para as três escolas, variando de dez a treze. O que era esperado, já que todas trabalham com turmas de 50 alunos e possuem cinco disciplinas obrigatórias com cargas-horárias semelhantes.

Finalizando este capítulo, é dado por atendido o objetivo geral que tinha sido proposto: comparar o ensino de APO na FEA-PUC-SP, FEA-USP e FGV-EAESP, quanto aos conteúdos, metodologias de ensino e organização do corpo docente. A seguir, serão discutidas as implicações desses resultados para o ensino de APO e as limitações desta pesquisa e também serão dadas algumas recomendações para futuras pesquisas.

\footnotetext{
14 Disciplina "optativa" e disciplina "eletiva" foram usadas neste trabalho como sinônimos para significar as disciplinas que o aluno decide cursar ou não, mas cada escola têm um tratamento diferenciado, por exemplo, na FGV-EAESP são oferecidas disciplinas Trilha e optativas a partir de um número mínimo de alunos interessados, o mesmo ocorre com as disciplinas optativas oferecidas pela FEA-PUC-SP. Em algumas escolas há uma distinção entre eletiva e optativa no sentido de que todas as optativas são oferecidas, independente da procura e as eletivas são oferecidas se houver um número mínimo de alunos interessados.
} 
CAPÍTULO 7

Conclusões 


\section{Conclusões}

Apesar das limitações quanto às escolas analisadas, foi possível identificar uma lista de conteúdos básicos de APO (tópicos principais) a partir da revisão da literatura, da análise dos livros didáticos, da análise do Provão e da análise dos programas da FEAPUC-SP, FEA-USP e FGV-EAESP.

Como esta lista convergiu de quatro análises independentes, é razoável concluir que se trata de um conteúdo que deveria fazer parte de qualquer curso de Administração em nível de graduação. Por outro lado, a análise dos cursos estrangeiros aponta para outra possibilidade, a de reduzir o conteúdo obrigatório de APO a um mínimo ou até eliminá-lo totalmente, tratando todo o conteúdo de APO em disciplinas optativas.

Para os cursos analisados, a carga horária média com disciplinas obrigatórias de APO foi de 230 horas, o que equivale a aproximadamente quatro disciplinas semestrais, com quatro aulas semanais cada, e apesar de o aluno não ter sido tratado nesta tese, foi possível observar que as disciplinas da área de APO não fazem parte de suas preferências, por isso, a diminuição da carga horária das disciplinas obrigatórias de APO deve ser uma decisão ponderada com muito cuidado, pois é grande a possibilidade de os alunos não cursarem as disciplinas de APO, se passarem a ser optativas.

Apesar dessa preferência ter sido citada pelos professores da área de APO, há outras evidências que confirmam esta opinião. Por exemplo, durante a elaboração do projeto de tese, foi possível entrevistar alguns alunos e professores fora da área de APO na FEA-USP, que confirmaram a preferência por disciplinas da área de Finanças. O mesmo ocorre na FGV-EAESP, já que neste semestre estão programados dezessete horários com disciplinas Trilha do Departamento de Contabilidade, Finanças e Controle, porém, não há nenhum horário com disciplinas Trilha de APO. 
Pilão (1987) iniciou a discussão sobre o papel do engenheiro de produção e o papel do administrador, infelizmente foge do escopo deste trabalho abordar esta questão, mas a "repulsa" dos alunos por APO pode indicar que continua havendo a "confusão" entre "Administração da produção" e "Engenharia da produção". No caso da FEA-USP, a situação é ainda mais crítica que nas outras duas escolas devido à presença da Escola Politécnica.

Quanto ao material didático, verificou-se que os livros brasileiros ou traduzidos contemplam todo o conteúdo básico de APO, além disso, os professores das escolas pesquisadas têm complementado seus cursos com apostilas e transparências (Power Point). Também foi observado que os livros brasileiros carecem de uma atualização, enquanto os livros traduzidos têm oferecido menos recursos de aprendizagem que os livros americanos.

Nas três escolas pesquisadas os professores têm utilizado uma extensa bibliografia, sendo que para as disciplinas de Administração da Produção o livro mais recomendado é o Slack et al. (2002), enquanto para as disciplinas ligadas à Administração de Materiais não há predominância de um livro em especial.

O método de ensino e o sistema de avaliação nas três escolas possuem vários pontos em comum, como o uso de jogos e simulações com e sem computador, visitas às empresas como complemento às aulas, filmes, palestras de profissionais, seminários para a discussão dos trabalhos dos alunos, com a avaliação sendo feita por uma combinação de métodos: provas, exercícios, quizzes, trabalhos de campo, trabalho em grupo, projetos, resumos e discussão de casos entre outros. Também foi observado que o Provão não tem sido utilizado como recurso didático por estas escolas.

Nas três escolas, os professores estão organizados em Áreas ou Departamentos, sendo que na FEA-USP e na FGV-EAESP, a área de Produção é uma das menores, enquanto na FEA-PUC-SP é de tamanho média em relação às outras áreas, havendo uma predominância de engenheiros na área de Produção. 
Em média, cada professor da FEA-PUC-SP é responsável por oito a dez aulas semanais (4,8 horários de duas aulas) na graduação, o que não deve representar uma carga excessiva já que $70 \%$ deles têm uma dedicação igual ou superior a trinta horas semanais. A FEA-USP está mais próxima do que ocorre na FEA-PUC-SP, os seis professores têm uma dedicação de doze a vinte horas semanais, com uma média de 3 horários por semana (6 aulas).

A FGV-EAESP está no outro extremo porque cada um dos 22 professores com aulas na graduação é responsável, na média, por duas a três aulas por semana (1,4 horário de duas aulas). A principal justificativa para este resultado é que dezesseis professores são horistas e cinco deles comparecem à FGV-EAESP em apenas um horário (duas aulas) por semana na graduação.

\subsection{Limitações}

Como os conteúdos básicos de APO (tópicos principais) convergiram de quatro análises independentes (revisão da literatura, análise dos livros didáticos, análise das questões do Provão e análise dos programas), as limitações relacionadas às escolas pesquisadas são minimizadas de modo que outras IES's ou autores de livros didáticos podem considerar a lista obtida como o núcleo de APO neste momento.

A questão da "perecibilidade" desse resultado já foi comentada em várias partes deste trabalho. Por exemplo, quando foi citado que Goetz $(1959,15)$ considerava o tempo como a quarta dimensão, apesar disso, é provável que o conteúdo básico de APO não sofra grandes alterações nos próximos cinco anos se a tendência for mantida, isto é, os resultados de Morris (1997) e de Goffin (1998) não são tão diferentes dos resultados obtidos nesta pesquisa. 
Uma especulação “óbvia” que pode gerar uma crítica importante à metodologia utilizada é a seguinte: os professores utilizam os livros didáticos como base para elaborar seus programas ou planos de ensino e a Comissão do MEC também utiliza os livros didáticos para elaborar as questões do Provão, daí a coerência dos resultados. Então como saber se o que está sendo ensinado é realmente o que deveria ser? A forma encontrada por vários pesquisadores é a verificação junto aos praticantes de APO (gerentes e diretores), o que não foi feito nesta tese e nem tinha sido proposto.

Para os outros resultados da pesquisa (bibliografia, metodologia de ensino, sistema de avaliação e organização do corpo docente) a generalização não é recomendada, já que os dados foram coletados apenas na FEA-PUC-SP, FEA-USP e FGV-EAESP. Apesar dessa ressalva, esses resultados podem ser úteis para outras IES's no momento da avaliação e planejamento de seus cursos.

O efeito do tempo, principalmente na metodologia de ensino e no sistema de avaliação, deve ser mais pronunciado, já que cada vez mais se têm utilizado recursos para o ensino à distância como uma forma de complementar o ensino presencial.

Outra limitação importante é o fato de o pesquisador ser aluno da FEA-USP desde 1995, de ter ministrado aulas na graduação na disciplina Qualidade e produtividade (EAD465) através do Programa de Aperfeiçoamento do Ensino (PAE), e de ter feito o projeto de tese com dados levantados na própria FEA-USP, o que resultou num conhecimento mais profundo do curso de Administração desta escola do que das outras duas. Apesar disso, os dados necessários para a tese foram levantados de maneira uniforme nas três escolas e a imparcialidade do pesquisador foi aferida através da etapa de validação, quando os resultados foram apresentados para crítica de alguns professores que participaram da pesquisa. 


\subsection{Recomendações}

Aprofundar a compreensão do ensino de APO implica recomendar pesquisas mais focadas ainda, em questões como, quais os recursos didáticos que têm sido utilizados para o ensino das disciplinas de APO? Nas escolas pesquisadas foram citados: simulação em computador (jogo da cerveja), dinâmica de grupos (simulação de uma operação), trabalhos de campo com visitas às empresas, desenvolvimento de Planos de negócio entre outros. Por um lado mais pragmático, os autores de livros didáticos poderiam sugerir e explicar o uso desses recursos em seus livros.

Investigar o efeito da organização do corpo docente (em áreas ou departamentos) e da estrutura do curso de administração, com sua divisão de disciplinas obrigatórias e optativas sobre o currículo de APO também é uma proposta interessante. Em alguns cursos estrangeiros, em especial aqueles denominados como Management Science, a área de Produção e Operações tem se apresentado agregada a uma ou duas áreas: Métodos Quantitativos (ou Pesquisa Operacional) e Informática (ou Sistemas de Informação), com uma grande quantidade de disciplinas optativas.

Para complementar os resultados deste trabalho, recomenda-se a pesquisa junto aos praticantes, o que é comum nos Estados Unidos, mas no Brasil apenas Pilão (1987) levantou este tipo de informação.

Para a área de APO também seria importante identificar a visão que os alunos de Administração e os professores de outras áreas têm sobre o papel do Engenheiro de produção e o papel do Administrador dentro da Administração da produção. Em 1987, Pilão alertou que o campo de trabalho de APO, principalmente os altos cargos, estava sendo ocupado por engenheiros, atualmente há indícios de que os alunos de Administração nem considerem APO como um campo de trabalho.

Para os autores brasileiros de livros didáticos de APO há duas recomendações:

- Atualizar os conteúdos, eliminando as lacunas identificadas no capítulo 4 e incluir casos brasileiros;

- Sugerir em seus livros quais capítulos deveriam ser abordados num curso de 60 horas, 120 horas ou 180 horas, como é feito por Moreira (2000, p. xi). Isso auxiliaria algumas IES's a estruturarem seus cursos de APO. 
REFERÊNCIAS 


\section{REFERÊNCIAS}

AACSB. Accreditation Standards. Disponível em: $<$ http://www.aacsb.edu/accreditation/ standards.asp $>$. Acesso em 21 fev. 2004a.

AACSB. About us. Disponível em: < http://www.aacsb.edu/aboutus.asp $>$. Acesso em 21 fev. 2004b.

AIEC. Portaria do MEC. Disponível em: < $\underline{\text { http://www.aiec.br/aiec/_1itt_portmec.htm> }}$ Acesso em: 21 Fev. 2004.

ALA, Mohammad. How students perceive the benefits of studying Production and Operations Management. Production And Inventory Management Journal, Alexandria; Fourth Quarter, Vol. 28, N 4, 1987, p. $71-74$.

ALVES, Flávia H. D. O livro didático de marketing como elemento de aperfeiçoamento da relação ensino-aprendizagem. Dissertação de mestrado. Faculdade de Economia, Administração e Contabilidade, USP, São Paulo, 2003.

AMATUCCI, Marcos. Perfil do Administrador brasileiro para o século XXI: um enfoque metodológico. Tese de doutorado. Faculdade de Economia, Administração e Contabilidade, USP, São Paulo, 2000.

ANGRAD - Associação Nacional dos Cursos de Graduação em Administração. Pesquisa PHAD/96 - Perfil e Habilidades do Administrador. 1996. Disponível em $<$ http://www.angrad.com/angrad/phad96.pdf $>$ Acesso em 03 Nov. 2003.

ANGRAD - Associação Nacional dos Cursos de Graduação em Administração. Bibliografia essencial. 1999. Disponível em $<$ http://www.angrad.com/angrad/ bibliogr.pdf> Acesso em 03 Nov. 2003.

ANGRAD; CFA; AD HOMINES. Alterações, efeitos e influências do Provão de Administração: a opinião dos coordenadores dos cursos de graduação. Mar. 2003. Disponível em $<$ http://www.angrad.com/angrad/Relatorio_pesquisa.pdf $>$ Acesso em 31 out. 2003.

ARMISTEAD, C.; JOHNSTON, R.;VOSS, A. Introducing service industries in operations management teaching. International Journal of Operations \& Production Management, Vol. 6, N 3, 1986, p. $21-29$.

APICS. About APICS. Disponível em $<$ http://www.apics.org/About/> Acesso em $21 \mathrm{fev}$. 2004.

BAHL, Harish C. Teaching Production And Operations Management at the MBA level: a survey. Production And Inventory Management Journal, Alexandria; Third Quarter; Vol. 30, N 3, 1989, p. $5-8$.

BANDYOPADHYAY, Jayanta K. Redesigning the POM major to prepare manufacturing managers of the 1990s. Production and Inventory Management Journal, Alexandria; First Quarter; Vol. 35, Nº 1, 1994, p. $26-30$. 
BENNET, D. Operations management: where have wee been and where are we going?. Operations \& Production, ABI/Proquest [?], 1999. (apud WOOD JR., 2001).

BERRY, Stephen E.; LANCASTER, Lilly M. Views of production practioners on the importance of selected POM topics: 1978 and 1989 practioners compared. Production And Inventory Management Journal, Second Quarter; Vol. 33, N², 1992, p. $24-31$.

BERRY, Stephen E.; WATSON, Hugh J.; GREENWOOD, William T. A survey as to the content of the introductory POM course. Academy of Management Journal, Vol. 21, $\mathrm{N}^{\mathrm{o}} 4,1978$, p. $699-714$.

BIDO, Diógenes de Souza. Implementação de sistemas da qualidade para a busca de certificação em pequenas e médias empresas do ramo automotivo. Dissertação de mestrado. Faculdade de Economia, Administração e Contabilidade, USP, São Paulo, 1999.

BIROCHI, René. Reflexões sobre a estrutura curricular para a educação superior: a necessidade de uma revisão no curso de Administração a partir de um enfoque transdisciplinar. Caderno de Pesquisas em Administração, Outubro-Dezembro de 2000, Vol. 7, No 4. Disponível em <http://www.ead.fea.usp.br/cad-pesq/index.htm>. Acesso em: 11 mar. 2003.

BRASIL. Biblioteca Básica para os cursos de graduação em Administração. Ministério da Educação, 1997?. Disponível em: <http://www.mec.gov.br/Sesu/cursos/ default.shtm>. Acesso em: 12 fev. 2004.

BRASIL. Parecer N N CNE/CES 0146/2002. Diretrizes Curriculares Nacionais. Ministério da Educação - Conselho Nacional de Educação. Aprovado em: 03 abr. 2002.

Disponível em: < http://www.mec.gov.br/cne/diretrizes.shtm\#administracao > Acesso em: 12 fev. 2004.

BRASIL. Parecer No CNE/CES 0067/2003. Referencial para as Diretrizes Curriculares Nacionais - DCN dos Cursos de Graduação. Ministério da Educação - Conselho Nacional de Educação. Aprovado em: 11 mar. 2003a. Disponível em: $<$ http://www.mec.gov.br/cne/diretrizes.shtm\#administracao $>$. Acesso em: 12 fev. 2004.

BRASIL. Parecer N ${ }^{\circ}$ CNE/CES 0134/2003. Diretrizes Curriculares Nacionais do curso de graduação em Administração. Ministério da Educação - Conselho Nacional de Educação. Aprovado em: 04 jun. 2003b. Disponível em: < $\underline{\text { http://www.mec.gov.br/cne/ }}$ diretrizes.shtm\#administracao >. Acesso em: 12 fev. 2004.

CARBONI, Irenice de Fátima. Uma análise dos programas da disciplina Informática nos cursos de graduação em administração na cidade de São Paulo. Dissertação de mestrado. Faculdade de Ciências Econômicas de São Paulo da Fundação Escola de Comércio Álvares Penteado, São Paulo, 2002.

CONTADOR, José C. (Coord.). Gestão de operações. 2a Ed. São Paulo: Edgard Blücher, 1998. 
CORRÊA, Henrique L.; GIANESI, Irineu G. N.; CAON, Mauro. Planejamento, programação e controle da produção: MRP II / ERP: conceitos, uso e implantação. $3^{\mathrm{a}}$ Ed. São Paulo: Ed. Atlas, 2000.

CRASP. Conselho Regional de Administração de São Paulo. Cursos de Administração no

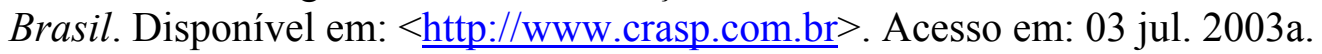

CRASP. Conselho Regional de Administração de São Paulo. Cursos de Administração no

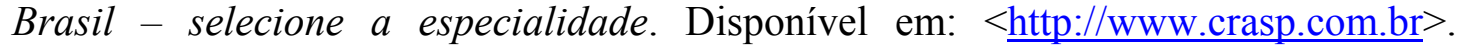
Acesso em: 13 jul. 2003b.

DAVIS, Mark M.; AQUILANO, Nicholas J.; CHASE, Richard B. Fundamentos da administração da produção. Porto Alegre: Bookman, 2001.

DEINES, Dan. Education Innovations. Journal of Accountancy, New York, V. 194, No 3, Setembro, 2002, p. 69-70.

DILWORTH, James B. Operations management: proving value in goods and services. $3^{\text {rd }}$ Ed. USA: Harcourt College Publishers, 2000.

DUCHARME, Richard E.; LEWIS, David A. The academic/practioner gap in production and inventory management. Production and Inventory Management. Vol 28, $\mathrm{N}^{\mathrm{o}} 1$, First Quarter 1987, p. 88 - 95.

EVANS, James R. Production/operations management: quality, performance and value. $5^{\text {th }}$ ed. Minneapolis: West Publishing Company, 1997.

FEA-USP. Credenciamento internacional. Disponível em: <http://www.ead.fea.usp.br/ DA/index.htm>. Acesso em: 21 fev. 2004).

FERREIRA, Ademir A.; REIS, Ana C. F.; PEREIRA, Maria I. Gestão Empresarial: de Taylor aos nossos dias: evolução e tendências da moderna administração de empresas. São Paulo: Pioneira, 1997.

FGV-SP. Reconhecimentos Internacionais da qualidade da FGV-EAESP. Disponível em: $<$ http://www.fgvsp.br/>. Acesso em: 21 Fev. 2004.

GAITHER, Norman; FRAZIER, Greg. Administração da produção e operações. $8^{\mathrm{a}}$ Ed. São Paulo: Pioneira-Thomson, 2002.

GODOY, Arilda S.; SILVA, Dirceu; ANCHIETA, José O. B.; MARIZ, Maria E. A. Preferências de Ensino; estudo exploratório com alunos de um curso superior de Administração de Empresas. Administração on line. Vol. 2, $\mathrm{N}^{\mathrm{o}}$ 3. julho-setembro 2001. São Paulo: Revista eletrônica da FECAP. Disponível em: $<$ http://www.fecap.br/adm online/adol/artigo.htm>. Acesso em: 05 fev. 2003.

GOETZ, Billy E. Teaching production management. Academy of Management Journal. Abril 1959; Vol. 2, No 1, p. $7-20$. 
GOFFIN, Keith. Operations management teaching on European MBA programmes. International Journal of Operations \& Production Management, Vol. 18, № 5, 1998, p. $424-451$.

GREENE, James H. (ed.) Production and inventory control handbook: prepared under supervision of the handbook editorial board of the American Production and Inventory control society (APICS). $3^{\text {rd }}$ ed. USA: McGraw-Hill,1997.

GROSSMAN JR., Thomas A. Student consulting projects benefit faculty and industry. Interfaces. Vol 32, $\mathrm{N}^{\mathrm{o}}$ 2, Março-Abril de 2002, p. 42 - 48.

GUIA do estudante. Melhores cursos e universidades. Ed. 3. São Paulo: Ed. Abril, 2004.

HAHN, Chan K.; PINTO, Peter A.; MABERT, Vincent; BIGGS, Joseph R. A profile of undergraduate educational programs in production and inventory management. Production and Inventory Management. Vol 23, $N^{\mathrm{o}} 3,3^{\text {rd }}$ Quarter 1982, p. 48 - 66.

HAHN, Chan K.; PINTO, Peter A.; MABERT, Vincent; BIGGS, Joseph R. Undergraduate Curriculum Design for Production/Operations Management. Production and Inventory Management. Vol 25, No 3, $3^{\text {rd }}$ Quarter 1984, p. $79-91$.

HANNA, Mark D.; NEWMAN, William. R. Integrated operations management: adding value for customers. $1^{\text {st }}$ ed. New Jersey: Prentice-Hall, Inc., 2001.

HEIZER, Jay; RENDER, Barry. Operations management. $5^{\text {th }}$ Ed. USA: Prentice-Hall, Inc., 1999.

HILL, T. J. Teaching manufacturing strategy. International Journal of Operations \& Production Management, Vol. 6, № 3, 1986, p. $10-20$.

HOUSHYAR, Abdolazim. Teaching manufacturing strategy. International Journal of Operations \& Production Management, Vol. 6, № 3, 1990, p. $10-20$.

INEP - Ministério da Educação. Manual de avaliação do curso de Administração. 2002. Disponível em: <http://www.inep.gov.br/download/superior/2002/condicoes_ensino/ACEADMINISTRACAO.pdf>. Acesso em: 22 mar. 2003.

INEP - Ministério da Educação. Sinópses estatísticas da educação superior. Disponível em: $<$ http://www.inep.gov.br/superior/censosuperior/sinopse/default.asp $>$. Acesso em: 21 fev. 2004a.

INEP - Ministério da Educação. Download de Provas, Gabaritos, Padrões de Resposta do Provão e Tabelas de Especificação de Habilidades e Conteúdos - Curso: Administração. Disponível em: <http://www.inep.gov.br/superior/provao/ gab_prov_pad_res/administracao.htm>. Acesso em: 21 fev. 2004b.

INEP - Ministério da Educação. Consulta aos resultados do ENC-Provão (1996 - 2003).

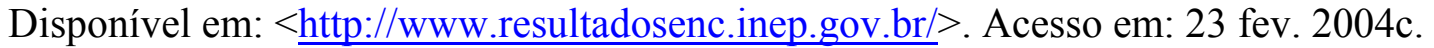


INEP - Ministério da Educação. Consulta aos resultados do ENC-Provão (1996 - 2003): Informações sobre os docentes. Disponível em: $<\underline{\mathrm{http}}$ ://www.resultadosenc. inep.gov.br/>. Acesso em: 30 mar. 2004d.

KRAJEWSKI, Lee J.; RITZMAN, Larry P. Operations management: strategy and analysis. $6^{\text {th }}$ ed. New Jersey: Prentice Hall (Pearson Education, Inc.), 2002.

KREUZ, Mauro. A importância da ANGRAD para o ensino da graduação em Administração no Brasil. ANGRAD, 2003. Disponível em: < $\underline{\text { http://angrad.com/>. }}$. Acesso em: 04 fev. 2004.

LUQUE, Rafaela A.; MACHUCA, José A. D. An empirical study of POM teaching in Spanish universities (II): faculty profile, teaching and assessment methods. International Journal of Operations \& Production Management, Vol. 23, No 4, 2003, p. $375-400$.

MACHLINE, Claude. Evolução da Administração da Produção no Brasil. Revista de Administração de Empresas. 1994, Vol. 34, No 3, p. 91-101. (apud WOOD JR., 2001).

MACHUCA, José A. D. POM facing the new millennium. International Journal of Operations \& Production Management, Vol. 23, No 1, 2003, p. 6 - 14.

MACHUCA, José A. D.; LUQUE, Rafaela A. An empirical study of POM teaching in Spanish universities (I): Content of POM courses. International Journal of Operations \& Production Management, Vol. 23, No 1, 2003, p. 15 - 43.

MACHUCA, José A. D.; ZAMORA, Maria M. G.; CASTILLO, José C. R. Filling some gaps in POM teaching and research. POM facing the new millennium: evaluating the past, leading with the present and planning the future of Operations-Selected papers from the First World Conference on POM. Sevilla, 2000 p. 117 - 130.

MARTINICH, Joseph S. Production and operations management: an applied modern approach. USA: John Wiley \& Sons, Inc, 1997.

MARTINS, G. A.; DELATORRE, R. M. Avaliação dos professores pelos alunos de graduação: o caso do Departamento de Administração da FEA/USP.. In Seminários em Administração - SEMEAD IV, Anais. São Paulo: Faculdade de Economia, Administração e Contabilidade da Universidade de São Paulo, 1999. (apud BIROCHI, 2000).

MARTINS, Petrônio G.; LAUGENI, Fernando P. Administração da produção. São Paulo: Saraiva, 1998.

MELNYK, Steven A.; DENZLER, David R. Operations management: a value-driven approach. USA: Mc-Graw Hill, 1996.

MEREDITH, Jack; ROTH, Aleda. Operations management in the USA. International Journal of Operations \& Production Management, Vol. 18, No 7, 1998, p. 668 - 674. 
MEREDITH, Jack R.; SHAFER, Scott M. Administração da produção para MBA's. Porto Alegre: Bookman Editora, 2002.

MERRIAM, Sharan B. Case study research in education: a qualitative approach. USA: Jossey-Bass Publishers, 1988.

MONKS, Joseph G. Administração da produção. São Paulo: McGraw-Hill, 1987.

MONTEIRO, Marcelo F. O currículo universitário frente a mudanças na sociedade: análise da evolução do currículo do curso de administração de empresas em nível de graduação da Faculdade de Economia e Administração da Universidade de São Paulo. Administração on line. Vol. 1, No 3. julho-setembro de 2000. São Paulo: Revista eletrônica da FECAP. Disponível em: < $\underline{\text { http://www.fecap.br/adm online/adol/artigo. }}$

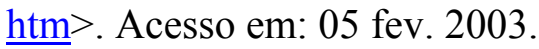

MOREIRA, Daniel Augusto (org.). Didática do ensino superior: técnicas e tendências. São Paulo: Pioneira, 1997.

MOREIRA, Daniel Augusto. Tendências do ensino de Administração da Produção e Operações: sugestões para professores e pesquisadores. Revista Álvares Penteado. V. 1, No 3, 1999, p. $87-112$.

MOREIRA, Daniel Augusto. Administração da produção e operações. São Paulo: Pioneira, 2000. (6 $6^{\text {a }}$ reimpressão do original de 1993).

MOREIRA, Daniel Augusto. O método fenomenológico na pesquisa. São Paulo: PioneiraThomson, 2002.

MOREIRA, Daniel A.; SILVA, Carlos E. M. Dificuldades percebidas na disciplina de Administração da Produção por alunos da $3^{\mathrm{a}}$ série de um curso de Administração de empresas: uma abordagem exploratória. Administração on line. Vol. 2, $\mathrm{N}^{\mathrm{o}} 1$. janeiromarço de 2001. São Paulo: Revista eletrônica da FECAP. Disponível em: $<$ http://www.fecap.br/adm_online/adol/artigo.htm>. Acesso em: 05 fev. 2003.

MORGAN, Catherine L. Achieving academic and practitioner objectives in the basic POM survey course. Production And Inventory Management Journal, Alexandria; Second Quarter; Vol. 30, No 2, 1989, p. 48 - 51.

MORRIS, John S. A new approach to teaching production operations management in the business core curriculum. Production And Inventory Management Journal, Falls Church; Second Quarter; Vol. 38, Nº 2, 1997, p. $42-46$.

MORTON, Thomas E. Production and operations management. Ohio: South-western College Publishing, 1999.

NAHMIAS, Steven. Production and operations analysis. $4^{\text {th }}$ ed. New York: McGraw-Hill, 2001.

PATTON, Michael Quinn. Qualitative evaluation and research methods. $2^{\mathrm{a}}$ Ed. USA: SAGE Publications, Inc, 1990. 
PILÃO, Nivaldo E. As disciplinas de administração da produção: nos cursos superiores de administração de empresas ministrados na grande São Paulo. Dissertação de mestrado. Escola de Administração de Empresas de São Paulo, FGV, São Paulo, 1987.

PROFETA, Rogério A. Administração da produção: docência aplicada. In Simpósio de Administração da Produção, Logística e Operações Internacionais - SIMPOI, III Anais. São Paulo: Fundação Getúlio Vargas, 2000. (CD-ROM).

PUTVINSKIS, Reinaldo. Análise da disciplina "Estatística" no curso de Administração de Empresas. Dissertação de mestrado. Faculdade de Ciências Econômicas de São Paulo da Fundação Escola de Comércio Álvares Penteado, São Paulo. 2001.

QUEIROZ, Abelardo A.; LUCERO, Adrián G.; BORGES, João C. C. M. O jogo da produção: uma ferramenta complementar ao ensino em engenharia de sistemas de produção. In $1^{\circ}$ COBEF - Congresso Brasileiro de Engenharia de Fabricação, promovido pela ABCM - Associação Brasileira de Ciências Mecânicas de 02 a 04 de abril de 2001. Disponível em: <http://www.geteq.ufsc.br/grupo/adrian/

COBEF2001b.pdf>. Acesso em: 05 fev. 2003. (Também disponível em CD-ROM).

RAISZADEH, Farhad M. E.; ETTKIN, Lawrence P. POM in academia: some causes for concern. Production And Inventory Management Journal, Second Quarter; Vol. 30, $\mathrm{N}^{\circ} 2,1989$, p. $37-40$.

REID, R. Dan; SANDERS, Nada R. Operations management. $3^{\text {rd }}$ ed. USA: John Wiley \& Sons, Inc., 2002.

RODRIGUES, Leandro. À procura de um estágio. Ensino superior. Dezembro, 2002, Ano 5, $\mathrm{N}^{\circ}$ 51, p. $10-15$.

RUSSEL, Roberta S.; TAYLOR III, Bernard W. Operations management. $4^{\text {th }}$ ed. New Jersey: Prentice Hall (Pearson Education, Inc.), 2003.

SANT'ANNA, Ilza M. Porque avaliar?: como avaliar?: critérios e instrumentos. $7^{a}$ Ed.. Rio de Janeiro: Vozes, 2001.

SANTI FILHO, Armando de. O ensino superior de administração no município de São Paulo. Dissertação de mestrado. Faculdade de Economia, Administração e Contabilidade. São Paulo: USP, 1981.

SCHROEDER, Roger G. Operations management: contemporary concepts. USA: McGraw-Hill, 2000.

SILVEIRA, Giovani J. C. Towards a framework for operations management in ecommerce. International Journal of Operations \& Production Management, 2003, Vol. 23, No 2, p. $200-212$.

SIMPOI. Anais do I Simpósio de Administração da Produção, Logística e Operações Internacionais. São Paulo: Fundação Getúlio Vargas, 1998. (1 Volume). 
SIMPOI. Anais do II Simpósio de Administração da Produção, Logística e Operações Internacionais. São Paulo: Fundação Getúlio Vargas, 1999. (2 Volumes).

SIMPOI. Anais do III Simpósio de Administração da Produção, Logística e Operações Internacionais. São Paulo: Fundação Getúlio Vargas, 2000. (CD-ROM).

SIMPOI. Anais do IV Simpósio de Administração da Produção, Logística e Operações Internacionais. São Paulo: Fundação Getúlio Vargas, 2001. (CD-ROM).

SIMPOI. Anais do V Simpósio de Administração da Produção, Logística e Operações Internacionais. São Paulo: Fundação Getúlio Vargas, 2002. (CD-ROM).

SLACK, Nigel; CHAMBERS, Stuart; HARLAND, Christine; et al. Administração da produção. $1^{a}$ Ed. São Paulo: Ed. Atlas, 1997.

SLACK, Nigel; CHAMBERS, Stuart; JOHNSTON, Robert. Administração da produção. $2^{a}$ Ed. São Paulo: Ed. Atlas, 2002.

SOHAL, Amrik S.; OAKLAND, John S. Teaching production and operations management through participative methods. Production And Inventory Management Journal, Third Quarter; Vol. 31, N 3, 1990, p. $30-34$.

STARR, Martin K. Pedagogical challenge: teaching international production and operations management courses. Production And Operations Management, Summer, Vol. 6, $\mathrm{N}^{\circ} 2,1997$, p. $114-123$.

STEVENSON, William J. Administração das operações de produção. $6^{\mathrm{a}} \mathrm{Ed}$. Rio de Janeiro: LTC, 2002.

TAJ, Shahram; HORMOZI, Amir M.; MIRSHAB, Bahman. Undergraduate academic teaching and manufacturing industry requirements: a comparative analysis. Interfaces. May - June, 1996; Vol. 26, No 3, p. 51 - 57.

TAKEI, Álvaro T. O ensino de disciplinas ligadas às teorias da Administração nos cursos superiores de Administração de Empresas no município de São Paulo. Dissertação de mestrado. Faculdade de Ciências Econômicas de São Paulo da Fundação Escola de Comércio Álvares Penteado, São Paulo, 2002.

TAKEI, Álvaro T.; NASCIMENTO, Paulo T. S.; PUTVINSKIS, Reinaldo. A avaliação de disciplinas nas instituições de ensino superior do município de São Paulo. Administração on line. Vol. 2, No 1. jan.--mar, 2001. São Paulo: Revista eletrônica da

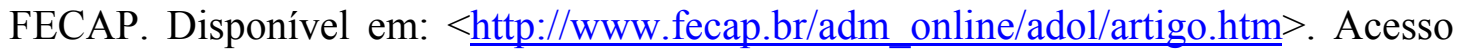
em: 05 fev. 2003.

TCHEOU, Hellen. Avaliação do ensino de Contabilidade nos cursos de Administração de Empresas na cidade de São Paulo. Dissertação de mestrado. Faculdade de Ciências Econômicas de São Paulo da Fundação Escola de Comércio Álvares Penteado, São Paulo, 2002. 
TEIXEIRA, Gilberto. O estado-da-arte da aprendizagem centrada no aluno em administração. Revista de Administração, São Paulo, v. 20, n. 2 p. 56 - 62, abr./jun, 1985.

TURATO, Egberto R. Tratado da metodologia da pesquisa clínico-qualitativa: construção teórico-epistemológica, discussão comparada e aplicação nas áreas de saúde e humanas. Rio de Janeiro: Editora Vozes, 2003.

VASCONCELLOS, E. P. G.; MATTAR, F. N. Avaliação do ensino de Administração: Modelo conceitual e aplicação. In Seminários em Administração - SEMEAD III, Anais. São Paulo: Faculdade de Economia, Administração e Contabilidade da Universidade de São Paulo, 1998. (apud BIROCHI, 2000).

WOLCOTT, Harry F. Writing up qualitative research. USA: SAGE Publications, 1990.

WOOD JR., Thomaz. Reformando o ensino e o aprendizado de gestão da produção e operações. In simpósio de Administração da Produção, Logística e Operações internacionais -SIMPOI, III Anais. São Paulo: Fundação Getúlio Vargas, 2000. (CDROM).

WOOD JR., Thomaz. Teaching and learning production and operations management: the journey from identy crisis to a cross-disciplinary approach. RAE: Revista de Administração de Empresas, São Paulo, v. 41, n. 1, jan/mar 2001, p. 67 - 75, jan./mar.

YIN, Robert K. Estudo de caso: planejamento e métodos. 2 $2^{\mathrm{a}}$ Ed. Porto Alegre: Bookman, 2001. (original de 1994). 
GLOSSÁRIO e ABREVIATURAS 


\section{GLOSSÁRIO e ABREVIATURAS}

AACSB: É uma associação sem fins lucrativos, criada em 1916 por algumas das mais importantes escolas de negócio americanas como American Assembly of Collegiate Schools of Business, sendo designada atualmente como The Association to Advance Collegiate School of Business. A AACSB estimula a excelência no ensino da Administração de Empresas através da certificação de cursos e incentivo a intercâmbios internacionais, contatos na área de negócios, discussão das melhores práticas, desenvolvimento profissional e outros serviços. (AACSB on line, 2004b; FEA-USP on line, 2004).

APO: Neste trabalho esta sigla foi usada para designar a Administração da Produção e Operações (Production \& Operations Management - POM), não deve ser confundida com a Administração por Objetivos, que é usual em alguns livros de Teoria Geral da Administração, como por exemplo em Ferreira et al (1997, p. 107). A APO utiliza algumas técnicas matemáticas do campo da Pesquisa Operacional (OR/MS - Operational Research - Management Science), como programação linear, teoria das filas e simulação, mas devemos observar que são campos distintos. Na APO são tratados vários conceitos, por exemplo:

- Projeto de produtos e serviços

- Projeto da rede de operações produtivas

- Arranjo físico e fluxo

- Tecnologia de processo

- Projeto e organização do trabalho

- Planejamento e controle de capacidade

- Planejamento e controle de estoque

- Planejamento e controle da cadeia de suprimentos

- MRP

- Just-In-Time

- Planejamento e controle de qualidade 
APICS: Entidade americana fundada em 1957 como American Production and Inventory Control Society, apesar de ter mantido a sigla original, seu nome foi alterado para The Educational Society for Resource Management, como uma forma de mostrar a expansão que houve em seu foco, incluindo vários programas e materiais para educação individual e organizacional (APICS on line, 2004). Ver também CPIM.

CAD: Projeto auxiliado por computador (Computer-Aided Design). O CAD permite o uso de simulações de produtos em computador, podendo fazer testes, criação e modificação dos desenhos (SLACK et al., 1997, p. 167 - 169).

CAM: Manufatura Assistida por Computador (Computer-Aided Manufacturing). A tecnologia do computador é utilizada para o planejamento e controle da produção

CEP: Controle Estatístico do Processo: Utilização de um conjunto de ferramentas estatísticas para avaliar e melhorar a qualidade de processos, produtos e serviços, normalmente são utilizados gráficos de controle para o monitoramento da tendência central e da dispersão evitando que os processos ou produtos se afastem das tolerâncias aceitáveis.

CFA: Conselho Federal de Administração.

CIM: Manufatura Integrada por Computador (Computer-Integred Manufacturing). Integra as tecnologias de FMS, de CAD/CAM e de gerenciamento (carregamento, programação e monitoração) (SLACK et al., 1997, p. 261 - 264).

CPIM: Certified in Production and Inventory Management. Este programa foi desenvolvido pela APICS em 1973 para a certificação profissional. Após sua reconfiguração no ano 2000, passou a ser composto por cinco módulos:

- Fundamentos da gestão da cadeia de suprimentos:

- Elementos da cadeia de suprimentos

- JIT

- Gestão da Qualidade Total

- MRP II

- Planejamento da demanda

- Gestão da capacidade

- Plano Mestre:

- Gestão da demanda 
- Planejamento de vendas e operações

- Plano mestre

- Medidas do Plano de Negócios

- Planejamento e programação detalhada:

- Técnicas e práticas da gestão de estoques

- Planejamento detalhado de materiais

- Planejamento de operações para dar suporte ao plano de prioridades

- Planejamento de necessidades e fontes externas de suprimentos

- Execução e controle das operações:

- Priorização e sequenciamento do trabalho

- Execução dos planos e implementação de controles

- Autorização e registro de atividades para os sistemas de empurrar ou puxar

- Avaliação do desempenho e feedback.

- Gestão estratégica de recursos:

- Tópicos sobre mercado competitivo

- Decisões que afetam a empresa, a cadeia de suprimentos, a tecnologia de informação e o projeto organizacional

- Configuração e integração dos processos internos

- Avaliação e gestão de projetos

CRA: Conselho Regional de Administração.

DIRETRIZES CURRICULARES NACIONAIS: O Parecer CNE/CES 0067/2003 apresenta a evolução da legislação relacionada ao Ensino Superior e finaliza descrevendo o objetivo que se tem buscado:

[...] foi concebido com o propósito de que se pudesse estabelecer um perfil do formando no qual a formação de nível superior se constituísse em processo contínuo, autônomo e permanente, com uma sólida formação básica e uma formação profissional fundamentada na competência teórico-prática, observada a flexibilização curricular, autonomia e a liberdade das instituições de inovar seus projetos pedagógicos de graduação, para o atendimento das contínuas e emergentes mudanças para cujo desafio o futuro formando deverá estar apto. (BRASIL on line, 2003a). 
FMS: Sistema flexível de manufatura (Flexible Manufacturing Systems). É um sistema que integra tecnologias de manufatura auxiliada por computador e de manuseio. Um sistema central de controle por computador coordena as atividades das estações de trabalho (máquinas-ferramenta de controle numérico), instalações de carga e descarga, transporte e manuseio entre as estações de trabalho (esteiras, trilhos, robôs, etc.) (SLACK et al., 1997, p. $258-264)$.

IDM: Administração industrial (Industrial Management).

IES: Instituição de Ensino Superior, podendo ser públicas ou privadas, com variados graus de abrangência ou especialização, como por exemplo: universidades, centros universitários, faculdades integradas, faculdades, institutos superiores, escolas superiores ou centros de educação tecnológica.

INEP: Instituto Nacional de Estudos e Pesquisas Educacionais.

JIT: Just-In-Time.

MRP: Planejamento das necessidades de material (Material Requirements Planning).

MRP II: Planejamento dos recursos de manufatura (Manufacturing Resource Planning).

OM: Administração de Operações (Operations Management) (ver APO).

PCP: Planejamento e Controle da Produção

PERT/CPM: Técnica de Revisão e Avaliação de Programa (PERT-Program Evaluation and Review Technique) e Método do Caminho Crítico (CPM-Critical Path Method).

POM: Administração da Produção e de Operações (Production and Operations Management) (ver APO). 
P \& IM: Administração da produção e estoques (Production and Inventory Management). Expressão usada por alguns autores com o mesmo significado de POM, por exemplo: HAHN et al (1984).

PIM: Mesmo que P \& IM

OR/MS: Pesquisa Operacional (Operational Research and Management Science) (ver comentários em APO).

TPM: Manutenção Produtiva Total. Visa eliminar a variabilidade dos processos produtivos causada pelas quebras, o que é alcançado através do incentivo aos funcionários em assumir a responsabilidade por suas máquinas e a executar atividades rotineiras de manutenção e reparos simples (SLACK et al, 1997, p. 483).

TQM: Gestão da Qualidade Total (Total Quality Management). 
APÊNDICE 


\section{APÊNDICE A - Diretrizes curriculares ${ }^{15}$}

\section{- Perfil Desejado do Formando}

O curso de Administração deve ensejar condições para que o bacharel em Administração esteja capacitado a compreender as questões científicas, técnicas, sociais e econômicas da produção e de seu gerenciamento no seu conjunto, observados os níveis graduais do processo de tomada de decisão, bem como a desenvolver o alto gerenciamento e a assimilação de novas informações, apresentando flexibilidade intelectual e adaptabilidade contextualizada no trato de situações diversas presentes ou emergentes nos vários segmentos do campo de atuação do administrador. [...]

\section{- Competências e Habilidades}

Os cursos de graduação de Administração devem formar profissionais que revelem, pelo menos, as seguintes competências e habilidades:

- reconhecer e definir problemas, equacionar soluções, pensar estrategicamente, introduzir modificações no processo produtivo, atuar preventivamente, transferir e generalizar conhecimentos e exercer, em diferentes graus de complexidade, o processo da tomada de decisão;

- $\quad[\ldots]$;

- refletir e atuar criticamente sobre a esfera da producão, compreendendo sua posição e função na estrutura produtiva sob seu controle e gerenciamento;

- desenvolver raciocínio lógico, crítico e analítico para operar com valores e formulações matemáticas presentes nas relações formais e causais entre fenômenos produtivos, administrativos e de controle, bem assim expressandose de modo crítico e criativo diante dos diferentes contextos organizacionais e sociais;

- ter iniciativa, criatividade, determinação, vontade política e administrativa, vontade de aprender, abertura às mudanças e consciência da qualidade e das implicações éticas do seu exercício profissional; [...].

\section{- Conteúdos Curriculares}

\footnotetext{
15 Este texto corresponde ao parecer CNE/CES 0134/2003 (BRASIL on line, 2003b) e foi sublinhado para destacar os tópicos relacionados à APO. No momento dessa análise era o documento mais atual, mas também foram analisados os pareceres CNE/CES 0146/2002 e CNE/CES 0067/2003 (BRASIL on line, 2002; 2003a).
} 
Os cursos de graduação em Administração deverão contemplar, em seus projetos pedagógicos e em sua organização curricular, conteúdos que revelem Interrelações com a realidade nacional e internacional, segundo uma perspectiva histórica e contextualizada de sua aplicabilidade no âmbito das organizações e do meio através da utilização de tecnologias inovadoras e que atendam aos seguintes campos interligados de formação:

I - Conteúdos de Formação Básica: relacionados com estudos antropológicos, sociológicos, filosóficos, psicológicos, ético-profissionais, políticos, comportamentais, econômicos e contábeis, bem como os relacionados com as tecnologias da comunicação e da informação e das ciências jurídicas;

II - Conteúdos de Formação Profissional: relacionados com as áreas específicas, envolvendo teorias da administração e das organizações e a administração de recursos humanos, mercado e marketing, materiais, producão e logística, financeira e orçamentária, sistemas de informações, planejamento estratégico e serviços; ${ }^{16}$

III - Conteúdos de Estudos Quantitativos e suas Tecnologias: abrangendo pesquisa operacional, teoria dos jogos, modelos matemáticos e estatísticos e aplicação de tecnologias que contribuam para a definição e utilização de estratégias e procedimentos inerentes à administração; e

IV - Conteúdos de Formação Complementar: estudos opcionais de caráter transversal e interdisciplinar para o enriquecimento do perfil do formando.

16 O parecer CNE/CES 0067/2003 era mais genérico ainda: "Estudos da Teoria da Administração e das organizações e suas respectivas funções [...].” (BRASIL on line, 2003a). 


\section{APÊNDICE B - E-mail enviado aos professores de APO na graduação}

Caro Professor(a),

Neste momento estou terminando minha tese na FEA-USP, que trata do ensino de Administração da Produção e Operações (APO) e meu orientador é o professor Daniel Augusto Moreira.

O trabalho é composto por quatro partes, na primeira foi feita a revisão da literatura (identificar o estado-da-arte), na segunda uma análise do conteúdo dos livros didáticos de APO (8 nacionais ou traduzidos e 10 americanos), na terceira foram analisadas as questões do Provão e neste momento estou analisando os programas e estruturas dos cursos da FEAPUC-SP, FEA-USP e FGV-EAESP, por isso, a sua opinião é muito importante para que o resultado deste trabalho seja o mais correto possível.

Já recebi algumas informações (plano de ensino e grade de disciplinas), mas neste momento eu gostaria de saber a sua opinião sobre as cinco questões anexas.

Agradeço desde já a sua gentileza.

\section{Diógenes de Souza Bido}

$\mathrm{N}^{\mathrm{o}}$ USP 461415

Rua Juan Vicente, 377 - Bloco 12 - Apto 113

Osasco - SP - 06160-180

Res. 3691.3828 - Cel 8204.9908

bido@,ig.com.br 
1) Quais os recursos que o $\operatorname{Sr}(a)$. tem utilizado em sua aula?

\begin{tabular}{|l|l|l|l|}
\hline \multicolumn{1}{|c|}{$\begin{array}{c}\text { Recurso e método de } \\
\text { ensino }\end{array}$} & $\begin{array}{c}\text { Usou em } \\
\mathbf{2 0 0 3} \\
(\mathbf{s} / \mathbf{n})\end{array}$ & $\begin{array}{c}\text { Pretende } \\
\text { usar em } \\
\mathbf{2 0 0 4}(\mathbf{s} / \mathbf{n})\end{array}$ & Exemplo \\
\hline Retro-projetor & & & \\
\hline Multimídia (canhão) & & & \\
\hline Filmes & & & \\
\hline $\begin{array}{l}\text { Simulação e jogos sem o } \\
\text { uso de computador }\end{array}$ & & & \\
\hline $\begin{array}{l}\text { Simulação e jogos com uso } \\
\text { de computador }\end{array}$ & & & \\
\hline Casos & & & \\
\hline Palestras de profissionais & & & \\
\hline $\begin{array}{l}\text { Seminários (discussão de } \\
\text { trabalhos dos alunos) }\end{array}$ & & & \\
\hline $\begin{array}{l}\text { Visitas (alunos nas } \\
\text { empresas) }\end{array}$ & & & \\
\hline Aulas expositivas & & & \\
\hline Outros & & & \\
\hline
\end{tabular}

2) Como o $\operatorname{Sr}(a)$. tem feito a avaliação do processo ensino-aprendizagem? (professor avaliando o aluno)

3) É feito algum tipo de trabalho com o objetivo de integrar as disciplinas de APO com as demais disciplinas do curso? Em caso afirmativo, como é feito?

4) O Provão influenciou de alguma forma (conteúdo, método de ensino ou de avaliação) a disciplina que o $\operatorname{Sr}(a)$. tem ministrado no curso de graduação desta escola?

5) Para o $\operatorname{Sr}(a)$, o que mais distingue o curso de graduação em Administração de Empresas da FEAPUC-SP, FEA-USP e FGV-EAESP ? $^{17}$

\footnotetext{
17 Percebemos que a questão estava com duplo sentido somente na análise das respostas, isto é, o primeiro sentido seria "o que distingue essas três escolas das demais?" e o segundo sentido: "o que distingue uma da outra?". Apesar disso, o resultado foi positivo porque acabou trazendo mais informações para análise e estimulando novos contatos, o que é típico da pesquisa qualitativa.
} 


\section{APÊNDICE C - Credibilidade do pesquisador}

O autor desta pesquisa foi o responsável pelo levantamento de dados e pelas análises, não havendo a participação de pesquisadores auxiliares.

\section{Formação:}

- Doutorando (início em janeiro de 2000)

- Mestrado em Administração na FEA-USP no período de janeiro de 1995 a agosto de 1999.

- Especialização em Marketing na FAC-FITO no período de 14 de agosto de 1996 a 25 de setembro de 1997, com duração de 396 horas.

- Especialização em Administração econômico-financeira na FAC-FITO no período de 14 de março de 1994 a 25 de abril de 1995, com duração de 396 horas.

- Especialização em Engenharia da Qualidade na FDTE-USP (atual PECE) no período de maio de 1992 a dezembro de 1994, com duração de 420 horas.

- Graduação em Engenharia Química na Escola Superior de Química Oswaldo Cruz no período de 1986 a 1991.

\section{Experiência com o tema:}

- Tem sido professor universitário desde março de 1993, lecionando disciplinas ligadas principalmente à matemática. Vale ressaltar a disciplina Programação Linear para as turmas de $3^{\circ}, 4^{\circ}$ e $5^{\circ}$ anos de graduação em Economia.

- No primeiro semestre de 2001 lecionou parte da disciplina Gestão da Qualidade e Produtividade (EAD-465) para a turma de último ano da graduação em Administração na FEA-USP pelo Programa de Aperfeiçoamento do Ensino (PAE), sob supervisão do Prof. Dr. Paulo Tromboni de Souza Nascimento.

- No primeiro semestre de 2001 lecionou a disciplina Sistemas da Qualidade no curso de pós-graduação lato sensu Gestão da Qualidade e Inovação de Produtos do Mackenzie.

- No mesmo semestre, em outra IES, lecionou a mesma disciplina para uma turma de $1^{\mathrm{o}}$ ano de graduação em Administração de Empresas, sendo uma experiência de insucesso. Como tinha sido comentado na seção 2.1.1.

- Ministrou três aulas-palestra sobre "Gestão da Qualidade" no curso de Especialização em Papel e Celulose da USP nos dias 15 e 16 de março de 2002 e 29 de março de 2003.

- Cursou diversas disciplinas ligadas à Administração da Produção e Operações durante o mestrado e doutorado, tanto na FEA-USP quanto na engenharia de Produção da Escola Politécnica da USP.

- Desde maio de 1997 tem atuado em tempo parcial como consultor na implementação e manutenção de sistemas de gestão da qualidade (ISO 9000). 


\section{Treinamento para a pesquisa qualitativa:}

- Além das três disciplinas de Metodologia da Pesquisa que são obrigatórias nos cursos de mestrado e doutorado da FEA-USP, também cursou a disciplina Metodologia da Pesquisa Qualitativa oferecida na ECA-USP no período de 13 de março de 2000 a 30 de agosto de 2000.

- No período de novembro de 2002 a janeiro de 2003 releu alguns livros sobre metodologia, como: Merriam (1988), Moreira (2002), Patton (1990), Wolcott (1990) e Yin (2001). No período de junho a julho de 2003 reforçou o treinamento no método através da leitura de Turato (2003), que destacou a importância:

$\circ \quad$ dos aspectos emocionais envolvidos na entrevista (p. 112); ${ }^{18}$

- de pensar a ciência e conhecer a sua história (como formação do pesquisador) através da leitura de autores como: Karl R. Popper, Thomas S. Kuhn, Imre Lakatos, Paul K. Feyerabend entre outros (p. 116);

- da leitura da bibliografia relacionada às metodologias qualitativas em geral, destacando: Norman K. Denzin, Robert C. Bogdan e Sari K. Biklen (p.109).

\section{Experiência com o método de pesquisa:}

- $\mathrm{Na}$ dissertação de mestrado desenvolveu oito estudos de caso com resultado bastante satisfatório (BIDO, 1999).

- Desenvolveu um trabalho de conclusão de curso (não publicado) para a disciplina Metodologia da Pesquisa Qualitativa.

- Participou do Programa de Capacitação de Avaliadores para a Avaliação das Condições de Ensino dos Cursos de Graduação de Administração, que foi realizado em Brasília nos dias 07 e 08 de maio de 2002 pelo INEP/MEC, tendo realizado quatro avaliações no ano de 2003.

- Apesar de ter um objetivo totalmente diferente, o processo de auditoria de sistemas de gestão da qualidade se utiliza de muitas ferramentas da pesquisa qualitativa. $\mathrm{O}$ autor tem feito auditorias em empresas do ramo metalúrgico e elétrico, além de ministrar cursos de formação de auditores internos, dando ênfase aos métodos de coleta de dados utilizando múltiplas fontes de evidências. Tendo as seguintes certificações profissionais ${ }^{19}$ :

- Certified Quality Auditor pela American Society for Quality em 04 de dezembro de 1999, recertificado em 09 de dezembro de 2002.

- Requalificação de auditores-líderes da qualidade com certificado reconhecido pelo IQA/IRCA (Institute for Quality Assurance / International Register of Certificated Auditors) do Reino Unido (curso de 16 horas no período de 20 a 21 de março de 2001 - qualificação inicial em outubro de 1997).

- Instrutor para o curso de Lead Assessor com certificado reconhecido pelo IQA/IRCA e ASQ/RAB (American Society for Quality / Registrar Accreditation Board) dos EUA (curso de 38 horas no período de 03 a 06 de dezembro de 1998).

- Avaliador de Meios de Hospedagem com certificado reconhecido pelo INMETRO e EMBRATUR (curso de 40 horas no período de 27 a 31 de julho de 1998).

\section{Ligações pessoais e profissionais com as IES's que participaram da pesquisa:}

- FEA-USP: como aluno desde 1995.

\footnotetext{
18 O que é justificado, principalmente, por se tratar de um livro aplicado às áreas de saúde e humanas. Patton (1990, p. 134-141) apresenta exemplos em que a metodologia da pesquisa qualitativa é particularmente útil.
} 